\title{
Fossil lizards and worm lizards (Reptilia, Squamata) from the Neogene and Quaternary of Europe: an overview
}

\author{
Andrea Villa ${ }^{1}$ (D) Massimo Delfino ${ }^{1,2}$ (D) \\ Received: 16 August 2018/Accepted: 19 October 2018/Published online: 29 October 2018 \\ (C) Akademie der Naturwissenschaften Schweiz (SCNAT) 2018
}

\begin{abstract}
Lizards were and still are an important component of the European herpetofauna. The modern European lizard fauna started to set up in the Miocene and a rich fossil record is known from Neogene and Quaternary sites. At least 12 lizard and worm lizard families are represented in the European fossil record of the last $23 \mathrm{Ma}$. The record comprises more than 3000 occurrences from more than 800 localities, mainly of Miocene and Pleistocene age. By the beginning of the Neogene, a marked faunistic change is detectable compared to the lizard fossil record of Palaeogene Europe. This change is reflected by other squamates as well and might be related to an environmental deterioration occurring roughly at the Oligocene/ Miocene boundary. Nevertheless, the diversity was still rather high in the Neogene and started to decrease with the onset of the Quaternary glacial cycles. This led to the current impoverished lizard fauna, with the southward range shrinking of the most thermophilic taxa (e.g., agamids, amphisbaenians) and the local disappearance of other groups (e.g., varanids). Our overview of the known fossil record of European Neogene and Quaternary lizards and worm lizards highlighted a substantial number of either unpublished or poorly known occurrences often referred to wastebasket taxa. A proper study of these and other remains, as well as a better sampling of poorly explored time ranges (e.g., Pliocene, Holocene), is needed and would be of utmost importance to better understand the evolutionary history of these reptiles in Europe.
\end{abstract}

Keywords "Lacertilia" · Amphisbaenia · fossil record · Cenozoic

\section{Introduction}

Squamates are by far the most diverse group of reptiles currently living on Earth, including more than 10,000 extant species of lizards, snake and amphisbaenians (Uetz et al. 2018). They live on all continents but Antarctica and encompass a very high diversity in terms of both

Editorial Handling: M. R. Sánchez-Villagra.

Electronic supplementary material The online version of this article (https://doi.org/10.1007/s13358-018-0172-y) contains supplementary material, which is available to authorized users.

Andrea Villa

a.villa@unito.it

1 Dipartimento di Scienze della Terra, Università degli Studi di Torino, via Valperga Caluso 35, 10125 Torino, Italy

2 Institut Català de Paleontologia Miquel Crusafont, Universitat Autònoma de Barcelona, Edifici ICTA-ICP, Carrer de les Columnes s/n, Campus de la UAB, Cerdanyola del Vallès, 08193 Barcelona, Spain morphologies and occupied ecological niches. Among squamates, lizards account for more than 6000 of the living species in more than 30 families (Uetz et al. 2018). However, even though the monophyly of both amphisbaenians and snakes has been largely confirmed (among others, Conrad 2008; Hedges and Vidal 2009; Gauthier et al. 2012), this is not true for the lizard group, which is in fact paraphyletic.

In the recent past, molecular divergence estimates placed the separation between Squamata and their sister taxon, Rhynchocephalia, in the Early-Middle Triassic, and the origin of crown squamates in the Late Triassic-Early Jurassic (Jones et al. 2013; but see discussion and reference therein for previous different estimates). However, the origin of squamates was set at the late Permian by Simões et al. (2018), who reinterpreted Megachirella wachtleri Renesto and Posenato, 2003 from the Middle Triassic of the Italian Alps, Marmoretta oxoniensis Evans 1991 from the Middle Jurassic of Britain and Huehuecuetzpalli mixtecus Reynoso 1998 from the Early Cretaceous of Mexico as stem squamates. Fossils of rhynchocephalians are found 
since the Triassic (e.g., Swinton 1939; Fraser 1982; Whiteside 1986; Fraser and Benton 1989; Jones et al. 2013), but the oldest undisputed crown squamates known are only Middle Jurassic in age (Rage 2013). Thus, there is a large gap in our knowledge of the early evolutionary history of these reptiles. A possible occurrence of lizards from the Early Jurassic (Pliensbachian) of North America is mentioned by Meszoely et al. (1987), but this record cannot be confirmed due to absence of descriptions and figures of the specimens. Middle Jurassic squamates were found in Europe and maybe India (Rage 2013). The age of the Indian remains is uncertain: different authors dated the Kota Formation, from which they were collected, to different time ranges, extending from the Early Jurassic to the Early Cretaceous, and these fossils might, therefore, be either older or younger (Vijaya and Prasad 2001; Evans et al. 2002; Prasad and Manhas 2007; Mukhopadhyay et al. 2010). The European remains, on the other hand, come from a number of localities in England that are well dated to the Bathonian (Evans 1998; Evans and Milner 1994; Evans et al. 2006). These remains represent a fauna that is already diverse, including members of different lizard clades (Evans 1994, 1998; Evans et al. 2006; Rage 2013) and potentially crown snakes (Caldwell et al. 2015).

Lizards are, therefore, present in what is now the European continent since the beginning of what we know of their evolutionary history. They remained an important component of the European fauna since then, as is testified by the high number of fossils found on the continent documenting a wide variety of different morphologies and taxa (see e.g., Rage 2013 and reference therein). The modern European lizard fauna started to set up in the Neogene, with the first representatives of taxa closely related to modern ones appearing in the early Miocene (Čerňanský 2010b; Rage 2013; Čerňanský et al. 2015). Neogene and Quaternary fossils are, therefore, pivotal to understand the origin and evolution of the current lizard assemblage in Europe. They are also important because of their closer relationships with extant taxa if compared with Paleogene forms. Given that the distribution of reptiles is strongly tied to environmental factors (mainly temperature; Sears and Angilletta 2004; Vitt and Caldwell 2009), these fossils (Quaternary ones in particular, which are commonly referred to extant taxa) can help in understanding the environmental changes that occurred in the past by comparing their occurrences with the distribution of closely related extant taxa for which ecological requirements are known (among others, Böhme 2003; Agustí et al. 2009; Blain et al. 2009, 2013, 2014a, 2016; Villa et al. 2018a, b).

Lizard palaeontology in Europe dates back to at least the nineteenth century and numerous extinct species and fossil assemblages were described since then. However, these reptiles received far less attention on the whole than other groups of animals (mammals in particular) in the past. In many cases, they were either just overlooked or attributed to wastebasket taxa (see also below). For sure, this was at least partially due also to a scarce knowledge of the comparative osteology of extant lizards, which hindered a clear recognition of skeletal features potentially useful in the identification of fossils (Villa et al. 2017a). More recently, an increased interest in both the comparative osteology of European lizards (Villa et al. 2017a) and their fossil record resulted in a rise in the number of fossil lizard assemblages described. The European lizard fossil record was reviewed in the past as part of wider accounts that were not focused directly on them. The classic handbook of Estes (1983) was meant as an encyclopaedic treatment of the entire fossil record of lizards in the world. Though exhaustive for the time, the book is now outdated because of both advancements in lizard taxonomy and new palaeontological findings. More recently, lizards were also largely mentioned in the review of European fossil squamates by Rage (2013). Adding to these, recaps of the fossil record of particular groups are scattered in various papers (e.g., geckos in Daza et al. 2014; agamids in Delfino et al. 2008, and Blain et al. 2016; chamaeleons in Georgalis et al. 2016a). However, a detailed, updated and complete summary of the entire fossil record of lizards in Europe is still missing. To partly solve this issue, we here provide an overview of the Neogene and Quaternary component of this record. We summarize and discuss the fossil occurrences of each lizard group that was reported to have lived on the European continent during the last 23 million years. Worm lizards (Amphisbaenia) are also included, given that they are often treated together with lizards in palaeontological works.

\section{Materials and methods}

To have a clear and rapidly accessible database of the Neogene and Quaternary fossil occurrences of lizards and amphisbaenians in Europe, we created a catalogue gathering all records mentioned in the consulted literature (see Online Resources 1, 2, 3 and 4). The structure of this catalogue is based on the Italian Palaeoherpetological Database created by Delfino (1997a, 2002). Entries are represented by taxon/locality data (also known as SPLOC data: SPecies Locality OCcurences), that is each entry is defined by a taxon and the locality where such taxon has been found. Other information, such as the previous identifications of the taxon, the chronological data of the locality and the referred bibliography, were added, but, since the catalogue is conceived as a synthetic tool, additional information was kept to the essential points. The bibliographic references include all mentions of the related entry, being those in published papers, conference abstracts 
or online databases. Both published material and simple mentions were considered, since the exclusion of the latter might have resulted in the loss of useful information related to less studied areas as well as important taxonomic comments. It has to be noted, however, that unpublished reports must be taken with caution given that they cannot be easily verified and are, therefore, less reliable. This is the case, for example, for the unpublished records reported in the single database consulted for the creation of the catalogue: Böhme and Ilg's (2003) fosFARbase. Bachelor or Master degree theses were not considered because they have a very local distribution and are often difficult to access (in contrast to, e.g., PhD thesis, which have a wider distribution and are often deposited in public repositories). This is, therefore, mainly a practical issue, rather than being due to any intrinsic evaluation of this category of documents. The catalogue is composed of three parts, respectively, devoted to "Lacertilia", Amphisbaenia and to remains that have been previously attributed to lizards, but are now considered not to belong to such group. It has to be noted that the data included in the catalogue should not be considered separately from the related references, since only by consulting those references, it is possible to completely understand the real nature of the identifications and the possible affinities of the fossil material. This is particularly true for occurrences referred to extant species, the identification of which might sometimes be questionable. One of the main reasons that originate this issue is the trend to assign fossils from (usually) young localities to extant taxa based on a biogeographical criterion, assuming that the species that are currently present in the proximity of the site could also have been present there in not-so-older times. This, flanked with misidentifications due to poor osteological knowledge, might cause erroneous palaeobiogeographical reconstructions, such as in the case of the purported stability throughout the Pleistocene and Holocene of North American herpetofauna (Bell et al. 2010). The definition of Europe follows that of Arnold and Ovenden (2002), but excluding Madeira and the Canary Islands.

\section{Results}

Remains of Neogene and Quaternary lizards and amphisbaenians are rather common across Europe. To our best knowledge, 376 papers published since 1851 (Lartet 1851; see Fig. 1 for an account of the papers published per decade) describe or even only cite 3080 SPLOC data, distributed in more than 800 localities spanning from the early Miocene to the Holocene (Fig. 2). A large number of these data pertain to occurrences dated back to the Miocene, followed by the Pleistocene ones in terms of abundance

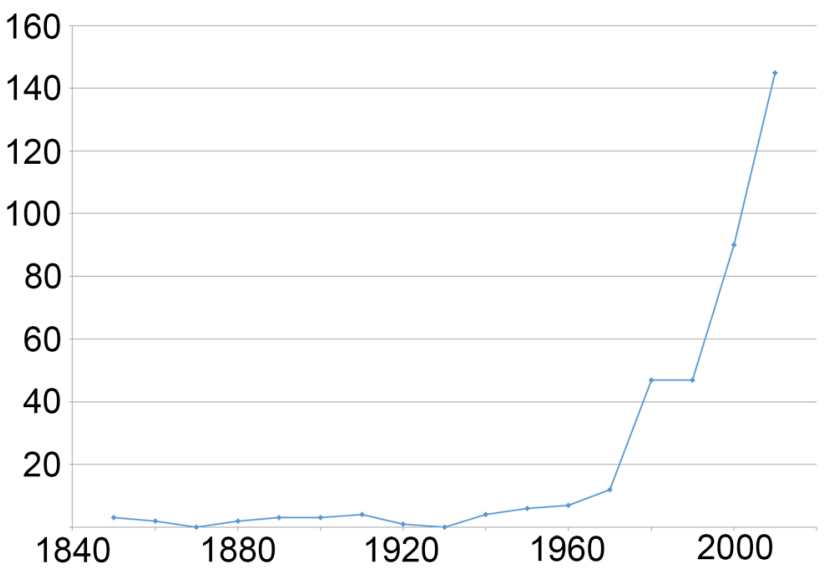

Fig. 1 Graph illustrating the number of papers about Neogene and Quaternary lizards and worm lizards (total number 376) published per decade since 1851. The current decade stops at the end of June 2018. Note that the numbers of papers published in the last 18 years significantly outnumber those published from 1851 to 1999 (1850: 3; 1860: 2; 1870: 0; 1880: 2; 1890: 3; 1900: 3; 1910: 4; 1920: 1; 1930: 0; 1940: 4; 1950: 6; 1960: 7; 1970: 12; 1980: 47; 1990: 47; 2000: 90; 2010: 145)

(Figs. 3, 4). Pliocene and in particular Holocene data are significantly less represented. At least 12 lizard and worm lizard families are represented in the Neogene and Quaternary fossil record of the continent, including both families that are still present in Europe nowadays and others that are now locally absent. Taxa with uncertain phylogenetic relationships are also reported.

\section{Agamidae}

In this paper, we follow the broad definition of Agamidae reported by Pyron et al. (2013), thus including Agaminae, Amphibolurinae, Draconinae, Hydrosaurinae, Leiolepidinae and Uromastycinae as subfamilies. Within the herein considered time period, fossil agamids (Fig. 5a-f) are reported in Europe since the early Miocene up to the Late Pleistocene, even though they are distinctly not as common as other groups of lizards living on the continent. In the past, the trend was to assign all agamid findings to the genus Agama in a wide sense (including also Laudakia and Stellagama), which led to numerous mentions of the genus across the continent. Even if some tentative attributions to Laudakia are also known (e.g., in Almenara Casablanca and Vallirana in Spain; Blain 2005, but later mentioned as Agamidae indet., as in, e.g., Blain 2009 and Blain et al. 2016), Delfino et al. (2008) underlined that the few characters used to discriminate Agama s.s. and Laudakia s.l. most probably originated from the study of limited comparative material and need to be checked on larger comparative samples before being considered valid. More recently, new characters useful to distinguish Laudakia, 


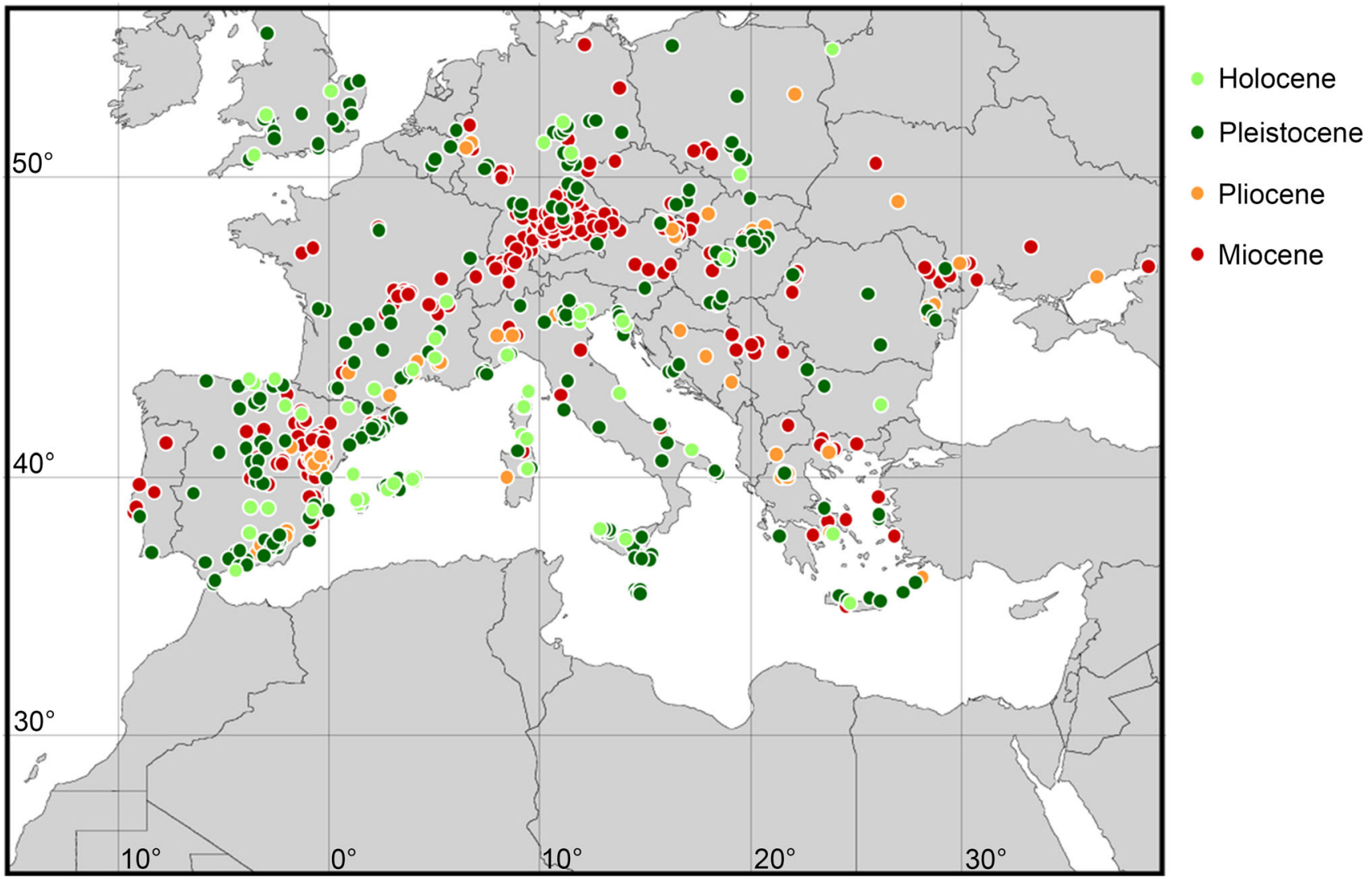

Fig. 2 Neogene and Quaternary fossil lizards occurrences in Europe

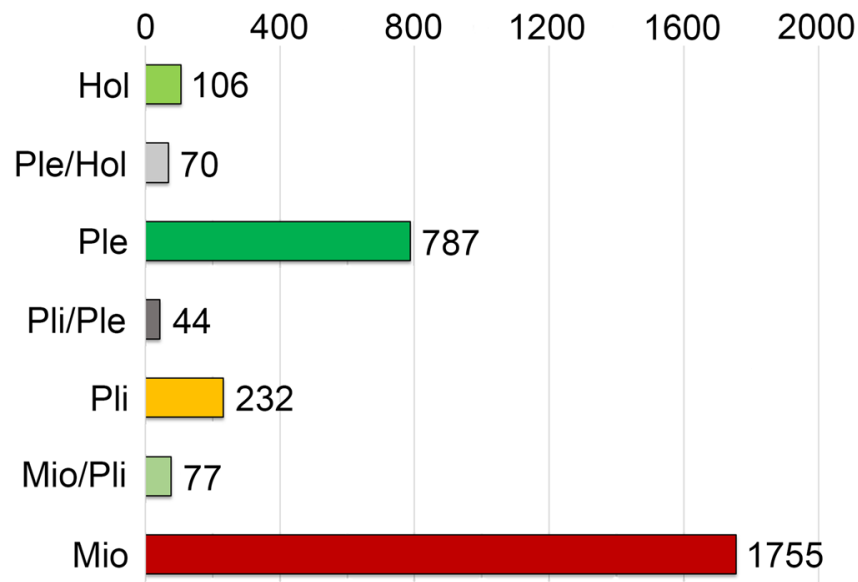

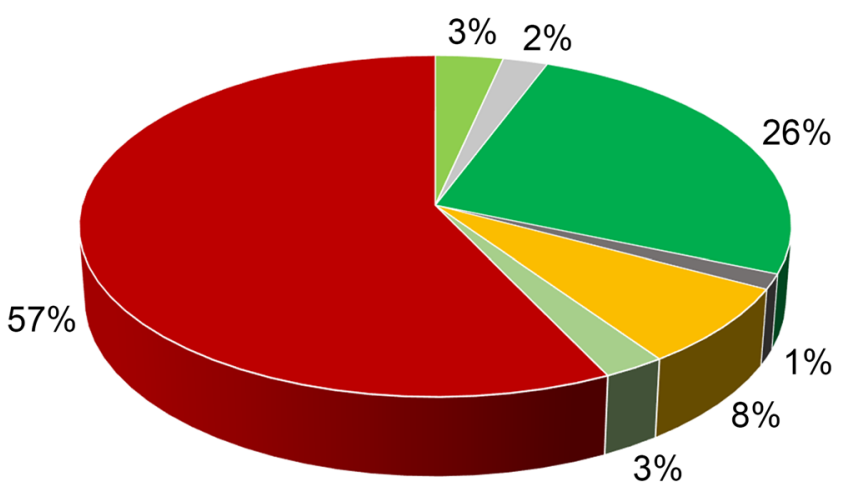

Fig. 3 Lizard occurrences by age in absolute numbers (left) and percentage (right). Occurrences from Canal Negre 1 and Punta Nati 3 and 12 are not included due to high uncertainty in their age

Paralaudakia and Stellagama were proposed by Smith et al. (2016). The wide sense with which the name Agama has been used might suggest that most of the European Neogene and Quaternary remains could be equally referred to as indeterminate members of the family Agamidae (or maybe sometimes even of the subfamily Agaminae), pending a thorough revision based on new osteological data. It has to be noted, however, that excluding attribution to some extant genera is sometimes possible, as is the case for example for the agamids from the Pleistocene of Monte Tuttavista, in Italy, which are clearly different from Phrynocephalus and Trapelus according to Delfino et al. (2008). The absence of detailed comparative studies of extant and fossil forms, as well as the preservational status 


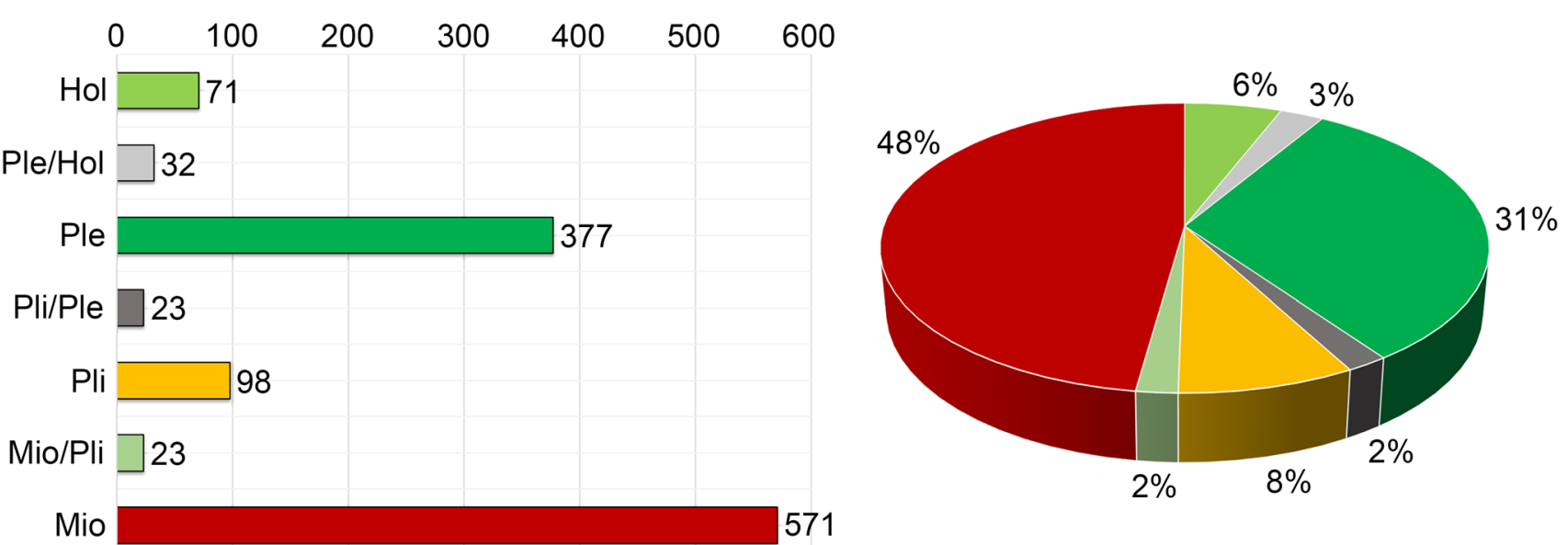

Fig. 4 Number of localities with fossil lizards by age in absolute numbers (left) and percentage (right). Canal Negre 1 and Punta Nati 3 and 12 are not included due to high uncertainty in their age
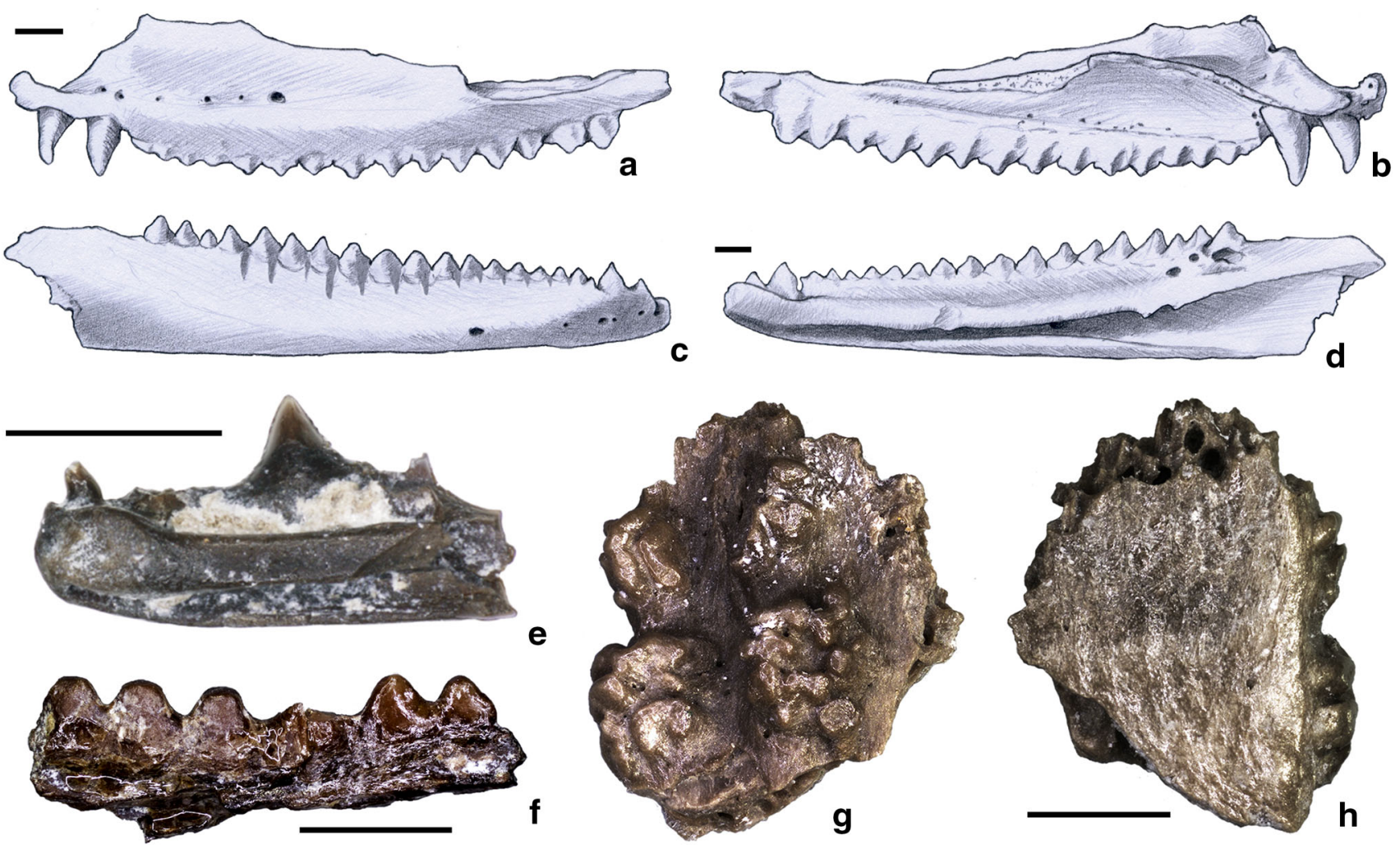

Fig. 5 Agamid and chamalaeonid remains from Europe: left maxilla (OR H VI 3/1; a-b) and right dentary (OR H VI 3/5; c-d) of Agama s.l. from Monte Tuttavista, Italy, in lateral (a, c) and medial (b, d) views (Delfino et al. 2008); right dentary (MGPT-PU 132081; e) of Agamidae indet. from Verduno, Italy, in medial view (Colombero

et al. 2014); tooth-bearing bone (MGPT-PU 132438; f) of Agamidae indet. from Moncucco Torinese, Italy, in lateral view (Colombero et al. 2017); skull roofing bone (UU AL 3501; $\mathbf{g - h}$ ) of Chamaeleo cf. C. andrusovi from Aliveri, Greece, in external (g) and internal (h) views (Georgalis et al. 2016a). Scale bars equal $1 \mathrm{~mm}$

of most of the remains, might have also contributed to the current absence of extinct species described from the Neogene and Quaternary of Europe.

The geographical and temporal distribution of agamids in Europe has been briefly summarized in a recent paper by Blain et al. (2016) as an update of Delfino et al. (2008). As

shown by the authors, a trend towards a southward shifting of their distribution probably linked with climate changes is evident from the Miocene onwards, starting from an Eocene distribution that reached Belgium in the North. During the Pliocene and even more during the Pleistocene, agamids appear to be confined in Mediterranean countries, 
such as Spain, Mediterranean France, Italy and Greece. The Italian post-Miocene record is particularly scarce, with a single occurrence in continental Italy (Early Pleistocene, MN 17, of Montagnola Senese; Delfino, pers. obs in Delfino et al. 2008; note that this locality is incorrectly included in the Pliocene range in Blain et al. 2016) and a rather high number of remains from Monte Tuttavista in Sardinia (Early to possibly Middle Pleistocene; Delfino et al. 2008; Fig. 5a-d). Agamids then disappeared from Western Europe by the end of the Early Pleistocene, with a single dentary from Sardinia possibly representing the only Middle Pleistocene evidence. However, Delfino et al. (2008) acknowledged that this isolated find could be an allochtonous intruder coming from older fissure fillings of Monte Tuttavista. In spite of a gap in the record between the end of the Pliocene and the present days, Greece is the only European country still hosting agamids (namely, Stellagama stellio) in its extant herpetofauna. The absence of significant fossils younger than Pliocene in age from the country, however, hinders the tracking of the origins of the extant Greek populations, even though it might also suggest a rather recent dispersal from the east or human-mediated introduction. Only future findings in the Greek part of the Aegean region dating back to the Quaternary could help to solve this issue.

A few remains previously assigned to agamids are now not considered to pertain to the family anymore. One fossil fragment coming from the Late Pleistocene of Tokod in Hungary (Meszoely and Gasparik 2002) was subsequently reassigned to a cyprinid fish by Gaudant (pers. comm. in Rage 2013). The same applies to another purported agamid bone fragment coming from the late Miocene of Ano Metochi 3 in Greece (Georgalis et al. 2017a). Młynarski (1956) tentatively identified a possible agamid fragment of mandible from Węże I (Pliocene of Poland), but later he retracted this identification (Młynarski 1962). Judging from the figure reported in his original paper (Młynarski 1956: Fig. 3), the specimen is indeed different from a standard agamid dentary in both tooth and overall morphology and can be, therefore, considered as an indeterminate squamate.

\section{Chamaeleonidae}

European fossil chamaeleons are rather important in the context of the poor fossil record of this family, since this area is one of the richest worldwide in term of remains attributable to these lizards (Böhme and Ilg 2003; Bolet and Evans 2013a; Georgalis et al. 2016a). Central Europe, in particular, has yielded an unexpectedly high number of Neogene chamaeleon fossils, if compared with the very scanty palaeontological record of the family in the rest of the world (even though this can be caused simply by a less extensive systematic research activity in Africa and Asia).
This scant nature of the record holds true for the rest of Europe also, where just very few occurrences are reported (one from Greece, one from Serbia and two from Spain).

All but one of the occurrences come from early-middle Miocene localities, spanning from MN 3 to MN 7. The single post-Miocene occurrence is represented by remains coming from the Holocene site of Cueva de la Victoria, near Málaga in southern Spain (Talavera and Sanchiz 1983), and attributed to the extant species Chamaeleo chamaeleon, still living in the area. Because of the scarce information given by the fossil record, it is not clear when and why the Neogene species disappeared from the continent and when the single autochthonous extant European species (namely, C. chamaeleon) spread into the country.

Six extinct European species have been described, all of them belonging to the genus Chamaeleo: Chamaeleo andrusovi Čerňanský 2010a, Chamaeleo bavaricus Schleich 1983, Chamaeleo caroliquarti Moody and Roček 1980, Chamaeleo pfeili Schleich 1984, Chamaeleo simplex Schleich 1994 and Chamaeleo sulcodentatus Schleich 1994. Čerňanský (2010a, 2011) considered both $C$. caroliquarti and $C$. pfeili as nomina dubia, because they are based only on fragmentary tooth-bearing bones lacking clear autapomorphic features allowing the identification of new species. A similar argument may hold true for C. simplex and C. sulcodentatus too, which in turn have been described based on fragmentary remains, but a revision of the type material is needed to clarify this.

Because of the poor fossil record of European chamaeleons on the whole, the known geographic range of most of the described extinct species is scarcely understood. Most species are known only from one or a few localities very close to each other. So far, $C$. simplex has been recorded only from the type locality, the German site of Randecker Maar, whereas the occurrences of C. bavaricus, C. pfeili and $C$. sulcodentatus are limited to southern Germany (with the single exception of an unpublished mention of the latter species from Switzerland; Böhme 2003; Böhme and Ilg 2003). Chamaeleo caroliquarti seems to have a wider record (based in part on unpublished and therefore possibly questionable occurrences), but still it is mainly centred in southern Germany. Nevertheless, the type locality of this species is in Czech Republic (Moody and Roček 1980). If confirmed, a possible occurrence of this species in the Burdigalian of southern Spain (Agramón, province of Albacete; Böhme and Ilg 2003) would be very interesting, but it must be taken with caution given that it is still unpublished. The distribution of $C$. andrusovi is rather interesting too, even though it is currently known from very few localities. This species was originally described from Dolnice, in Czech Republic (Čerňanský 2010a), but remains from two other localities have been attributed to Chamaeleo aff. C. andrusovi. Interestingly, these two 


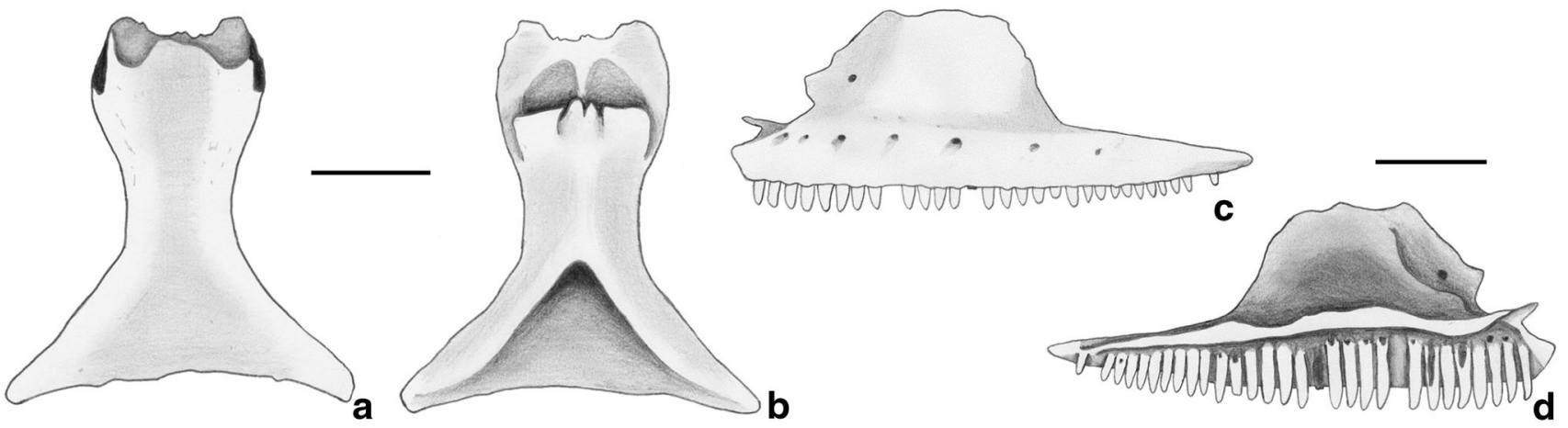

Fig. 6 Hemidactylus cf. H. turcicus from Valdemino Cave: frontal (VAL MF 14) in dorsal (a) and ventral (b) views; left maxilla (VAL MF 13) in lateral (c) and medial (d) views. Scale bars $=2 \mathrm{~mm}$

localities, Hambach 6C in northwestern Germany (̌̌erňanský et al. 2017b) and Aliveri in Greece (Georgalis et al. 2016a; Fig. 5g-h), are located at the opposite sides of Europe, greatly extending the known range of the species.

In terms of temporal distribution, C. caroliquarti is also the extinct species that spans the longest time interval (MN 3a to MN 6), overlapping the stratigraphical range of other species too. The range of the other species is obviously restricted by their fewer occurrences, with $C$. andrusovi reported from MN 4 to $\mathrm{MN} 5, C$. bavaricus from MN 5 to MN 6, C. pfeili only from MN 4b, C. simplex only from MN 5 and $C$. sulcodentatus from MN 5 to MN 6.

\section{Gekkota}

Fossil remains of gekkotans are known throughout the entire Neogene and Quaternary of Europe. Today, European representatives of these reptiles are confined to Mediterranean countries, with Mediodactylus kotschyi alone present also along the coasts of the Black Sea (Sillero et al. 2014). However, similar to other lizards groups, their geographic range was far more widespread during the Miocene, extending as far North as southern Germany and northwestern Czech Republic in the North at least. A restriction towards a circum-Mediterranean distribution appears to be recognisable already in the Pliocene and no occurrence is known outside this range subsequently. This is similar to the trend shown by agamid fossils on the continent (Blain et al. 2016; see above) and could likewise be due to a progressive cooling of the climate in Europe.

Traditionally, geckos were subdivided into two families, Gekkonidae and Pygopodidae (Evans 2008; Vitt and Caldwell 2009), but seven different families were defined in recent phylogenetic analyses (see, e.g., Gamble et al. 2012, 2015). In the same way as most of the agamid fossils were attributed to Agama (see above), most European remains of indeterminate geckos have been attributed to Gekkonidae (i.e., non-pygopodid gekkotans) in the past, as a result of the traditional classification. Most of these attributions would be more probably compatible with an identification as indeterminate gekkotans now, even though the possible presence of diagnostic features allowing their identification as members of other gekkotan families must not be discounted without a revision of each single occurrence. Nevertheless, remains of undisputed gekkonids are indeed present in Europe: they all pertain to the genus Hemidactylus and come from the Middle Pleistocene to Holocene of France (Middle Pleistocene/Holocene of Lazaret Cave; Bailon 1991) and Italy (Holocene of Grotta Curbeddu; Delfino 2006). A possible third occurrence of Hemidactylus might be represented by remains coming from the Middle Pleistocene of Valdemino Cave, in Italy (Fig. 6). These bones, including a frontal, a maxilla and two dentaries, were described by Delfino (2004) in his overview of the fossil herpetofauna from the cave. Based on size, morphology of the anterior premaxillary process, width and robustness of the palatal shelf and medial inclination of the facial process of the maxilla, he assigned the remains to Tarentola $\mathrm{cf}$. T. mauritanica. A revision of the material revealed that the maxilla bears a sigmoid ridge on the medial surface and the frontal has large lateral processes (A.V., pers. obs). According to a recently published comparative study of the cranial osteology of extant European gekkotans (Villa et al. 2018c), these are distinctive features of Hemidactylus turcicus among extant European species. In contrast, Tarentola mauritanica has a smooth maxillary medial surface and no lateral processes on the frontal. The size of the remains is also comparable with a large individual of $H$. turcicus. Yet, it has to be noted that $H$. turcicus displays a faint ornamentation on both the frontal and the maxilla (Villa et al. 2018c), whereas the specimens from Valdemino are smooth (A.V., pers. obs.). Because of this, these fossils are here referred to as Hemidactylus cf. H. turcicus, but it is not possible to completely exclude that they belong to another extant species of Hemidactylus currently not living in Europe or 
even to a still unrecognized extinct species of the genus. In this context, it is interesting to note that Bailon (1991) described a smooth lateral surface also for the maxillae from Lazaret Cave, which is located in southeastern France not so far from Valdemino Cave. However, the maxillae were not figured and they have never been properly published; so, it is not possible to check whether the ornamentation is indeed lacking or it just went unnoticed. If the absence of this feature in the French maxillae is confirmed, it would become clear that a peculiar population of Hemidactylus (or H. turcicus) was present along the coast of the Ligurian Sea during the Middle Pleistocene. Böhme and Ilg (2003) report another gekkonid, namely Gekko sp., from a few French sites dated back to the early Miocene (MN 2): Chavroches P1, Chavroches P1C2, Le Gondailly and Montaigu-le-Blin. However, Böhme (2003) mentions the same occurrences as pertaining only to indeterminate Gekkonidae. Given that no other fossil occurrence of this southeast Asian genus is currently known in Europe (except for another, unpublished mention from the Chattian of Gannat, still in France, included by Böhme and Ilg in their online database) or nearby countries, the identification of the French remains is rather dubious and they should likely be considered indeterminate gekkotans pending a thorough study.

Two other gekkotan families are recorded with fossil representatives in the Neogene and Quaternary of Europe: Phyllodactylidae and Sphaerodactylidae. This means that all three families that are currently present on the continent are also reported in the fossil record, even though only sphaerodactylids are undisputedly present before the late Pliocene (phylogenetic relationships of Paleogene species are still unclear; see Daza et al. 2014 and Bolet et al. 2015). The oldest European phyllodactylids are known from Spain, where Tarentola has been reported from the Gelasian of Almenara Casablanca 1 (Blain 2005, 2009) and T. mauritanica from the Calabrian of Cueva Victoria (Blain 2005, 2009, 2015) and Quibas (Montoya et al. 2001; Agustí et al. 2009), as well as from the Early Pleistocene (early Biharian) of Cementerio de Orce (Bailon 1991). An even older possible occurrence of a form morphologically similar to Tarentola might be represented by some few dentaries found in Cova Bonica (MN 16 of northeastern Spain), but this identification is mainly based on the size of the remains and should, therefore, been taken with caution (Blain 2009). Very few other localities from the Iberian Peninsula, France and Italy have yielded younger remains of Tarentola. Finding the oldest representatives of T. mauritanica (or closely morphologically related taxa) in Spain agrees with the hypothesis of an Iberian origin of the extant European populations of this gecko inferred from molecular analyses (Rato et al. 2010). However, given that fossil occurrences are also found in Pleistocene sites of other
European countries, fossil evidence is in contrast with the idea of a recent, rapid and maybe human mediated colonization, again suggested by molecular data (Harris et al. 2004; Rato et al. 2010). A similar colonization pattern was suggested for H. turcicus too (Carranza and Arnold 2006; Rato et al. 2011), but again the presence of European Pleistocene fossils might reject this hypothesis. Of course, a recent recolonization of areas previously occupied by older populations of $H$. turcicus and/or T. mauritanica might also be the case.

Sphaerodactylids are present in Europe since at least the early Miocene. Earliest representatives of this clade on the continent already include members of the extant genus Euleptes, among which the extinct species Euleptes gallica from the early Miocene of France (Müller 2001) and Czech Republic (Čerňanský and Bauer 2010), Euleptes klembarai from the middle Miocene of Slovakia (Estes 1969; Daza et al. 2014; Čerňanský et al. 2018), as well as indeterminate Euleptes from the early Miocene of Germany (Müller and Mödden 2001). A second genus, Gerandogekko, was also present during the Miocene in France, including two species that are known from the Aquitanian (Gerandogekko arambourgi, from Saint-Gérand-le-Puy; Hoffstetter 1946) and the late Miocene (Gerandogekko gaillardi, from La Grive-Saint-Alban; Hoffstetter 1946). However, arguments used by Hoffstetter (1946) and later Estes (1983) to separate the two species are considered rather weak by Daza et al. (2014), even though the latter authors do not directly suggest a synonymy due to the scarce material available. No other fossils clearly referred to sphaerodactylids are currently known since the Pliocene, even though gecko remains found in the Pleistocene of Monte Tuttavista in the Italian island of Sardinia, reported as Gekkonidae indet. by Abbazzi et al. (2004), seem to show close affinities with the extant Euleptes europaea (A.V., pers. obs.).

Another fossil taxon with uncertain phylogenetic relationships is reported from the Neogene of Europe: the German species Palaeogekko risgoviensis (middle Miocene; Schleich 1987; Böhme 2003). The systematic affinities of this species are rather dubious, but it is almost certainly not related to either eublepharids or pygopodoids (Schleich 1987; Daza et al. 2014). Given that the latter taxon include Pygopodidae, Carphodactylidae and Diplodactylidae, $P$. risgoviensis should belong to either one of the three gekkotan families already recognized in Europe or to another, still unrecognized family. It has to be noted that Daza et al. (2014) do not discount the possibility that the material assigned to $P$. risgoviensis belongs instead to more than one species. Gekkotan remains found in the Gargano "Terre Rosse" fissure fillings (late Miocene/early Pliocene of southern Italy; Delfino 2002, 2013) might also represent a new taxon with uncertain affinities (A.V., pers. obs. based on the material stored in the University of 

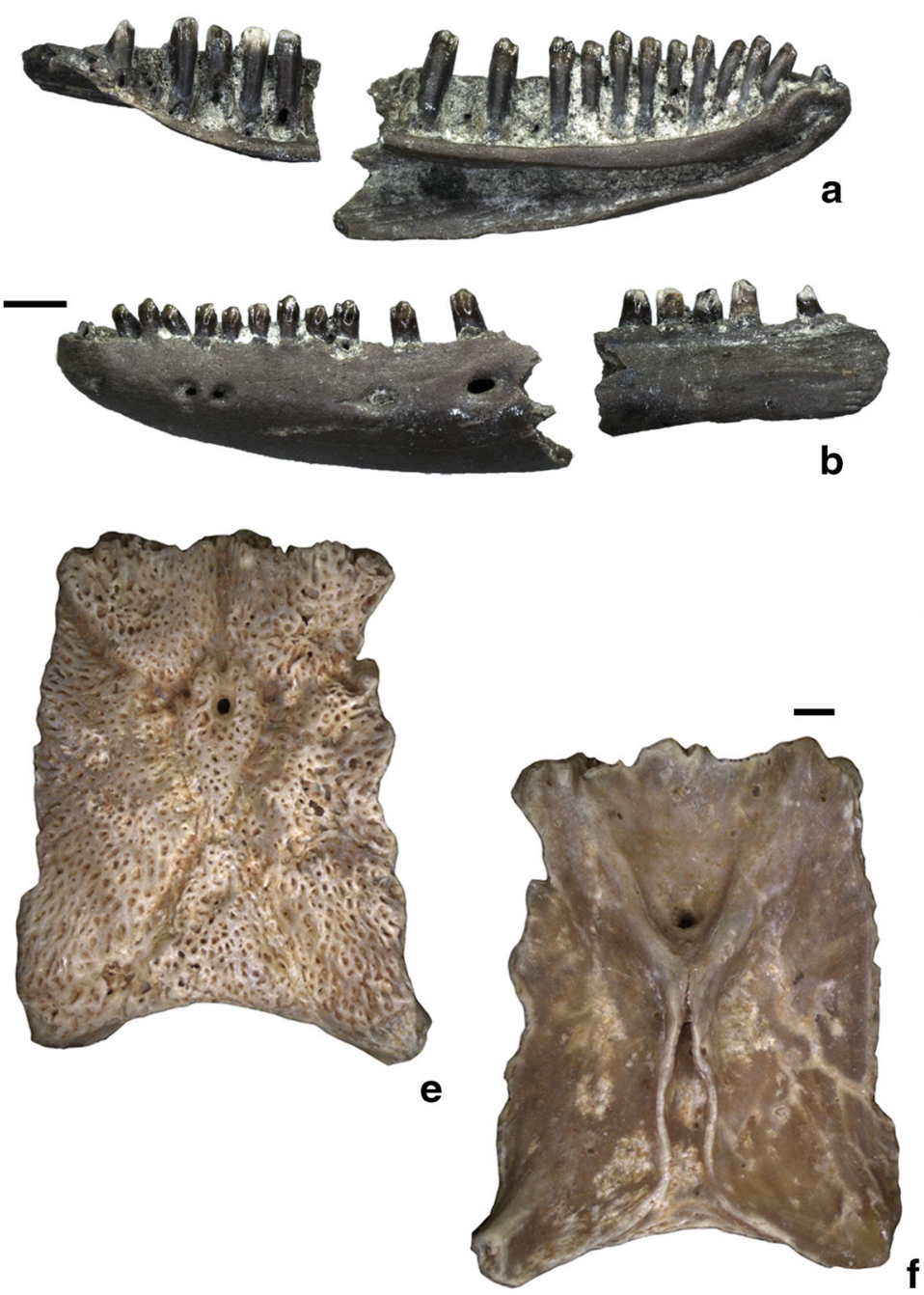
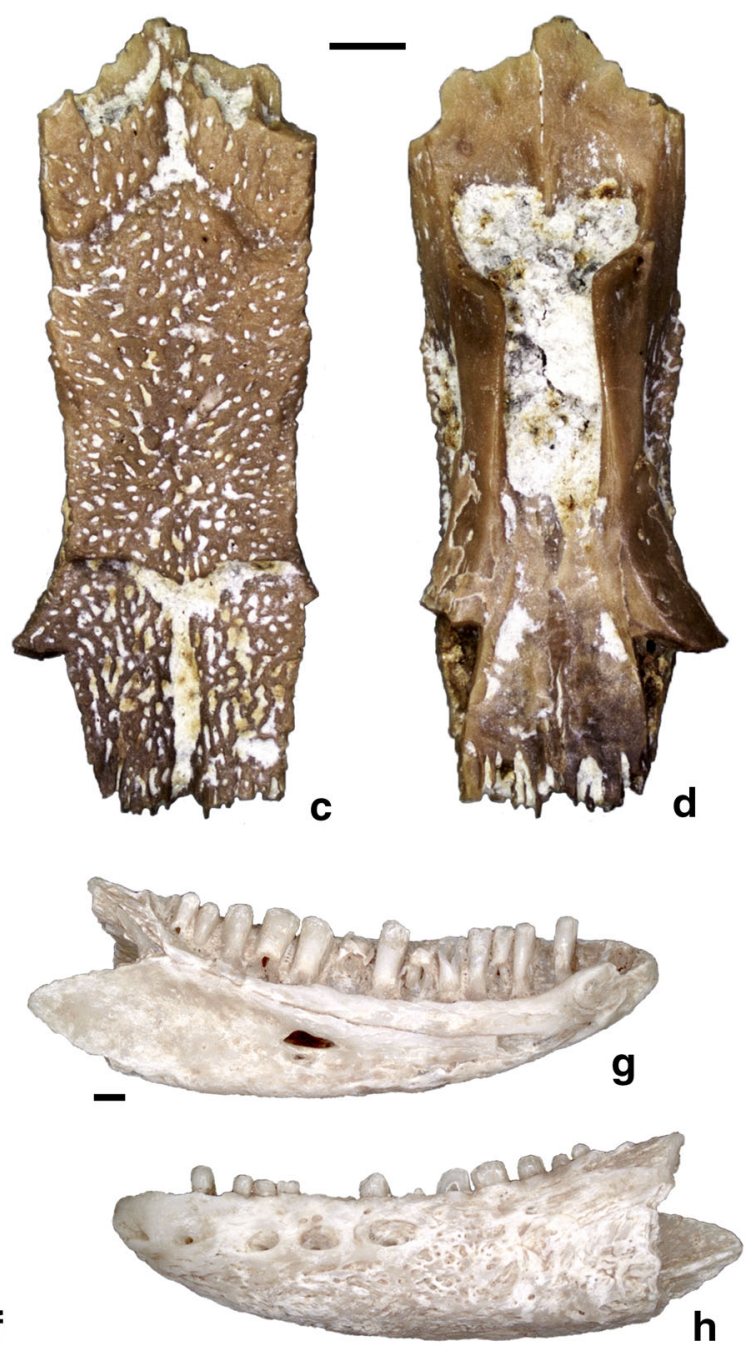

Fig. 7 Lacertid remains from Europe: left dentary (RGM 816720; ab) of Lacerta sp. from Tegelen, The Netherlands, in medial (a) and lateral (b) views (Villa et al. 2018b); fused frontals (MGPTPU 132532; c-d) of cf. Lacerta sp. from Moncucco Torinese, Italy, in dorsal (c) and ventral (d) views (Colombero et al. 2017); parietal

Florence). These remains are currently under study and a clear establishment of their identity and relationships is outside the scope of this overview.

In the end, Augé and Rage (2000) stated that Lacerta? ambigua, a species described by Lartet (1851) from Sansan, might be in fact a gecko. Unfortunately, the type material is now lost and there are no figures in Lartet's work. Because of that, this hypothesis cannot be either confirmed or rejected. Moreover, a fragment attributed to a possible gecko by Młynarski (1956) from the Pliocene of Węże I is not a gecko. Like the possible agamid he mentioned from the same site, he later corrected this identification, referring the fossil to an indeterminate squamate (Młynarski 1962).
(MT-IX-009; e-f) and left dentary articulated with the splenial (MTIX-056; $\mathbf{g - h}$ ) of Timon sp. from Monte Tuttavista, Italy, in dorsal (e), ventral (f), medial (g), and lateral (h) views (Tschopp et al. 2018). Scale bars equal $1 \mathrm{~mm}$

\section{Lacertidae}

During the Neogene and Quaternary, Lacertidae is by far the most represented lizard family in the European fossil record. Lacertids (Fig. 7) are reported almost continuously from the beginning of the Miocene up to the Holocene, and the geographic distribution of their fossil occurrences is also equally wide for this entire period of time. This might of course be a taphonomic artifact, but it could also represent a real dominance of this family on the continent since the Miocene at least, as it is the case in its modern lizard fauna.

Both extinct and extant taxa are known as fossils. Extinct ones are mainly confined to the Miocene, even though a few exceptions from the Pliocene and the Pleistocene do exist. It has to be noted, however, that a number 
of extinct species erected in the past are now considered either not valid or problematic. This is the case, for example, of most of the lacertid species named by Lartet (1851) from the middle Miocene of Sansan, in France. Of the five species he erected, only Lacerta sansaniensis (now Edlartetia sansaniensis; see below) is currently considered as a valid species, following the description of new material by Augé and Rage (2000). The descriptions of the other four species, Lacerta ponsortiana, Lacerta bifidentata, Lacerta philippiana and Lacerta? ambigua, given by Lartet (1851) in his work are very brief and, given that the remains are not figured and the original material is currently lost, inadequate for sustaining their validity. Because of this, all of them have been subsequently considered nomina dubia (Estes 1983; Augé and Rage 2000). Both Estes (1983) and Augé and Rage (2000) noted that at least some of these species might not even be attributable to lacertids, as e.g., Lacerta? ambigua, which might instead represent a gekkotan.

Two Pliocene species have also been questioned: Lacerta crassidens and Lacerta ruscinensis. The former was briefly described by Gervais (1859) based on few remains coming from Issoire (France), but Estes (1983) considered these remains too fragmentary and undiagnostic and the species as a nomen dubium. Remains of the latter, a dentary and a vertebra, found in the Pliocene sediments of the French locality of Roussillon and described as a new species by Depéret (1890), appear to be very similar in size and morphology to the ocellated lizard Timon lepidus, from which it differs based only on few (and probably devoid of real diagnostic significance) characters: that is, slightly more delicate tooth morphology and a lower number of mental foramina (see also Estes 1983). Based on the current knowledge, it seems not possible to clearly separate these remains from those belonging to extant large lacertid species and therefore, a possible attribution to one of the latter should not be excluded, as already suggested by Estes (1983). Also because of that, the occurrence of L. ruscinensis in Csarnóta 2 (early Pliocene of Hungary) mentioned (but neither described nor figured) by Jánossy (1986) appears doubtful.

Problematic taxa come from the Pleistocene of Austria, France, Italy and Malta. Rauscher (1992) described two new species from Bad Deutsch-Altenburg, in Austria: Lacerta altenburgensis and Podarcis praemuralis. Lacerta altenburgensis is based on a single specimen, a maxilla, which is considered aberrant by the author. However, this supposed aberrant morphology is due to the fragmentary nature of the specimen, and no significant diagnostic feature can be observed in its preserved portions (E. Tschopp, pers. com. 2017). Podarcis praemuralis, on the other hand, is based on more material. Nevertheless, the main features that are reported to differentiate this species from the very similar P. muralis (such as a wider and more rounded ascending nasal process of the premaxilla, a slightly less wavy crista dentalis of the maxilla and a less developed carina zygomatica) might alternatively fall into the normal individual variation of the latter and other extant Podarcis species. The type material of $P$. praemuralis seems, therefore, to be non-diagnostic at species level. Because of that, both these Austrian species are herein considered nomina dubia. Lacerta fossilis, reported by Pomel (1853) from Late Pleistocene localities in France and attributed to an indeterminate species of Lacerta by Böhme and Ilg (2003), is a nomen dubium, as already stated by Estes (1983) and Holman (1998). Indeed, the original description of the species is too vague to sustain its validity and no figure is given by the author. As is the case for other problematic lacertid species, the original material studied by Pomel is currently lost. Lacerta castellanensis, a possible endemic Sicilian species based on a single specimen found in Castellana (De Gregorio 1925), is most probably not a Lacerta according to Kotsakis (1977). This hypothesis has been generally followed by later authors (e.g., Estes 1983; Caloi et al. 1986; Holman 1998) and a revision of the type material would be needed to clarify the taxonomic assignment of this taxon. The problematic taxon from Malta is Lacerta melitensis, which is a nomen nudum (Böhme and Zammit-Maempel 1982; Bailon 2004). As a matter of fact, the first mention of the species is found in a review of the fossil animals from the island presented by Gulia at the IX International Congress of Zoology (Gulia 1914). In that circumstance, he listed the new specific name in brackets referring to a large-sized lizard he already mentioned one year before (Gulia 1912), but without giving neither any explanation for the mention of the new name nor any description or figure. Later, Savona Ventura (1984) stated that the remains assigned to L. melitensis by Gulia were in fact those of a lizard reported from Ta' Gandja and Benghisa Gap and attributed simply to Lacerta sp. by Adams (1866). This material is lost (Böhme and Zammit-Maempel 1982) and therefore, it is not possible to check whether the taxon referred to as L. melitensis could be considered a valid species or it must be considered conspecific with the other large lacertid known from the Pleistocene of Malta, "Lacerta" siculimelitensis (see below).

Among the valid species, particularly interesting are the amblyodont forms. Amblyodonty (sensu Hoffstetter 1944) was not uncommon among lacertids during the Paleogene (for a review of Paleogene amblyodont taxa, see Augé et al. 2003, 2005; Bailon et al. 2014; Čerňanský et al. 2017a) and the success of this peculiar feature seems to have lasted into the Neogene at least until the middle Miocene. The most widespread genus is the moderately amblyodont Amblyolacerta (type and only known species: 
Amblyolacerta dolnicensis Roček 1984), which is known from the early to middle Miocene spanning from Czech Republic (Roček 1984) to Germany (Böhme 1999a, 2003; Abdul Aziz et al. 2008) and France (Augé and Rage 2000; Augé 2005), and maybe also in Switzerland (Böhme 2003; Böhme and Ilg 2003). The degree of amblyodonty is higher in both Ligerosaurus pouiti and Janosikia ulmensis, two species currently found only in the middle Miocene of northwestern France (Augé 1993; Augé et al. 2003) and in the early Miocene of southern Germany (Čerňanský et al. 2016a), respectively. New occurrences of J. ulmensis from the middle Miocene of Germany have been recently mentioned by Villa and Delfino (2017), but these remains are still unpublished. Adding to these, Villa et al. (2018e) referred to Janosikia also the type material of the two species of the supposed cordylid Bavaricordylus (see below). Villa and Delfino (2017) also reported from southern Germany the youngest representative (early Miocene) of Mediolacerta, a genus with a moderate degree of amblyodonty previously found only in the Oligocene of both France (Augé 2005) and Germany (Čerňanský et al. 2016b). It appears, therefore, that amblyodont (either at a moderate or an higher degrees) lacertids and the feeding habits linked with their tooth morphology still had a role in Miocene ecosystems, at least previous to the late Miocene. Then, this morphology disappeared in European lacertids, remaining limited to another lizard group (namely, anguids of the genus Pseudopus, whose increasing distribution is considered a possible cause for the disappearance of amblyodont lacertids by Augé et al. 2003 and Klembara et al. 2017). Only a single lacertid species showed again an amblyodont dentition by the beginning of the Pliocene: Maioricalacerta rafelinensis. The range of this species is limited to the island of Mallorca, and its high degree of amblyodonty possibly evolved independently under the particular insular conditions from an ancestral form provided with a more generalized dentition (Bailon et al. 2014). However, Tschopp et al. (2018) recently recovered $M$. rafelinensis as sister to J. ulmensis. More data, including new material attributable to the Mallorcan species, are needed to better understand its relationships.

The European Miocene hosted other lacertid taxa with a peculiar, even though non-amblyodont, dentition, such as Edlartetia. The type species, Edlartetia sansaniensis, was originally described as Lacerta sansaniensis by Lartet (1851), but later moved to its own genus by Augé and Rage (2000) because of its unique dentition provided with a constriction below the crown, a feature never found in any other lacertid lizard neither fossil nor extant. The type locality of the species is Sansan (middle Miocene, MN 6, of France), but it was later reported from the Burdigalian (MN 5) and maybe Serravallian (MN 8) of Germany (Böhme 2010; Villa and Delfino 2017) and from the
Tortonian (MN 11) of Austria (Tempfer 2005) too. Other remains attributed, or tentatively attributed, to the genus are known also from other German and Austrian earlymiddle Miocene localities (Böhme and Ilg 2003; Böhme and Vasilyan 2014; Villa and Delfino 2017). A possible, though still unpublished, occurrence is also mentioned by Böhme and Ilg (2003) from the middle Miocene of Toril 2, in Spain. The dentition of Miolacerta, a genus known from a number of localities in Central and Eastern Europe spanning from the early to the late Miocene, was also considered distinctive in having a strongly tricuspid crown in the posterior teeth (Roček 1984). Given that a similarly high degree of tricuspidity is not unknown among other lacertids (being present in Takydromus and Gallotia among extant genera, for example; see Kosma 2004), it is not unlikely that at least some fragmentary remains previously tentatively identified as pertaining to Miolacerta (e.g., fossils from Sandelzhausen; Böhme 2010) could belong to other lacertids instead. Nevertheless, rather confident occurrences of Miolacerta tenuis, the only species currently included in the genus, are reported from Czech Republic (early Miocene of Dolnice; Roček 1984) and Austria (latest middle Miocene of Gratkorn and late Miocene of Kohfidisch; Tempfer 2005; Böhme and Vasilyan 2014).

Another extinct Miocene species, Lacerta poncenatensis, is known from few early Miocene localities. This species was firstly described from Poncenat, in France, by Müller (1996). It was later recovered in Germany at Wiesbaden-Amöneburg (Čerňanský et al. 2015) and possibly in Austria at Oberdorf (Čerňanský 2016). In spite of the few known occurrences, therefore, L. poncenatensis could have had a moderately wide distribution during the early Miocene. Čerňanský et al. (2015) observed that certain features present in the specimens they assigned to this species, such as the presence of slightly tricuspid teeth, reduced the differences between $L$. poncenatensis and another species reported from Poncenat: namely, Lacerta filholi. Nevertheless, they still considered the two species as distinct, given the maintenance of other differences, even though hinting at a possible future synonymy due to the desirable finding of new specimens. In any case, the record of L. filholi at Poncenat (Augé and Smith 2009) is one of its latest occurrences, together with Montaigu-leBlin (Augé et al. 2003). This species is largely known from the Oligocene of France and Belgium (Böhme and Ilg 2003), but then it apparently had a drop by the Oligocene/ Miocene boundary, a period that has already been considered critical for squamate reptiles (see Rage and Szyndlar 2005, 2013). The two French occurrences are the only mentions of the species in the Neogene, likely indicating that it quickly went extinct after the boundary for some reason. 
The youngest extinct species known from Europe is "Lacerta" siculimelitensis, a large-sized lacertid described from the Late Pleistocene of Malta by Böhme and ZammitMaempel (1982) and associated by the same authors with other fossils coming from the Middle Pleistocene of Sicily previously mentioned as a large Lacerta species by Kotsakis (1977). Other Middle/Late Pleistocene Sicilian remains were subsequently attributed to the species by following authors (Caloi et al. 1986; Bonfiglio and Insacco 1992; Bonfiglio et al. 2002) and Delfino and Bailon (2000) recognized a shared dental morphology also in remains attributed to Lacerta from the Early Pleistocene of Pirro Nord in Apulia. The validity of "Lacerta" siculimelitensis, however, was questioned by authors such as Mateo (1988) and Barahona and Barbadillo (1997), based on the fact that the main diagnostic features seem to fall into the range of variation of other lacertids such as T. lepidus. The taxonomic status of this species is, therefore, in need of a revision, which is currently underway.

The presence in Europe of taxa that were closely related to extant species is attested since the beginning of the Neogene, with the oldest representatives of lacertids of the green lizards group reported from the early Miocene (MN 4b) of Dolnice in Czech Republic (Čerňanský 2010b; Rage 2013). Except for two other occurrences of the same species complex in the late Miocene (Kohfidisch in Austria and Polgárdi 4 in Hungary; Tempfer 2005; Venczel 2006), all other reports of extant species or related forms are younger than the Miocene/Pliocene boundary. This could mean that, even though some taxa might have started to evolve earlier, the settling of most of the modern lizard fauna of the continent has to be traced back to the second part of the Neogene. It has to be taken into account, however, that a lot of remains attributed only to indeterminate lacertids (sometimes assigned to the former wastebasket taxon Lacerta sp. in a broad sense) were indeed found in a very high number of Neogene localities and some modern taxa might have passed unnoticed in older sites given the overall difficulty in identify isolated lacertid bones (Villa et al. 2017a). Adding to this, it should be also noticed that some occurrences of extant taxa in Quaternary and even late Neogene sites might have been based mainly on biogeography, thus leading to questionable identifications. An example of such issue could be the identification of Lacerta agilis and Zootoca vivipara in Steinheim an der Murr (Late Pleistocene of Germany; Bloos et al. 1991). A quick review of this material, stored in the collections of the Staatliches Museum für Naturkunde Stuttgart, revealed that it might be more confident to assign most of the remains to indeterminate lacertids, even though at least two different species might indeed be present (A.V., pers. obs.).
After having specified that, the current fossil record of extant lacertids indicates that green lizards are widely reported throughout Europe from the Zanclean onwards (adding to the three Miocene occurrences, of course). A similar stratigraphic distribution is observable for Podarcis, even though most of the specific identifications might be based mainly on biogeography (e.g., occurrences of Podarcis lilfordi in the Balearic Islands, Podarcis pityusensis in Ibiza and Podarcis tiliguerta in Corsica). Acanthodactylus erythrurus (or related forms) is known in the Iberian Peninsula since the Early Pleistocene, but Böhme and Ilg (2003) reported a single dentary of Acanthodactylus sp. from the Zanclean of La Gloria 4. This latter occurrence, still unpublished, needs to be confirmed. Psammodromus has a similar Early Pleistocene-Holocene Iberian record, with most of the occurrences pertaining to Psammodromus algirus and a single mention of cf. Psammodromus hispanicus from the Middle Pleistocene of Áridos-1 (Blain et al. 2014b, 2015). Early PleistoceneHolocene records are known also for $T$. lepidus and $Z$. vivipara, even if their geographical range is broader than that of the previously mentioned Iberian species (in particular as far as $Z$. vivipara is concerned). Remains of Archaeolacerta bedriagae are mentioned from a number of Middle Pleistocene-Holocene localities in Corsica (Ferrandini et al. 1995; Salotti et al. 1997, 2008; Vigne et al. 1997, 2002; Bailon 2004) and from a single late Pliocene/ Early Pleistocene site in Sardinia (Bailon 2004; Delfino 2006). The single fossil occurrences of Dalmatolacerta oxycephala and Ophisops elegans are represented by isolated dentaries coming from the Plio-Pleistocene site of Bad Deutsch-Altenburg (Rauscher 1992). However, the taxonomic significance of dentaries of extant European lacertids is not really clear, due to high individual variation (A.V., pers. obs.), and so these occurrences should be treated with caution. Eremias sp. is mentioned from Ozyornoye-1 in Ukraine (Middle Pleistocene/Holocene; Böhme and Ilg 2003).

In the end, it is worth mentioning the still unpublished report of indeterminate Eremiadini in the karstic network of Cava Monticino, in Italy (Villa et al. 2016). This late Miocene (MN 13) occurrence is the only known mention of this lacertid tribe in Italy, both if considering the fossil record and the extant herpetofauna.

\section{Scincidae}

Considering only the Neogene and Quaternary, skinks (Fig. 8a-d) are reported in Europe from the beginning of the Miocene up to the Holocene, even if they are not as common in the fossil record as other groups such as lacertids or anguids. Similarly to other families, their geographic range was wider during the Miocene, compared to 

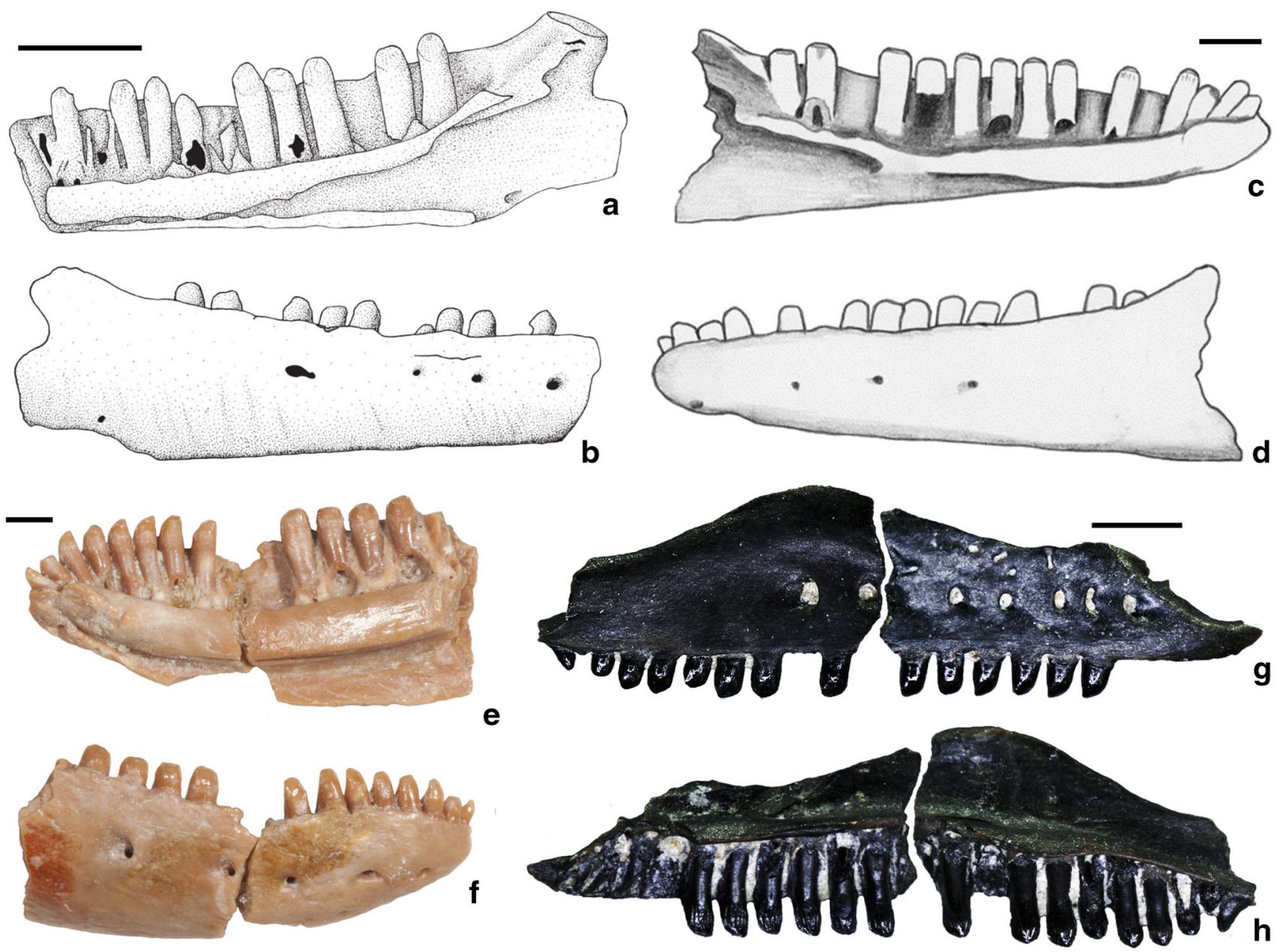

Fig. 8 Scincid and cordylid remains from Europe: right dentary (a, b) of Chalcides cf. C. bedriagai from Almenara-Casablanca-3, Spain, in medial (a) and lateral (b) views (Blain et al. 2007); left dentary (c, d) of Chalcides ocellatus from Porto Leccio, Italy, in medial (c) and lateral (d) views (Delfino 2002); right dentary (BSPG 2008 XXIV 1;

following epochs. From the Pliocene onwards, they are found only in Mediterranean countries, with the sole possible exception of a single (unpublished) occurrence in Bulgaria during the Gelasian (Varshets; Böhme and Ilg 2003). However, even if this is rather consistent with their current distribution in Europe, it is possible that the missing recognition of a wider distribution, especially in the Pliocene, is an artifact of low sample size.

Two extinct species are known, both from the Miocene of southern Germany. Bavariascincus mabuyaformis was tentatively attributed to Scincidae by its author, Kosma (2004). The type material comes from Petersbuch 2 and Rembach, both MN 4 in age. However, the original description of the species is reported in Kosma's $\mathrm{PhD}$ thesis and it has never been published elsewhere. Because of this, both the genus Bavariascincus and the species B. mabuyaformis should be considered nomina nuda (see Villa et al. 2018e, for a complete discussion on why taxa

e,f) of Bavaricordylus molassicus from Puttenhausen 2, Germany in medial (e) and lateral (f) views (Böhme 2010); right maxilla (UU AM3 506; $\mathbf{g}, \mathbf{h}$ ) of ?Cordylidae indet. from Ano Metochi, Greece, in lateral (g) and medial (h) views (Georgalis et al. 2017a). Scale bars equal $1 \mathrm{~mm}$

erected in Kosma's thesis cannot be considered valid). In any case, the dentition of the material from both Petersbuch and Rembach indeed recalls scincid tooth morphology. A revision is needed to test the taxonomic assignment. A third occurrence of B. mabuyaformis is reported by Böhme and Ilg (2003) from Forsthart, still MN 4 of southern Germany, but it has never been published or figured. At the moment, it should be considered dubious, given also the problems linked with the availability of the species. The second species, Tropidophorus bavaricus, was described by Böhme (2010) based on material coming from the MN 5 of Sandelzhausen, with additional material reported from the coeval locality of Oggenhausen 2 (Böhme and Ilg 2003). This species is rather interesting because it is the only known fossil record of Tropidophorus, a genus currently living in southeastern Asia. Moreover, the presence in the early Miocene of Europe of a skink with Asian affinities might agree with the supposed Asian origins 
reported for other European Miocene lizards, such as varanids (Conrad et al. 2012; Georgalis et al. 2017b).

Among extant taxa, Chalcides is the most frequently reported genus in the European skink fossil record. It is already reported from the middle/late Miocene of the Felsötárkány Basin in Hungary, where a species close to Chalcides ocellatus could have been present (Venczel and Hír 2013). The oldest specific mentions of extant species date back to the Early Pleistocene (Chalcides bedriagai; Blain et al. 2008; Blain 2015), Middle Pleistocene (Chalcides chalcides and Chalcides striatus; Delfino 2002, 2013; Blain et al. 2012) and Late Pleistocene (Chalcides ocellatus; Delfino 2002; Delfino and Rook 2008; Fig. 8c-d). Nevertheless, it must be taken into account that, at least in some cases, these mentions could be based mainly on a biogeographical criterion.

Very few fossil occurrences are known for other extant European taxa: Ablepharus kitaibelii is reported in Greece from Vraona Cave, Pleistocene/Holocene in age (Rauscher 1995) and Heremites cf. H. auratus is mentioned (as Trachylepis cf. T. aurata) by Böhme and Ilg (2003) from Varshets, in the Gelasian of Bulgaria. Both these records are remarkable in being the only known fossil occurrences of their own taxa. Fossils from a number of localities spanning from the early Miocene-the Early Pleistocene were assigned, or tentatively assigned, to the genus Mabuya. Currently, species of Mabuya s.s. live in the Neotropics (Karin et al. 2016), but a number of other genera were also included in it in the past. The Eurasiatic Heremites auratus (Trachylepis aurata according to the old taxonomy still used, for example, in the most recent field guide of European amphibians and reptiles by Speybroeck et al. 2016) is one of the species previously included in Mabuya. It is, therefore, likely that European fossil records of Mabuya sp., cf. Mabuya sp. and aff. Mabuya sp. might be better identifiable as pertaining to Mabuya s.l. or Mabuyinae indet. Affinities with either Trachylepis/Heremites or one of the other African/Asiatic genera defined by Karin et al. (2016) are not possible without a thorough revision of all the material.

Southern Germany yielded other findings of possible skinks with extra-European affinities: namely, possible remains of Eumeces coming from few early-middle Miocene sites (Böhme and Ilg 2003; Villa and Delfino 2017). Even though these remains are still unpublished, the direct analysis of at least some of them supports their possible attribution to this scincid genus. Eumeces has a very complicated nomenclatural history, but it is currently restricted to species found in North Africa and Asia (Schmitz et al. 2004; Uetz et al. 2018). If the identification is confirmed by further studies, these would be the first mentions of the genus in Europe. Nevertheless, Eumeces was not apparently a long-lasting inhabitant of the continent.

\section{Cordylidae}

A certain degree of scepticism related to the accuracy of the attribution of European Neogene remains to Cordylidae might be raised by the complete absence of osteoderms clearly referable to this clade in European Neogene sites. Armored lizards like cordylids, gerrhosaurids and anguids are covered by a very large number of osteoderms, which outnumber bones of other skeletal districts like cranial elements. Preservation as fossils of these osteoderms is not uncommon and it would be expected that the probability of finding them in fossiliferous localities, where remains of armored lizards are reported, roughly follows this abundance. This is the case, for example, with anguids: when anguids are present in a fossil assemblage, osteoderms are often more abundant than other remains (cranial elements in particular). An exception to this pattern is represented by scincids, the osteoderms of which are composed by several ossification centres and are unlikely preserved (see, e.g., discussion related to the absence of free osteoderms in Scincoideus grassator in Smith and Gauthier 2013). The attribution to cordylids of a number of jaw elements from various European Neogene localities with no reports of associated osteoderms is, therefore, puzzling. Of course, there could be alternative explanations for this, such as: (1) the presence of some taphonomic bias affecting the preservation of osteoderms of European cordylids; (2) the belonging of European taxa to very basal stem representatives of the clade (devoid of osteoderms); or (3) a secondary loss of the osteoderms cover in the European Neogene cordylid lineage. Nonetheless, more data are needed in order to solve this taxonomic issue and European remains referred to cordylids are here reported as such, when there is no clear evidence against this attribution.

Few fossil occurrences of cordylids (Fig. 8e-h) are known in the Miocene of Europe and there is no record of this lizard family from the Pliocene onwards. The earliest Neogene European cordylids date to the early Miocene (MN 3), whereas the youngest ones come from late Messinian deposits (MN 13, probably also MN 13/14). Therefore, a survival of the family on the continent throughout the entire Miocene is likely, even though a shifting of their geographic range towards southeastern Europe (maybe also southwestern Europe, if the identification of a possible indeterminate cordylid from the Tortonian of Los Aguanaces, in Spain, is confirmed; Böhme and Ilg 2003) seems evident. Nevertheless, as far as our current knowledge can tell, they went locally extinct by the Miocene/Pliocene boundary. 
Adding to a limited number of still indeterminate forms, two different cordylid genera were reported from the Miocene of Europe. The first one, Bavaricordylus, is known only in the Burdigalian of southern Germany (Kosma 2004; Böhme 2010), with two different species, and in the early middle Miocene of Switzerland (Jost et al. 2015), with remains unassigned to species. The type species of the genus, Bavaricordylus ornatus from Petersbuch 2, was described by Kosma (2004) in his PhD thesis. Similarly to his Bavariascincus mabuyaformis (see above), this description should not be considered valid according to the rules of the International Code of Zoological Nomenclature, given also the absence of a successive paper sustaining it, and both Bavaricordylus and B. ornatus should be considered nomina nuda and so unavailable (see Villa et al. 2018e). This put an issue on the generic attribution of the second species, Bavaricordylus molassicus from Puttenhausen 2 and Sandelzhausen (Böhme 2010; Fig. 8e-f) and of the Swiss remains, too. A revision of the type material of both species of Bavaricordylus to assess their taxonomic identity supports the attribution of these remains to another lizard family then Cordylidae (Villa et al. 2018e): based on this new study, they should be referred to the lacertid genus Janosikia.

The second cordylid genus is Palaeocordylus, including a single species, Palaeocordylus bohemicus, originally described by Roček (1984) from the MN 4 of Dolnice in Czech Republic and later tentatively reported also from the slightly younger Czech locality of Merkur North by Čerňanský (2012). Remains attributed to this genus are reported also from Lautern 2 in Germany (Aquitanian, though still unpublished; Böhme and Ilg 2003). Böhme and Ilg (2003) mentioned a second species of Palaeocordylus, Palaeocordylus ulmensis, from a few southern German localities dated back to the late Oligocene and early Miocene. This is clearly a reallocation to this cordylid genus of Ophisaurus ulmensis Gerhardt, 1903 (as stated in Böhme and Ilg's database), but no explanation supporting it is given. Recently, remains of $O$. ulmensis coming from its type locality Ulm Westtangente have been recognized as pertaining to a lacertid lizard for which a new genus, Janosikia, has been erected (Čerňanský et al. 2016a). Other remains attributed to $P$. ulmensis by Böhme and Ilg come from localities that are very close to Ulm Westtangente both in geographical and stratigraphical terms and it is, therefore, possible that they also belong to Janosikia. However, a direct check of the fossils is necessary to confirm this.

\section{Anguidae}

After lacertids, anguids (Fig. 9) are the second most frequently reported lizard group in the Neogene and
Quaternary fossil record of Europe. They are widely recorded from the beginning of the Neogene onwards, with a species diversity that is rather high during the Miocene and later decreases from the Pliocene to the Holocene. Their geographic range has always been wide as a family, but in recent times, most of their occurrences outside Southern European countries are represented almost solely by the genus Anguis.

Known fossil remains of the latter genus are mostly assigned to the extant Anguis fragilis (or better to say, to the Anguis fragilis species complex because of the recent split of this species; Gvoždík et al. 2010, 2013), which is recorded in Europe since at least the late Miocene (e.g., a tentative record from the Felsötárkány Basin; Venczel and Hír 2013). In any case, pre-Pleistocene occurrences of A. fragilis are scarce. Two, or maybe more, extinct species are also known, even if their fossil record is very poor. Anguis rarus has been recently described based on a single parietal coming from the early Miocene (MN 3) of Petersbuch 62, in southern Germany (Klembara and Rummel 2018). Anguis stammeri also comes from Germany, namely from Fuchsloch (Brunner 1954), but it is distinctly younger than A. rarus, being Late Pleistocene in age. Both Estes (1983) and Klembara and Rummel (2018) considered A. stammeri as a possible valid species, although suggesting a revision, but it has to be noted that Młynarski (1962) pointed out Ophisaurus affinities for the type material. Due to some apparent morphological similarities, it is also possible that specimens attributed to A. fragilis or closely related forms, such as Anguis cf. A. fragilis reported by Młynarski (1962), might instead belong to this species (Estes 1983; Klembara and Rummel 2018). A possible third extinct species of Anguis is ?Anguis polgardiensis, originally described by Bolkay (1913) from Polgárdi 2 (MN 13 of Hungary) and later reported also from the older (MN 10) locality of Vösendorf, in Austria, by Papp et al. (1954). According to Estes (1983), this species is a junior synonym of Pseudopus pannonicus, but more recently Klembara (2015) and Klembara and Rummel (2018) stated that it is not possible to clearly allocate this material at generic level (mostly because the type parietal is lost and Bolkay did not provide figures of its ventral surface). Nevertheless, Klembara (2015) noted similarities between the dorsal ornamented surface of the parietals of ?Anguis polgardiensis and Ophisaurus spinari. Anguis? acutidentatus and Anguis? bibronianus were erected by Lartet (1851), but like most of the species named by this author from Sansan, their description is too vague to support their validity and there are no figures of them. Młynarski (1962) consider them as synonyms of Pseudopus moguntinus (that is, Pseudopus laurillardi in a modern view; see below), but since the type material is lost in both cases, it is better to considered them as nomina 

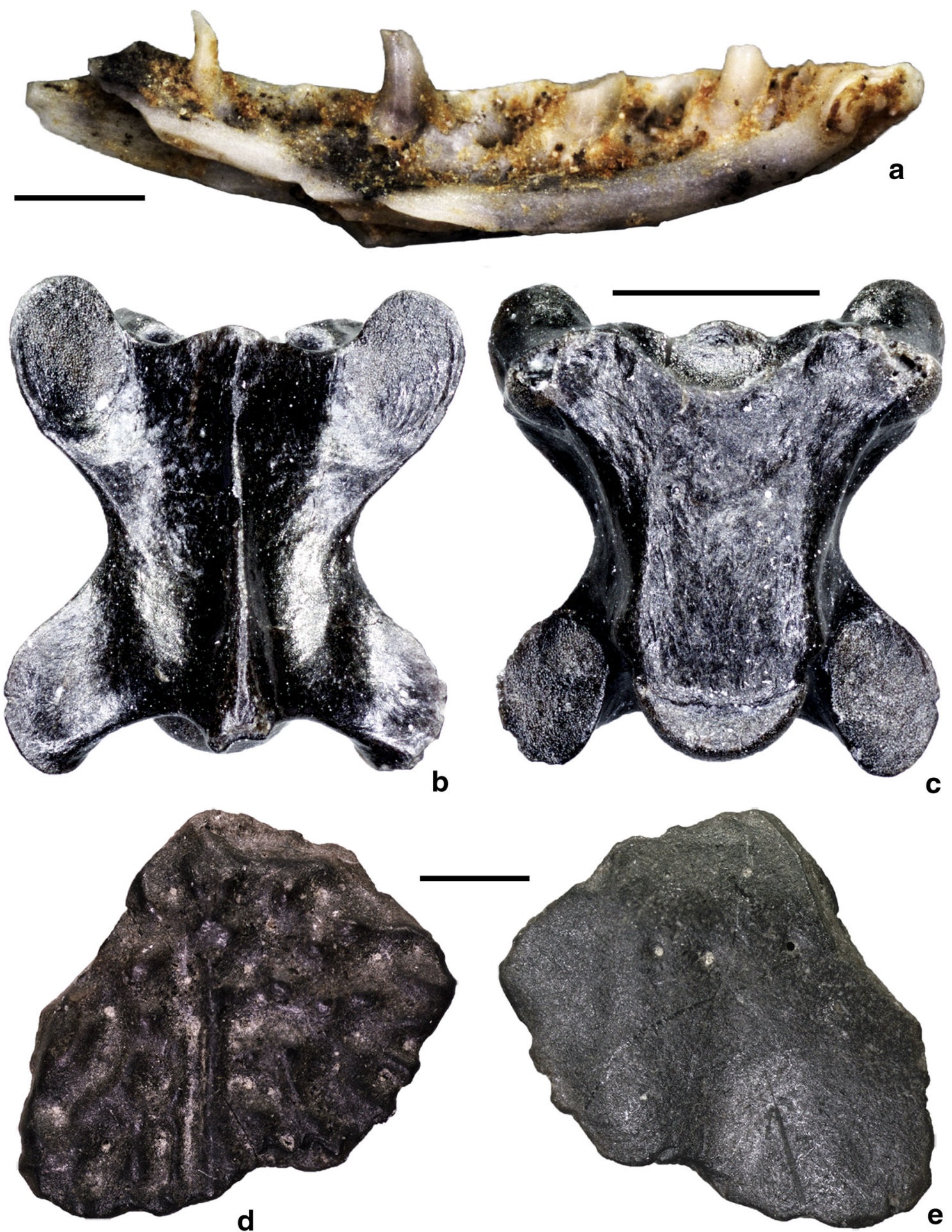

Fig. 9 Anguid remains from Europe: left dentary (RV-H-034; a) of Anguis gr. A. fragilis from Rivoli Veronese, Italy, in medial view (Villa et al. 2018a); trunk vertebra (IGF102243; b, c) of Anguis sp. from Fosso della Fittaia, Italy, in ventral (b) and dorsal (c) views

dubia following Estes (1983) and Augé and Rage (2000). In any case, the presence in Europe of unidentified species of Anguis is known since the very beginning of the

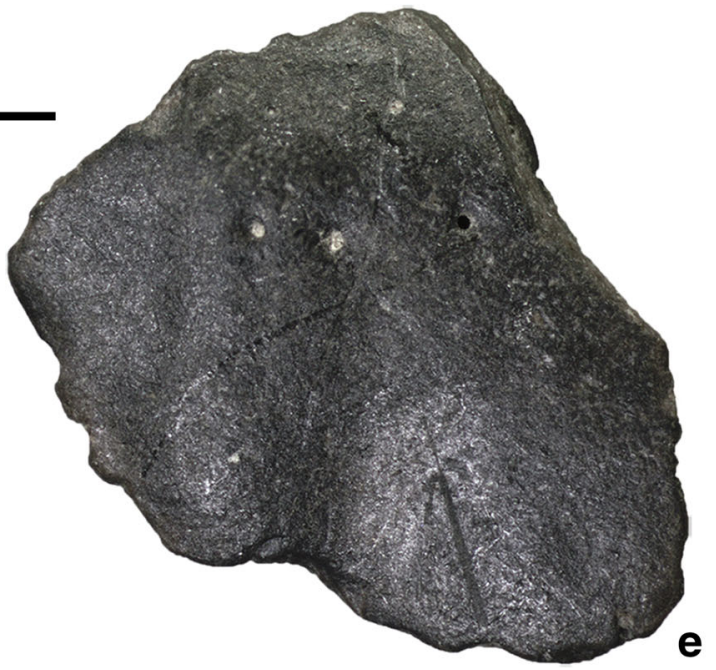

(Cirilli et al. 2016); osteoderm (RGM 816716; d, e) of cf. Pseudopus sp. from Tegelen, The Netherlands, in external (d) and internal (e) views (Villa et al. 2018b). Scale bars equal $1 \mathrm{~mm}$

Miocene and older remains are also known in the Paleogene (see e.g., Augé 2005). 
Pseudopus, the other anguid genus that still has extant representatives in Europe, is also present on the continent since the early Miocene, with few possible occurrences in the Oligocene too (Böhme and Ilg 2003; Čerňanský et al. 2016b). The oldest known species of the genus are Pseudopus ahnikoviensis and Pseudopus confertus. The latter (originally named Pseudopus rugosus, but later changed to $P$. confertus due to a possible risk of synonymy; Klembara 2015; Klembara and Rummel 2018) is known only from its type locality, Merkur North in Czech Republic (MN 3). Pseudopus ahnikoviensis, on the other hand, has a slightly longer stratigraphical distribution, spanning from the MN 3 to the MN 4 (maybe even MN 2 to MN 5). It has been found in Czech Republic and maybe Germany (Pseudopus cf. $P$. ahnikoviensis from Wiesbaden-Amöneburg and Hambach 6C; Čerňanský et al. 2015, 2017b). At least by the beginning of the MN 4, another species appears in the fossil record: Pseudopus laurillardi. Originally described by Lartet (1851) as Anguis? laurillardi from Sansan, it includes also Pseudopus fraasi (alternatively assigned also to Ophisaurus or to Propseudopus) and Pseudopus moguntinus (sometimes attributed to Ophisaurus) according to Klembara et al. (2010). It has to be noted that the type material of $P$. moguntinus was reported from the late Oligocene of Germany (Boettger 1875; Estes 1983; Klembara et al. 2010), thus leading to the supposed presence of an older occurrence of $P$. laurillardi. Nevertheless, Klembara et al. (2010) stated that P. moguntinus, as originally defined, should be considered a numen nudum, due to the fact that it is based on an unspecified number of poorly described and unfigured osteoderms, which are currently lost. Moreover, they added that the localities from which Boettger $(1875,1876 / 1877)$ reported his species are now considered to be dated between the middle Oligocene and the early Miocene. Because of all of this, they considered a Paleogene occurrence of $P$. moguntinus (and therefore of $P$. laurillardi) doubtful. Based on the current knowledge, the stratigraphical distribution of $P$. laurillardi spans from the MN 4 to the MN 9 and its geographical range includes Central and Western Europe. By the MN 9, $P$. laurillardi seems to be replaced by Pseudopus pannonicus, a species that is almost constantly found up to the Middle Pleistocene. Pseudopus pannonicus has a rather wide and stable distribution for most of its evolutionary history, being recorded from Western, Central and Eastern Europe in the Miocene, Pliocene and Early Pleistocene. Nevertheless, its youngest and only Middle Pleistoceneaged occurrence, Cengelle (the age of Canal Negre 1 in Spain is uncertain and could be older; Blain et al. 2016), is located in northeastern Italy (Delfino 2002). This might suggest a shrinking towards the southern margin of the continent during the Quaternary (Fig. 10), as is the case for other lizards, but this is only a conjecture due to the poor
Middle Pleistocene record. As for $P$. laurillardi, other species have been synonymized with $P$. pannonicus. Part of the type material of Varanus deserticolus Bolkay, 1913 from Beremend 1 in Hungary is actually referable to a large anguid, probably P. pannonicus (Estes 1983; Georgalis et al. 2017b). Pseudopus novorossicus, from the late Miocene of Ukraine (locality of Zhoften, also known as Petroviérovak; Alexejew 1912), is also considered a synonym of P. pannonicus (Estes 1983), as well as Ophisaurus intermedius, erected by Bolkay (1913) from Pliocene/ Pleistocene Hungarian localities and later mentioned by Jánossy (1986) also. The few fossil remains of the extant Pseudopus apodus are known since the late Pliocene. They are confined to Eastern Europe, suggesting that this species might never have expanded towards the Western part of the continent. Nevertheless, remains found in Hungary, Poland and Slovakia (Jánossy 1986; Klembara 1986; Holman 1998; Böhme and Ilg 2003) hint at a distinctly larger range of the species during the late Pliocene and the Pleistocene (see extant range in Fig. 10).

The genus Ophisaurus (as circumscribed by Klembara et al. 2014, that is including the American Ophisaurus, the Asiatic Dopasia and the African Hyalosaurus), which is currently absent from Europe, was also present on the continent during the Neogene and the Early Pleistocene. The few Middle and Late Pleistocene occurrences of the genus are questionable, as all records (without thorough descriptions and figures) date back to a period in which Pseudopus was also included in Ophisaurus and therefore they might represent occurrences of the former genus instead. The same taxonomic issue might also hold true for other indeterminate Ophisaurus occurrences from the continent. In any case, clear European Ophisaurus remains have been found from the Aquitanian (Ophisaurus cf. O. fejfari, MN 1/MN 2 of Oschiri in Sardinia, Italy; Venczel and Sanchiz 2006) to the late Early Pleistocene (Ophisaurus sp., Barranco Léon and Fuente Nueva 3 in southern Spain; Blain and Bailon 2010). Once again, the distribution of this genus shows a southward shrinking, starting from a wide range during the Miocene and narrowing towards Southern European countries in the Pliocene and the Early Pleistocene. In terms of taxonomic diversity, all Pleistocene occurrences and almost all the Pliocene ones are identified only at the genus level, but during the Miocene five different species are known. Most of these species but Ophisaurus acuminatus are based on parietals. Nevertheless, $O$. acuminatus, which is represented only by a partial skull found in Tortonian sediments of Höwenegg in Germany (Jörg 1965), indeed displays some differences from other Miocene Ophisaurus species, such as in the morphology of the dermal ornamentation of skull roofing bones (Klembara and Rummel 2018), and can be, therefore, maintained as a distinct species. Ophisaurus 

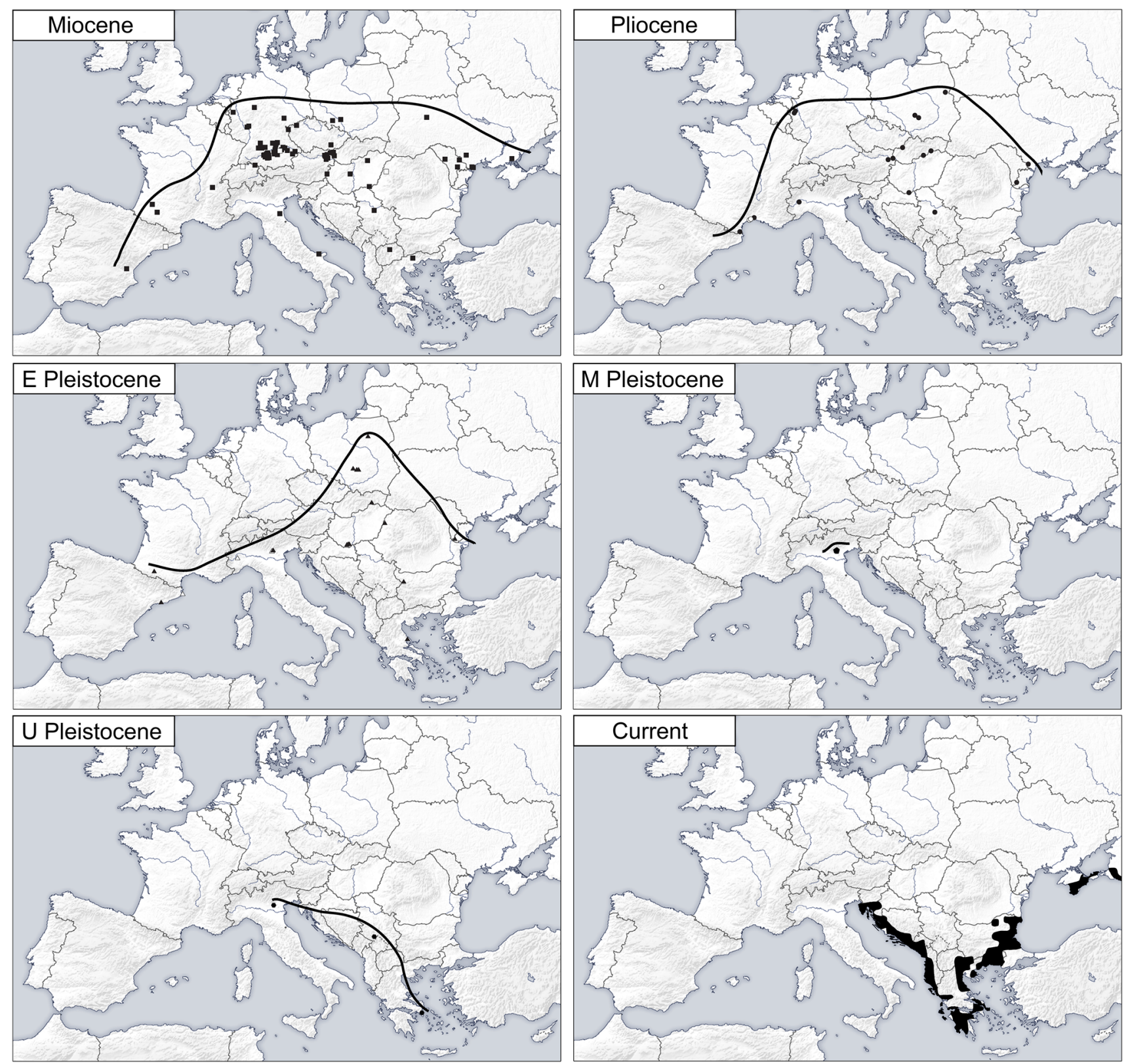

Fig. 10 Neogene and Quaternary European distribution of Pseudopus based on its known fossil record on the continent and extant European range of P. apodus (based on Sillero et al. 2014). The current extraEuropean distribution of this latter species is not shown. Localities with multiple sites in the same area, such as Petersbuch in Germany,

fejfari is known from Czech Republic and Germany, from MN 3 to MN 8, but tentatively attributed material comes from older ages also (namely, MN 1/MN 2). It is interesting to note that this earlier occurrence comes from Sardinia (still undescribed and not figured remains from Oschiri; Venczel and Sanchiz 2006), fairly extending the possible geographical distribution of the species. Tentative identifications of $O$. fejfari are known from the MN 5 of the Austrian Korneuburg Basin too (Böhme 2002; Tempfer

are shown as a single point in the maps. White polygons represent uncertain or highly questionable occurrences. The maps also include occurrences of Ophisaurus moguntinus, Ophisaurus intermedius, and Propseudopus sp

2003). The stratigraphical and geographical distributions of the remains attributed to Ophisaurus holeci and Ophisaurus robustus (formerly Anguis robustus; Klembara 1979) are similar to those of $O$. fejfari, for they are known from a few Czech, southern German and, as far as $O$. robustus is concerned, Hungarian localities spanning a range of time included between MN 2 and MN 6/MN 7 (the former) and MN 3 and MN $7+8$ (the latter). It has to be noted, however, that a recent phylogenetic analysis by 
Klembara et al. (2017) recovered $O$. holeci more closely related to the Eocene taxon Ophisauriscus quadrupes than to other Ophisaurus, suggesting that this species might be a Miocene representative of a distinct Paleogene lineage of European anguids. Further analyses are needed to clarify this issue. Ophisaurus spinari has a longer evolutionary history, since it has its oldest occurrence in the Aquitanian (MN 2 of Wiesbaden-Amöneburg; Čerňanský et al. 2015) and the younger one in the Piacenzian (Capo Mannu D1 Local Fauna; Delfino et al. 2011; Klembara and Rummel 2018). Given that, $O$. spinari is the only European species of Ophisaurus that crossed the Miocene/Pliocene boundary, even if no other Pliocene occurrence is currently known. Geographically speaking, O. spinari is reported from Czech Republic, Germany, Slovakia and tentatively Austria during the Miocene and, as already mentioned above, from the Italian island of Sardinia during the Pliocene. Venczel and Hír (2013) reported Ophisaurus cf. O. spinari also from Hungary, in different $\mathrm{MN} 7+8$ to MN 9 sites of the Felsötárkány Basin. However, at least one of the remains they described, the parietal MMP 2009.532 (MMP = Municipal Museum of Pásztó), is assigned to $O$. robustus by Klembara and Rummel (2018). Given that, it is possible that at least some, if not all, of the other remains attributed to Ophisaurus cf. O. spinari belongs to the other species as well, and the possible occurrence of $O$. spinari in Hungary is here considered in need of a complete revision.

During the Early Pleistocene, another anguid lived on Meda Grande, one of the Medas Islands along the coast of northeastern Spain. This anguid, named Ragesaurus medasensis by Bailon and Augé (2012), is currently known only from its type locality. The taxonomic affinities of this taxon have not been thoroughly assessed yet, due also to the fact that it is represented only by an isolated dentary, but Čerňanský et al. (2016b) noted similarities between Ragesaurus and Ophisauromimus from the Oligocene of France and Germany. If this affinity is confirmed by further studies, Ragesaurus might represent the last, relict occurrence of a lineage of anguids present in Europe since at least the late Paleogene. Another new taxon might be represented by an isolated parietal from Gratkorn (late middle Miocene of Austria), attributed by Böhme and Vasilyan (2014) to $O$. spinari but clearly displaying a very different morphology (Klembara and Rummel 2018). A possible new anguid species, not linked to the above mentioned ones, is also reported from Sandelzhausen (MN 5) by Böhme (2010). Due to the very fragmentary nature of the specimens representing it, this species was left unnamed, even if similarities with Ophisaurus were highlighted.

All the previously mentioned anguid genera are members of the subfamily Anguinae, which clearly represents the great majority of anguid occurrences in Europe from the Neogene onwards. However, Anguinae might not be the only anguid subfamily to have been represented on the continent during the Miocene. Indeed, Böhme and Ilg (2003) listed members of the anguid subfamily Glyptosaurinae from Dolnice in Czech Republic (MN 4), Sandelzhausen in Germany (MN 5) and, with doubt, Mühlrüti Pt. 806 in Switzerland (MN 6). Glyptosaurs from Sandelzhausen have been previously mentioned as indeterminate Glyptosaurini by Böhme (1999a), whereas those from Dolnice are attributed to Melanosaurini by Böhme and Ilg. In his paper on the fossil lizards coming from Dolnice, Roček (1984) mentioned cf. Xestops sp. This attribution was based on a comparison with the material of Xestops weigelti (now Placosauriops weigelti; Augé and Sullivan 2006) from the middle Eocene of Geiseltal. Placosauriops is a member of the tribe Melanosaurini and therefore, the fossil material described by Roček might correspond to the indeterminate member of the tribe mentioned by Böhme and Ilg. Rather interesting, but at the same time rather doubtful, is the possible occurrence of an indeterminate member of the subfamily Gerrhonotinae from Vračević in Serbia (MN $7+8$; Jovanović et al. 2002). Gerrhonotine lizards, both extinct and extant species, are currently known only from North and Central America (Estes 1983; Böhme and Ilg 2003; Vitt and Caldwell 2009) and, given the general absence of other fossils of this subfamily from either Europe or other nearby countries, the Serbian occurrence is highly unlikely. However, given that the material mentioned by Jovanović and colleagues is neither described nor figured, this cannot be evaluated from their paper alone.

\section{Shinisauria}

Klembara (2008) described a new anguimorph based on cranial material and osteoderms coming from the early Miocene (MN 3) of Merkur North, naming it Merkurosaurus ornatus. He mentioned affinities with the Asian taxon Shinisaurus crocodilurus, and later Conrad et al. (2010) included Merkurosaurus in the clade Shinisauria. Subsequently, Merkurosaurus remains were reported also from MN 2 and MN 3 of Germany (Čerňanský et al. 2015; Villa and Delfino 2017). In particular, fossils from the MN 2 locality of Wiesbaden-Amöneburg were assigned to the type and only known species (Čerňanský et al. 2015). Given the clear similarities that Merkurosaurus shares with Shinisaurus, it has to be taken into account that also two occurrences of aff. Shinisaurus sp. from Weißenburg 6 (Oligocene/Miocene boundary, MN 1, Germany) and Wintershof West (MN 3, Germany) reported by Böhme and Ilg (2003) might instead represent the European taxon. This could be supported by the fact that other former 

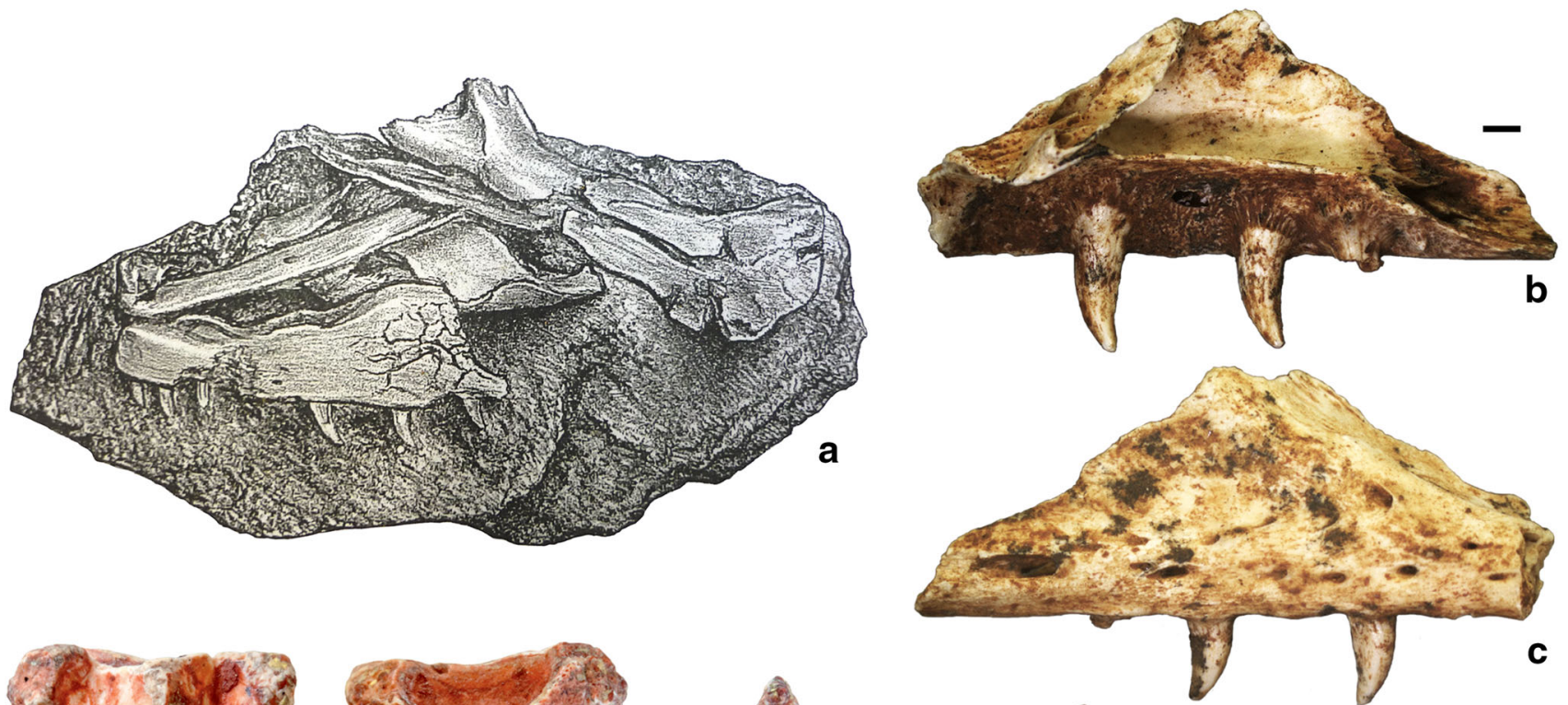
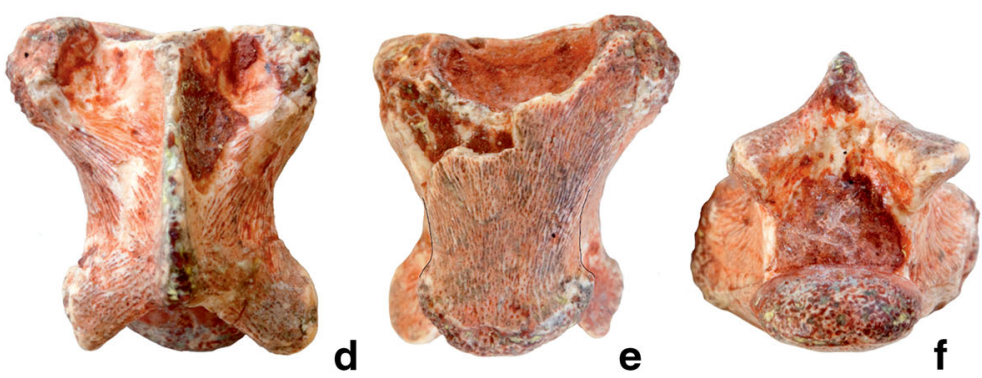
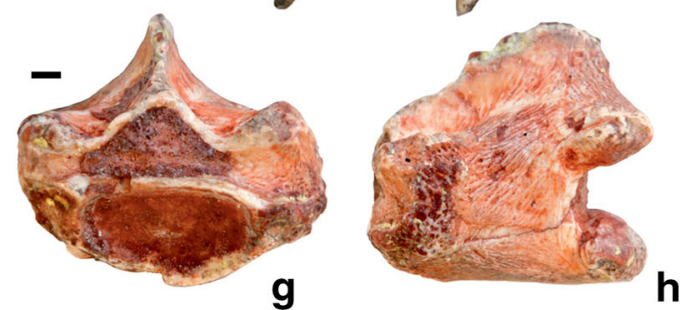

Fig. 11 Varanid remains from Europe: original figure of the fossil remains of Varanus marathonensis (a) from Pikermi, Greece, as reported by Weithofer (1888); right maxilla (UU TB5 1001; b, c) of Varanus sp. from Tourkobounia 5, Greece, in medial (b) and lateral (c) views (Georgalis et al. 2017b); holotypic trunk vertebra

occurrences mentioned by Böhme and Ilg (2003) of either cf. or aff. Shinisaurus sp. were later reallocated to Merkurosaurus (namely, those from Wiesbaden-Amöneburg and Stubersheim 3; Čerňanský et al. 2015; Villa and Delfino 2017), but in any case, this has to be confirmed after a direct study of the involved specimens.

Even though there are very few of them, the occurrences of a shinisaur in the early Miocene of Europe raise interesting questions on when this clade firstly enter the continent and why it apparently survived there only for such a short time and in such a restricted area (that is, Central Europe). The recent description of an isolated tail of an indeterminate crocodile-tailed lizard (clade Pan-Shinisaurus Smith and Gauthier, 2013, which is equivalent to Shinisauria Conrad, 2008) from the middle Eocene of Messel, Germany (Smith 2017), possibly hints for a distinctly older settlement of the clade in Europe. Nevertheless, due to the presence of a large stratigraphical gap between the Eocene and the Miocene occurrences and lacking a clear assessment of the phylogenetical relationships between the Messel specimen and Merkurosaurus, the alternative hypothesis of two distinct wave of
(IPS58437; d-h) of Iberovaranus catalaunicus from Can Mas, Spain, in dorsal (d), ventral (e), posterior (f), anterior (g), and left lateral (h) views, currently referred to Varanus sp. (Delfino et al. 2013). Scale bars equal $1 \mathrm{~mm}$. Drawing of $V$. marathonensis not to scale

colonization of the European territory by shinisaurians cannot be excluded a priori.

\section{Varanidae}

Monitor lizards (Fig. 11) are well known from the Miocene of Europe, showing then a very strong reduction in terms of abundance of remains during the Pliocene and the Pleistocene, when they ultimately disappeared from the continent. This reduction is linked to a narrowing of their former wide geographical distribution, since these anguimorph lizards show the same shrinking toward the south displayed by other squamates (Fig. 12).

Only one genus is currently reported from European Neogene and Quaternary localities: Varanus, whose stratigraphical distribution spans from the early Miocene to the Middle Pleistocene. A second, extinct genus, Iberovaranus (type species: Iberovaranus catalaunicus Hoffstetter, 1969) was reported in the past from early to middle Miocene localities of the Iberian Peninsula and tentatively Germany. However, as demonstrated by Delfino et al. (2013), the general morphology of the holotype of 

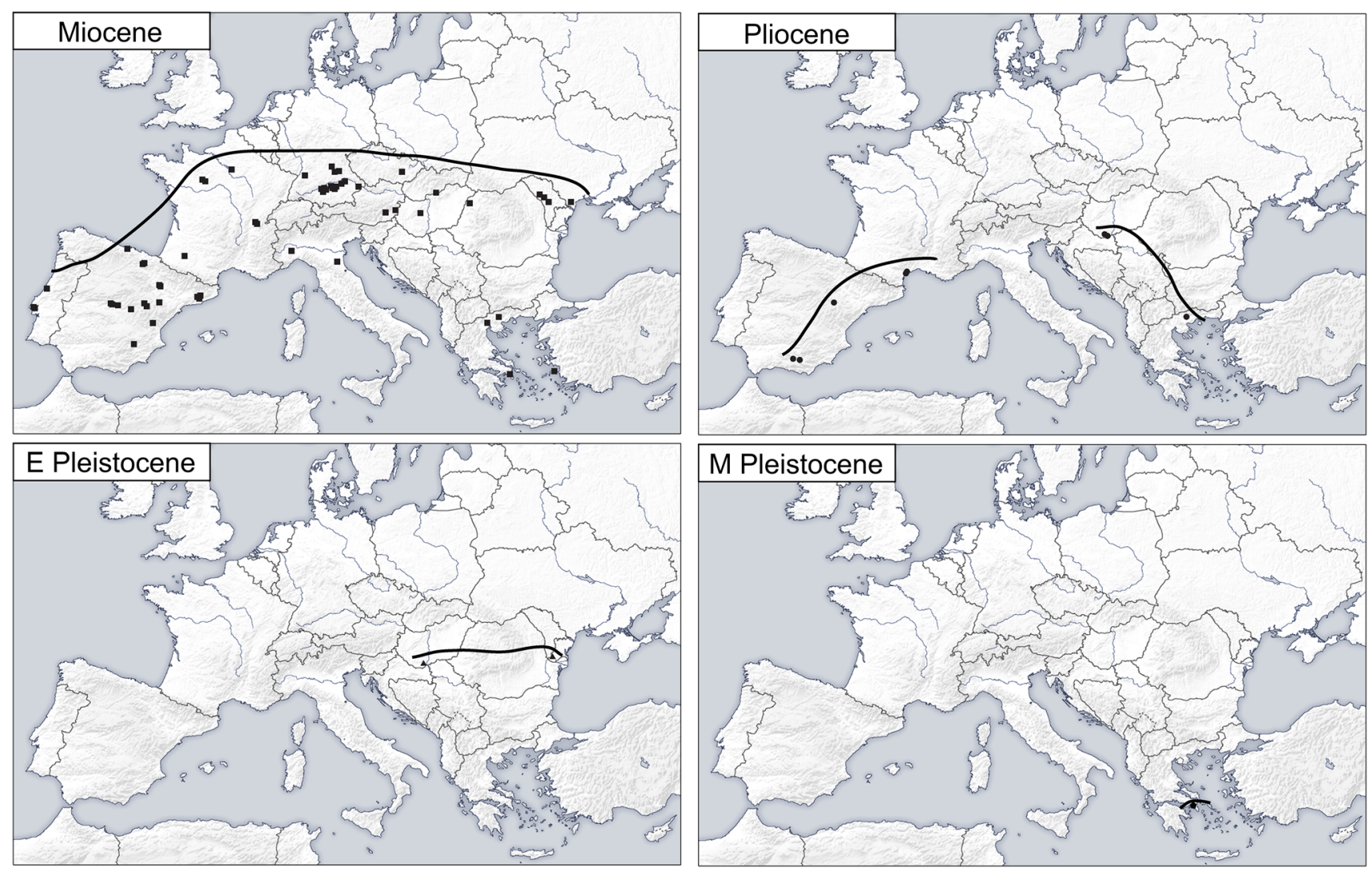

Fig. 12 Neogene and Quaternary European distribution of varanids based on their known fossil record on the continent. Localities with multiple sites in the same area, such as Petersbuch in Germany, are

I. catalaunicus, an isolated trunk vertebra coming from Can Mas near El Papiol (Vallès-Penedès Basin, NE Iberian Peninsula; Hoffstetter 1969; Fig. 11d-h), fits well within that of Varanus vertebrae and Iberovaranus has, therefore, to be considered a junior synonym of Varanus. Based on the very few varanid remains found in Can Mas (that is, just Hoffstetter's holotype trunk vertebra and a second, cervical vertebra), it is currently not possible to either confirm the validity of "Iberovaranus" catalaunicus as a distinct species of Varanus or synonymize it with another, already known species (Delfino et al. 2013). For the moment, the species is regarded as a nomen dubium and all past occurrences of Iberovaranus are assigned only to Varanus sp.

Besides the numerous occurrences unassigned to species, a few extinct species of Varanus have been named based on Miocene remains. In the early Miocene, two species are known. The recently described Varanus mokrensis is known only from its type locality in Czech Republic (Mokrá-Western Quarry, MN 4; Ivanov et al. 2018), whereas Varanus hofmanni has a wider distribution both in stratigraphical and possibly geographical terms. As a matter of fact, this latter species is reported in Germany

shown as a single point in the maps. White polygons represent uncertain or highly questionable occurrences

from the early-the middle Miocene (Burdigalian to Langhian; Roger 1898; Estes 1983; Böhme 2003; Böhme and Ilg 2003; Ivanov et al. 2018), but tentative attributions are known also from Austria, France, Hungary, Moldova and Spain (Hoffstetter 1969; Estes 1983; Böhme 2003; Böhme and Ilg 2003; Rage and Bailon 2005; Venczel 2006; Ivanov et al. 2018), reaching up to the late Messinian (MN 13). The validity of $V$. hofmanni, however, has been questioned, since its original description is based only on vertebral material found in Stätzling (middle Miocene of Germany; Roger 1898). Given that diagnostic significance at species level is uncertain for Varanus vertebrae compared to the more informative skull elements (Holmes et al. 2010; Delfino et al. 2013), V. hofmanni is considered a nomen dubium by some authors (Ivanov et al. 2018). The same argument holds true for three other species named from late Miocene vertebral remains: Varanus lungui (MN 9 of Moldova; Zerova and Chkhikvadze 1986), Varanus tyrasiensis (MN 9 of Moldova as well; Lungu et al. 1983) and Varanus semjonovi (MN 13 of Ukraine; Zerova and Chkhikvadze 1986). All these three species are reported only from their type localities. The late Miocene Varanus amnhophilis, on the other hand is based on cranial material 
(Conrad et al. 2012). This latter species is also known only from its type locality: namely, Q1 locality in the Mytilinii Formation (Samos, Greece).

The last named species is Varanus marathonensis (Fig. 11a), originally described by Weithofer (1888) and known from the late Miocene of Greece and possibly Spain (Weithofer 1888; Ivanov et al. 2018). Due to the rules of priority, Varanus atticus is a synonym of this species, because this name was created by Nopcsa (1908) to name a single vertebra coming from the type locality of V. marathonensis and firstly reported by Gaudry (1862) as possibly pertaining to Varanus, but later associated with the latter species by Weithofer (1888) himself. Varanus marathonensis is then reported from the Pliocene of Hungary. Part of the Hungarian material was originally attributed to the new species Varanus (= Monitor) deserticolus by Bolkay (1913), together with anguid remains. The varanid part of the type material of $V$. deserticolus was later linked to V. marathonensis (Estes 1983; Georgalis et al. 2017b). In spite of this, Jánossy (1986) still mentioned $V$. deserticolus from the Pliocene and even the Early Pleistocene of Hungary, without figuring or describing the findings. Given that, even though the Pliocene record could indeed represent $V$. marathonensis (the locality mentioned by Jánossy, Csarnóta, indeed yielded the latter taxon according to other authors; Estes 1983; Ivanov et al. 2018), its Pleistocene report is here considered dubious pending a revision of the material. The possible Middle Pleistocene occurrence of $V$. marathonensis from Petralona Cave in Greece (Sickenberg 1971; the specific name is incorrectly spelled in the paper) is also questionable, since figures and description of the specimens are lacking and the material is currently lost (Georgalis et al. 2017b). It is interesting to note that this finding was attributed to Varanus intermedius by Kretzoi and Poulianos (1981). This could be a wrong generic allocation of the species Ophisaurus intermedius, currently considered a synonym of Pseudopus pannonicus. The alternative possibility that the fossil material from Petralona Cave indeed pertained to a large anguid should, therefore, not be discounted.

Adding to the two above-mentioned uncertain occurrences of $V$. deserticolus and Varanus aff. V. marathonensis, there are two other Pleistocene mentions of Varanus. The oldest and less certain one is from the Gelasian of Ukraine (Kotlovina; Böhme and Ilg 2003), whereas the youngest one is from the latest Early/earliest Middle Pleistocene Greek site of Tourkobounia 5 (Georgalis et al. 2017b; Fig. 11b-c). An even younger occurrence would have been the Varanus lower jaw reported by Morelli (1891) from Late Pleistocene layers of the Arene Candide Cave, in northern Italy. The specimen is currently lost, but Delfino (2002) discarded the possibility that it represented a varanid based on Morelli's drawing. Lizards whose size is comparable with Morelli's specimen are still present not so far from the Arene Candide Cave (namely, the lacertid Timon lepidus), but some differences between the lower jaw and the standard lacertid morphology seem to be present. Because of this, a non-lacertilian nature of the specimen cannot be excluded, even though Delfino (2002) cautiously considered it as an indeterminate lizard pending a possible review following its rediscovery. It has been given that the above-mentioned Tourkobounia findings mark the last known occurrence of the family in Europe, before its disappearance from the continent.

\section{Other lizards}

A large number of remains coming from numerous Neogene and Quaternary localities in Europe are assigned to indeterminate acrodontans, scincomorphs, anguimorphs or generically lizards. In most cases, these fossils represent skeletal elements that are either too fragmentary or considered undiagnostic, but might possibly be associated with other lizard occurrences coming from the same localities. Nevertheless, more complex situations are also present. The case of the Arene Candide varanid is reported above, but a similar problematic occurrence is the presumed Uromastyx tibia mentioned by Mangili (1980) from the Late Pleistocene of Simonelli Cave, in Crete. This occurrence, referred to as Uromastyx spinipes (= Uromastyx aegyptia), cannot be confirmed, since the whereabouts of the fossil studied by Mangili are unknown and there are no figures in his paper. Caloi et al. (1986) referred it to ?Agama sp., but provided no justification for their assignment. Taking also into account the presence of large-sized lacertids in the Pleistocene of Mediterranean islands, Delfino et al. (2008) proposed to consider the tibia from Crete only as an indeterminate lizard waiting for a formal revision.

A fragmentary dentary of the amblyodont scincomorph Hugueneysaurus globidens has been found at Moissac 1 (Aquitanian, MN 1, of France; Augé 2005). Hugueneysaurus, known also from two other French localities late Oligocene in age (Coderet and La Colombière; Augé 2005), has a dentary morphology that is lacertid like on the whole, but seems to also display a supposed synapomorphy of Scincoidea (that is, a labial cover of the coronoid by the dentary; Augé 2005). This complicates its assignment to either one of the two scincomorph clades: Lacertoidea and Scincoidea. Subpleurodont posterior teeth and a strongly narrow anterior portion of the Meckelian fossa might also support scincoid affinities (Augé 2005). In any case, $H$. globidens represents another amblyodont taxon inhabiting Europe between the Paleogene and the beginning of the Neogene, adding to the amblyodont lacertids reported above. Among these amblyodont forms, H. globidens is 

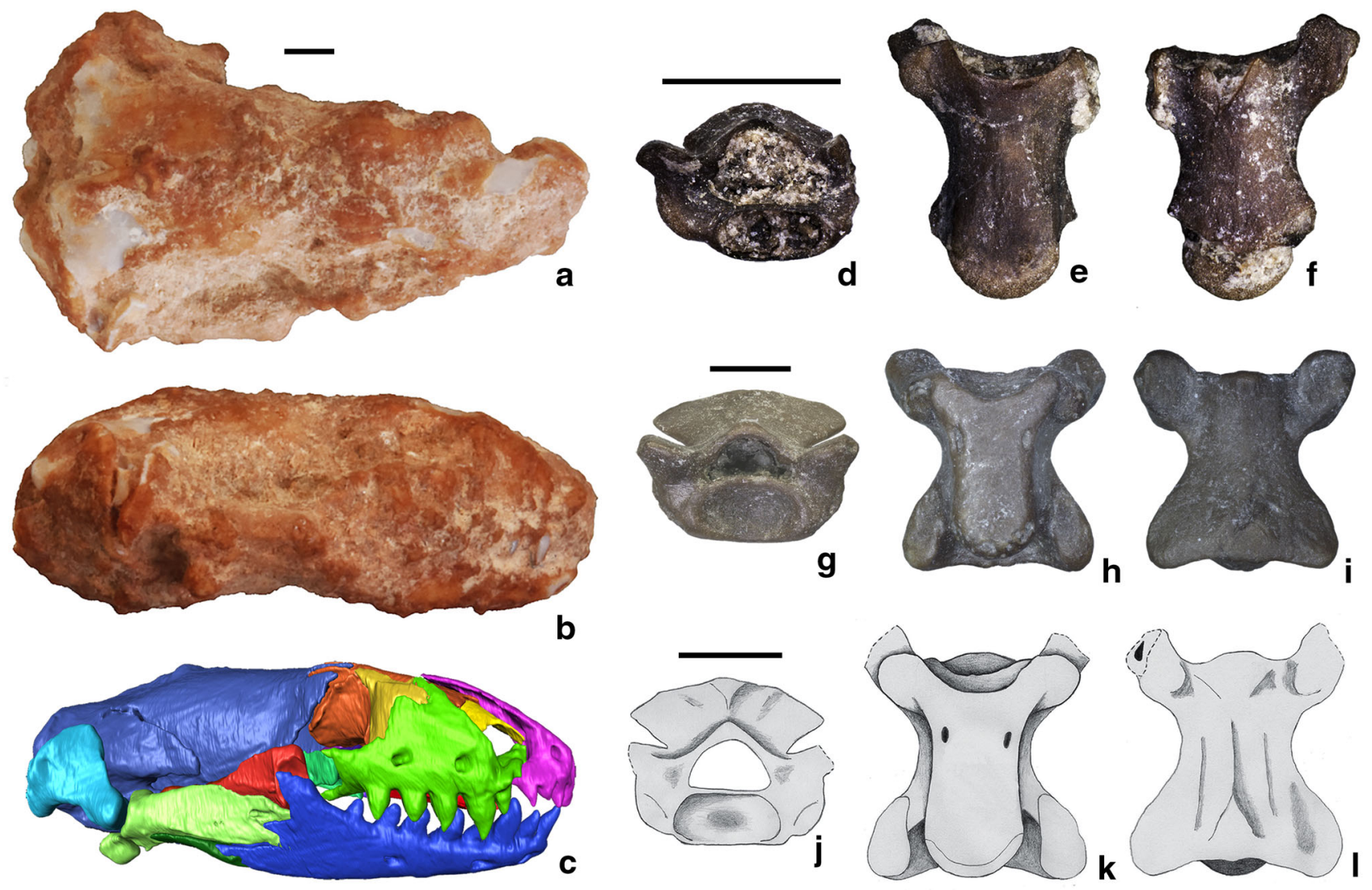

Fig. 13 Amphisbaenian remains from Europe: holotypic skull (IPS60464; a, b) and its virtual model (c) of Blanus mendezi from Abocador de Can Mata, Spain, in dorsal (a) and lateral (b, c) views (Bolet et al. 2014); trunk vertebra (UU PL 733; d-f) of Amphisbaenia indet. from Plakias, Greece, in anterior (d), ventral (e), and dorsal (f) views (Georgalis et al. 2016b); trunk vertebra (UU SP4 501; g-i)

rather interesting in being only one of the very few taxa crossing the Oligocene/Miocene boundary, together with Mediolacerta.

The genus Sauromorus was erected by Pomel (1853), who included two species in it: Sauromorus ambiguus and Sauromorus lacertinus. According to the author, both these species come from early Miocene sites in France: from Langy and Marcouin (or Marcoin) the former and from Langy only (not Marcoin as reported by Estes 1983) the latter. There is a certain degree of uncertainty on the family in which this genus has to be included, with all Scincidae, Anguidae and Lacertidae that have been taken into account in the past (Zittel 1889; Nopcsa 1908; Hoffstetter 1944; Estes 1983). Nevertheless, the type material is lost since at least the first half of the twentieth century (Hoffstetter 1944) and this issue cannot be checked, given also that Pomel (1853) did not figure his specimens. Therefore, both species of Sauromorus should be referred to as nomina dubia, as already pointed out by Estes (1983). of Amphisbaenia indet. from Spilia-4, Greece, in anterior (g), ventral (h), and dorsal (i) views (Georgalis et al. 2018); trunk vertebra (K22/ $\mathrm{R} / 1 ; \mathbf{j}-\mathbf{l})$ of Amphisbaenia indet. from $\mathrm{K} 22$, Italy, in anterior $(\mathbf{j})$, ventral (k), and dorsal (l) views (Delfino 2003). Scale bars equal 1 $\mathrm{mm}$

\section{Amphisbaenia}

The evolutionary history of worm lizards in Europe dates back at least to the early Paleocene (Augé 2012; Folie et al. 2013) and these squamates are rather well known from Neogene and Quaternary deposits on the continent (Fig. 13). Their Miocene record spans most of Europe, whereas they are already confined to Mediterranean countries from the Pliocene onward (Delfino 1997b; Fig. 14). Except for a few Italian localities, the Pleistocene/ Holocene occurrences come only from the Iberian Peninsula, where most of the extant European amphisbaenians live today (Fig. 14).

The most common remains of this group of squamates found on the continent are vertebrae (Fig. 13d-1), which are not considered significant from a diagnostic point of view even at the family level (Estes 1983). Because of that, it is possible that most indeterminate members of the family Amphisbaenidae mentioned in the past from European deposits are better identifiable as indeterminate 

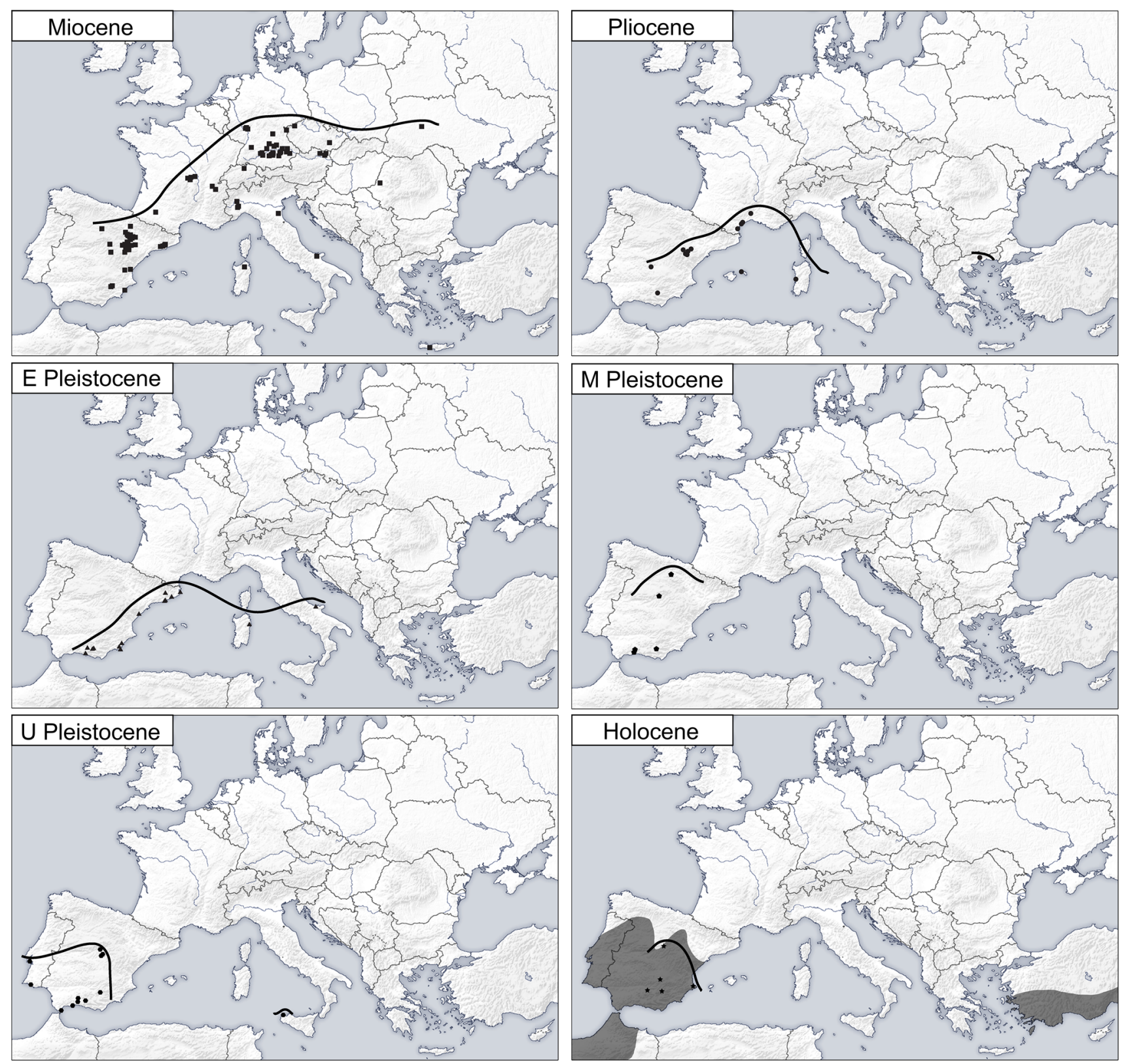

Fig. 14 Neogene and Quaternary European distribution of amphisbaenians based on their known fossil record on the continent. Localities with multiple sites in the same area, such as Petersbuch in Germany, are shown as a single point in the maps. The current

amphisbaenians, representing the past trend to attribute all amphisbaenian remains to the only worm lizard family known to live in Europe back then (prior to the split of Blanidae by Kearney 2003). Currently, worm lizard remains yielded by Neogene and Quaternary localities in Europe that have been confidently identified below family level are assigned to Blanidae.

Possible occurrences of the problematic species Omoiotyphlops edwardsi are reported from three Miocene localities in France: Sansan, La-Grive-Saint-Alban and

distribution of Blanus, the only extant European amphisbaenian genus, in Europe and nearby countries is also shown in the Holocene map

Saint-Gérand-le-Puy. These occurrences were originally mentioned by Hoffstetter (1942) and later by Estes (1983) and Schleich (1985). Omoiotyphlops edwardsi is as a synonym of Omoiotyphlops priscus, a species of presumed scolecophidian snake named by Rochebrune (1884) from the Phosphorites du Quercy. The name $O$. edwardsi (reported by Estes 1983) most probably originates from the mislabeling of the $O$. priscus figures, which were labeled as "Typhlops edwardsi" by Rochebrune himself (see Hoffstetter 1942). Later, Hoffstetter (1942) demonstrated that 
the type vertebrae of $O$. priscus belong in fact to an amphisbaenian, moving Rochebrune's species to this group though briefly questioning the validity of the genus. The same author then mentioned remains similar to the Quercy species from the three above-mentioned French localities, providing no descriptions. However, being based on nondiagnostic remains (i.e., vertebrae), O. priscus is currently considered a nomen dubium (Estes 1983; Augé 2012). Accordingly, possible Neogene French occurrences of this species are most probably better referred to as indeterminate amphisbaenians.

The best represented amphisbaenian genus in the Neogene and Quaternary fossil record of Europe is Blanus, but a second genus, Palaeoblanus, is present in the Miocene of the continent. The type and only known species of the latter genus, Palaeoblanus tobieni, was described by Schleich (1988) based on fossils coming from the Aquitanian of Weisenau near Mainz, in Germany. The same author also described remains found in the roughly coeval locality Budenheim, also located near Mainz. The species was later reported from Stubersheim 3 (Böhme 1999b) and tentatively from Unterempfenbach 1b (Böhme 2003; Böhme and Ilg 2003), extending its German record up to the early Burdigalian and possibly the Langhian. Palaeoblanus tobieni, therefore, has a rather restricted distribution during the Neogene, both geographically and stratigraphically. Remains referred only to the genus, on the other hand, also occur in France during the Aquitanian and the Langhian/ Serravallian (Augé and Rage 2000; Böhme 2003; Böhme and Ilg 2003), in Spain from the Burdigalian to the Langhian (maybe Serravallian, if the attribution to aff. Palaeoblanus sp. of remains from Las Planas $5 \mathrm{~L}$ is confirmed; Böhme and Ilg 2003) and in Italy in the late Miocene/possibly early Pliocene (Delfino 2002, 2003, 2013). Moreover, Böhme (2010) assigned a premaxilla and a fragmentary dentary from Sandelzhausen (late Burdigalian of Germany) to a possible second species of Palaeoblanus, without naming it. However, it has to be noted that Augé (2012) recently questioned the validity of $P$. tobieni, stating that its diagnostic features could be plesiomorphic within amphisbaenians.

Blanus is reported since the beginning of the Miocene. Four extinct species are known, all Miocene in age. The oldest ones are Blanus gracilis and Blanus thomaskelleri. Blanus gracilis was originally described as Omoiotyphlops gracilis by Roček (1984), its type material coming from the MN 4 of Dolnice in Czech Republic. As reported above, Omoiotyphlops is not a valid genus and so this species cannot be included in it. Both Venczel and Sanchiz (2006) and Venczel and Ştiucă (2008) referred it to Blanus, while reporting $B$. gracilis from the MN 1/MN 2 of Oschiri, in Sardinia, and Blanus cf. B. gracilis from the MN 8 of Taut, in Romania, respectively. Bolet et al. (2014) recently placed B. gracilis (not on the basis of a phylogenetic analysis) well nested inside Blanus, as part of the eastern clade of the genus together with Blanus strauchi. Blanus thomaskelleri was found in Wiesbaden-Amöneburg (Aquitanian, MN 2/MN 3, of Germany; Čerňanský et al. 2015), but an isolated dentary coming from the Burdigalian (MN 3) of Merkur North, in Czech Republic (previously reported as Blanus sp.; Čerňanský and Venczel 2011), has been later assigned to this species (Čerňanský et al. 2015). Another species, Blanus antiquus, is known only from the late early to middle Miocene of Austria and Germany (Schleich 1985; Böhme 1999b, 2003; Böhme and Ilg 2003; Miklas-Tempfer 2003). Blanus antiquus has sometimes been considered a synonym of $B$. gracilis (e.g., Böhme 1999b; Augé and Rage 2000), but Bolet et al. (2014) supported the separation of the two species, placing $B$. antiquus as a basal taxon sister to all other Blanus in their figured evolutionary tree of the genus. In the end, a wellpreserved skull from the middle Miocene of Abocador de Can Mata, one of the localities of the Vallès-Penedès Basin in Catalunya (northeastern Iberian Peninsula), has been attributed to the new species Blanus mendezi (Fig. 13a-c), which is considered as the most basal taxon of the western Blanus clade (Bolet et al. 2014). This finding, together with the inclusion of $B$. gracilis in the eastern clade (if confirmed with a formal phylogenetic analysis), suggests an early Miocene or even pre-Miocene dating of the separation between the two main clades of Blanus currently recognized on molecular bases (see Sindaco et al. 2014, 2015, for the molecular data supporting these two clades).

Possible representatives of extant Blanus species are firstly reported in the Pliocene. As a matter of fact, Blanus cinereus or morphologically similar forms have been found in the middle to late Pliocene of both France (Bailon 1991; García-Porta et al. 2002; Böhme and Ilg 2003; Blain 2005, 2009; Bailon and Blain 2007) and Spain (Barbadillo et al. 1997; Crespo 2001; García-Porta et al. 2002; Böhme and Ilg 2003; Blain 2005, 2009). Later, during the Pleistocene and Holocene, this species is found only in the Iberian Peninsula. Currently, two Blanus species live in the Iberian Peninsula: B. cinereus and Blanus vandellii. Blanus mariae, described by Albert and Fernández (2009) after the recognition of two distinct genetic lineages in the Peninsula, was recently synonymized with $B$. cinereus by Ceríaco and Bauer (2018) due to a misidentification of the type locality of the latter species by Albert and Fernández (2009). Because of this, the genetic lineage that was formerly considered to represent $B$. cinereus, found in the central and eastern portions of the Iberian Peninsula, was referred by Ceríaco and Bauer (2018) to the new species $B$. vandellii; whereas, the southern lineage (formerly representing $B$. mariae) is now referred to B. cinereus. Since it 
appears rather difficult, if possible at all, to distinguish all bones of $B$. cinereus from those of $B$. vandellii (Villa et al. $2017 \mathrm{~b}$ ), it is also possible that at least some of these remains pertain to the latter species. Amphisbaenians are currently absent from Italy, showing a disjunct range in northern Mediterranean countries today. However, they were indeed present in the Apennine Peninsula and on Italian islands until the Pleistocene. They have been found in the Early Pleistocene of Apulia (Cava dell'Erba at Pirro Nord), in the early and Late Pleistocene of Sardinia (Cava VI 3 and Cava VI Banco 6 at Monte Tuttavista) and in the Middle/Upper Pleistocene of Sicily (K 22, near San Vito lo Capo). The Apulian remains are assigned to an indeterminate species of Blanus (Delfino and Bailon 2000; incorrectly reported as Blanus cf. B. strauchi by Holman, 1998); whereas, only isolated worm lizard vertebrae are known from the other Italian Pleistocene localities (Delfino 2003; Rook et al. 2003; Abbazzi et al. 2004).

\section{Discussion}

The fossil record of lizards and worm lizards dating back to the Neogene and Quaternary in Europe is extensive. It documents the presence on the continent of at least 12 families during the last 23 million years. Nine of these families still inhabit Europe today, whereas three (varanids, the indeterminate shinisaur family represented by Merkurosaurus and possibly cordylids) are locally extirpated. No extinct lizard family is represented in Europe during Neogene and Quaternary. If compared with Paleogene faunas, a marked drop in diversity at family level is recognizable, with the disappearance of at least four lizard and one worm lizard families. Eolacertids, helodermatids, iguanids and palaeovaranids are all reported from a number of Paleogene sites in Europe (Estes 1983; Augé 2003, 2005; Klembara and Green 2010; Augé and Pouit 2012; Bolet and Evans 2013b; Čerňanský et al. 2016b; Smith and Scanferla 2016; Bolet 2017; Georgalis 2017; Čerňanský and Smith 2018; Smith et al. 2018), but they have no record on the continent following the Oligocene/ Miocene boundary. Adding to these, worm lizards of the family Polyodontobaenidae are known only from few localities in the Paleocene of France and Belgium (Folie et al. 2013). Augé (2005) also mentioned a possible teiid, Brevisaurus smithi, from the late Eocene/Oligocene of France, possibly taking to five the number of lizard families that went either extinct or locally extirpated from Europe after the Paleogene.

Most of the families that are present in the Neogene, on the other hand, were already present in the Paleogene, even though with different lineages in some cases. Varanids, for example, were represented by Saniwa before the
Oligocene/Miocene boundary; whereas, Neogene and Quaternary remains are attributed to the genus Varanus only (Hoffstetter 1943; Estes 1983; Augé 2005; Delfino et al. 2013; Georgalis et al. 2017b; Ivanov et al. 2018). Saniwa is the sister clade to Varanus (e.g., Conrad et al. 2008, 2010, 2012; Ivanov et al. 2018), but European species of the latter genus are usually recovered well nested inside crown Varanus (Conrad et al. 2012; Ivanov et al. 2018) and most likely are not direct descendants of the former. Only chamaeleons, phyllodactylids and sphaerodactylids are not reported from sites dating back to preMiocene times. However, the absence of the two gekkotan families might be also due to the very scarce record of fossil geckos and the difficulty of understanding the affinities of certain Paleogene taxa (Daza et al. 2014). Future findings of better-preserved gekkotan material from the Paleogene of Europe might help to clarify this issue. Chamaeleons, on the other hand, might have been truly absent from Palaeogene Europe given that remains from that period have never been found.

The significant change in the lizard fauna that occurred between the Paleogene and the Neogene is paralleled in snake assemblages (Rage 2013). It may be at least partially linked with an environmental deterioration impacting Europe during the late Oligocene. Rage and Szyndlar (2005) suggested that the drier and cooler climates characterizing this time period had an evident effect on booid snakes, which are less diverse and smaller in size in the MP 29 - MN 2 interval. This effect was so significant that the two authors even coined the term "Dark period of booid snakes" to refer to it. Similar dynamics seem to have influenced other squamates as well (Rage 2013). Diversity and size then rose again in the following assemblages, with the arrival of new immigrants (such as chamaeleons and Varanus; Georgalis et al. 2016a; Ivanov et al. 2018) and the appearance of large-sized taxa (such as giant varanids; Conrad et al. 2012). These immigration events were probably triggered by the warm and humid Miocene Climatic Optimum (starting in MN 3), as well as by the onset of stable connections between Eurasia and Africa (Böhme 2003; Rage 2013; Georgalis et al. 2016a).

As a whole, the overview of the post-Miocene records of European lizards confirms what previously stated by other authors, in terms of evolutionary dynamics (see e.g., Rage 2013; Blain et al. 2016; Georgalis et al. 2017b). As a matter of fact, the lizard fauna of Europe underwent a progressive impoverishment driven mainly by the Quaternary glacial cycles and, in this context, the most thermophilic taxa displayed a southward shrinking of their European range, eventually leading to their local extirpation in some cases. Agamids, varanids (Fig. 12) and amphisbaenians (Fig. 14) are all well-illustrative cases of this. This further proves the important role as refugia for the herpetofauna played by 
Table 1 Stratigraphic distribution of the Neogene and Quaternary lizards in the European fossil record

\begin{tabular}{|c|c|c|c|c|c|c|c|c|c|}
\hline Taxon & E Mio & M Mio & L Mio & E Plio & L Plio & E Plei & M Plei & L Plei & Holo \\
\hline Agama/Agamidae & $\mathrm{x}$ & $\mathrm{x}$ & $\mathrm{x}$ & $\mathrm{x}$ & $\mathrm{x}$ & $\mathrm{x}$ & $\mathrm{x}$ & & \\
\hline Chamaeleo & $\mathrm{x}$ & $\mathrm{X}$ & & & & & & & $\mathrm{x}$ \\
\hline Hemidactylus & & & & & & & $\mathrm{x}$ & $\mathrm{x}$ & $\mathrm{x}$ \\
\hline Tarentola & & & & & cf. & $\mathrm{x}$ & $\mathrm{x}$ & $\mathrm{x}$ & $\mathrm{x}$ \\
\hline Euleptes & $\mathrm{x}$ & $\mathrm{x}$ & cf. & & & & & & \\
\hline Gerandogekko & $\mathrm{x}$ & & $\mathrm{x}$ & & & & & & \\
\hline Palaeogekko & & $\mathrm{x}$ & & & & & & & \\
\hline Acanthodactylus & & & & $\mathrm{x}$ & & $\mathrm{x}$ & $\mathrm{x}$ & $\mathrm{x}$ & $\mathrm{x}$ \\
\hline Amblyolacerta & $\mathrm{x}$ & $\mathrm{x}$ & $?$ & & & & & & \\
\hline Archaeolacerta & & & & & $\mathrm{x}$ & $\mathrm{x}$ & $\mathrm{x}$ & $\mathrm{x}$ & $\mathrm{x}$ \\
\hline Dalmatolacerta & & & & & & $\mathrm{x}$ & & & \\
\hline Edlartetia & cf. & $\mathrm{x}$ & $\mathrm{x}$ & & & & & & \\
\hline Eremias & & & & & & & $\mathrm{x}$ & $\mathrm{x}$ & $\mathrm{x}$ \\
\hline Janosikia & $\mathrm{x}$ & $\mathrm{x}$ & & & & & & & \\
\hline Lacerta & $\mathrm{x}$ & $\mathrm{x}$ & $\mathrm{x}$ & $\mathrm{x}$ & $\mathrm{x}$ & $\mathrm{x}$ & $\mathrm{x}$ & $\mathrm{x}$ & $\mathrm{x}$ \\
\hline Ligerosaurus & & $\mathrm{x}$ & & & & & & & \\
\hline Maioricalacerta & & & & & & $\mathrm{x}$ & & & \\
\hline Mediolacerta & $\mathrm{x}$ & & & & & & & & \\
\hline Miolacerta & $\mathrm{x}$ & $\mathrm{x}$ & $\mathrm{x}$ & & & & & & \\
\hline Ophisops & & & & & & $\mathrm{x}$ & & & \\
\hline Podarcis & & & & $\mathrm{x}$ & $\mathrm{X}$ & $\mathrm{x}$ & $\mathrm{x}$ & $\mathrm{x}$ & $\mathrm{x}$ \\
\hline Psammodromus & & & & $\mathrm{x}$ & $\mathrm{x}$ & $\mathrm{x}$ & $\mathrm{x}$ & $\mathrm{x}$ & $\mathrm{x}$ \\
\hline Timon & & & & & & $\mathrm{x}$ & $\mathrm{x}$ & $\mathrm{x}$ & $\mathrm{x}$ \\
\hline Zootoca & & & & $\mathrm{x}$ & $\mathrm{x}$ & $\mathrm{x}$ & $\mathrm{x}$ & $\mathrm{x}$ & $\mathrm{x}$ \\
\hline Ablepharus & & & & & & $\mathrm{x}$ & $\mathrm{x}$ & $\mathrm{x}$ & $\mathrm{x}$ \\
\hline Bavariascincus & $\mathrm{x}$ & & & & & & & & \\
\hline Chalcides & & $\mathrm{x}$ & $\mathrm{x}$ & $\mathrm{x}$ & $\mathrm{x}$ & $\mathrm{x}$ & $\mathrm{x}$ & $\mathrm{x}$ & $\mathrm{x}$ \\
\hline Eumeces & $\mathrm{x}$ & aff. & & & & & & & \\
\hline Mabuya & aff. & $\mathrm{x}$ & & cf. & & $\mathrm{x}$ & & & \\
\hline Trachylepis & & & & & & $\mathrm{x}$ & & & \\
\hline Tropidophorus & & $\mathrm{x}$ & & & & & & & \\
\hline Bavaricordylus & $\mathrm{x}$ & $\mathrm{x}$ & & & & & & & \\
\hline Palaeocordylus & $\mathrm{x}$ & & & & & & & & \\
\hline Hugueneysaurus & $\mathrm{x}$ & & & & & & & & \\
\hline Anguis & $\mathrm{x}$ & $\mathrm{x}$ & $\mathrm{x}$ & $\mathrm{x}$ & $\mathrm{x}$ & $\mathrm{x}$ & $\mathrm{x}$ & $\mathrm{x}$ & $\mathrm{x}$ \\
\hline Ophisaurus & $\mathrm{x}$ & $\mathrm{x}$ & $\mathrm{x}$ & $\mathrm{x}$ & $\mathrm{x}$ & $\mathrm{x}$ & $\mathrm{x}$ & $\mathrm{x}$ & \\
\hline Pseudopus & $\mathrm{x}$ & $\mathrm{x}$ & $\mathrm{x}$ & $\mathrm{x}$ & $\mathrm{x}$ & $\mathrm{x}$ & $\mathrm{x}$ & $\mathrm{x}$ & $\mathrm{x}$ \\
\hline Ragesaurus & & & & & & $\mathrm{x}$ & & & \\
\hline Glyptosaurinae & $\mathrm{x}$ & $?$ & & & & & & & \\
\hline Gerrhonotinae & & $?$ & & & & & & & \\
\hline Shinisaurus & aff. & & & & & & & & \\
\hline Merkurosaurus & $\mathrm{x}$ & & & & & & & & \\
\hline Varanus & $\mathrm{x}$ & $\mathrm{x}$ & $\mathrm{x}$ & $\mathrm{x}$ & $\mathrm{x}$ & $\mathrm{x}$ & $\mathrm{x}$ & & \\
\hline Sauromorus & $\mathrm{x}$ & & & & & & & & \\
\hline Blanus & $\mathrm{x}$ & $\mathrm{x}$ & $\mathrm{x}$ & $\mathrm{x}$ & $\mathrm{x}$ & $\mathrm{x}$ & $\mathrm{x}$ & $\mathrm{x}$ & $\mathrm{x}$ \\
\hline Palaeoblanus & $\mathrm{x}$ & $\mathrm{x}$ & $\mathrm{x}$ & $\mathrm{x}$ & & & & & \\
\hline Omoiotyphlops & $\mathrm{x}$ & $\mathrm{x}$ & $\mathrm{x}$ & & & & & & \\
\hline
\end{tabular}

E Mio early Miocene, E Plei Early Pleistocene, E Plio early Pliocene, Holo Holocene, L Mio late Miocene, L Plei Late Pleistocene, L Plio late Pliocene, M Mio middle Miocene, M Plei Middle Pleistocene 
southern European peninsulae. Future studies may shed further light on the role of the range changes in shaping the diversity through time of southern areas. If these changes are just represented by the southward shrinkage of the range of a certain assemblage that is widespread throughout Europe, then southern peninsulae are expected to maintain a roughly constant diversity. On the other hand, in the case of the southward dispersal of central European taxa, then the southern areas would see either an increase in the local diversity due to the concentration of taxa or an increasing competition that would lead to a change in the taxonomic composition of the fauna. Nevertheless, in spite of the significant changes occurring during the last 23 million years, it appears clear that the roots of the modern European lizard fauna are found deep in the Neogene. When considering lower taxonomic levels, extant genera are found since the beginning of the Miocene (Table 1) and, at least in some cases, these occurrences may even be related to extant species or species group (Čerňanský 2010b; Venczel and Hír 2013). The generally scarce knowledge we have of the comparative osteology of European lizards (Villa et al. 2017a) is possibly conditioning our understanding of the evolutionary history of these forms closely related to extant taxa between their earliest occurrences and modern times. Future revisions of fossil remains previously attributed to wastebasket taxa such as Agama s.l., Lacerta s.l. and also Podarcis sp. could be of help in better tracing this evolutionary history, if carried out in the context of a wider osteological knowledge.

A better sampling in those time ranges for which the fossil record of lizards is insufficient, such as Pliocene and Holocene, would also be highly desirable. Potentially interesting localities are indeed present (e.g., the Italian Holocene site of Tenuta Zuccarello, from which more than 8000 remains of amphibians and reptiles, including a high number of lizard bones, were recovered; Villa et al. 2018d), but their palaeoherpetofaunas usually remain unstudied for long times. Other sites that were never excavated expressly for the recovery of microvertebrate remains could also yield interesting finds, if proper sampling methods are used in future field campaigns. This would help to fill a significant gap in our knowledge of how lizard assemblages evolved after the Neogene (Pliocene) and how they reacted to the increasing development of human societies (Holocene).

\section{Conclusions}

Our review of the fossil lizards and worm lizards in the Neogene and Quaternary of Europe highlighted a vast fossil record, both in terms of localities that have yielded remains of these reptiles and of taxa recovered in such localities. Lizards are confirmed as an important component of the past herpetofauna of the continent, as it is still the case for the modern one. A marked faunistic change is detectable when comparing the Neogene lizard fauna with the Paleogene one, but the diversity remains rather high after the Oligocene/Miocene boundary, with at least 12 different families represented in Europe. Similar to other reptiles, a drop in diversity occurred later, leading to the current, impoverished fauna.

Considered together, 45 lizard and worm lizard genera and more than 90 species are currently reported as fossil in the time range contemplated herein. Nevertheless, the validity of at least some of these taxa is questionable and should be tested with a thorough revision of the type material (when still available). Taxa that are considered closely related to extant species (or species complexes) are reported since the beginning of the Miocene, suggesting that the origins of the modern lizard fauna can be traced back to that moment in time.

Despite the large number of species identified in the record, there is still a lot of materials that, although being mentioned in online databases or in publications not directly focused on it, remain either completely unpublished or in need of being thoroughly described and identified following the currently available criteria and data. Because of that, as well as of the need of a better sampling in key periods (such as Pliocene and Holocene), a lot of work still needs to be done by palaeoherpetologists to have a clearer understanding of the palaeontological history of lizards and worm lizards (and the herpetofauna in general) in Europe during the last 23 million years.

Acknowledgements This overview was part of the Ph.D. thesis of one of us (A.V.) at the University of Torino. It greatly benefited from discussions with Aaron Bauer (Villanova University), Arnau Bolet (University of Bristol), Georgios Georgalis (University of Fribourg), Emanuel Tschopp (American Museum of Natural History, New York City) and Davit Vasilyan (JURASSICA Museum, Porrentruy). Two reviewers, Krister Smith (Senckenberg Research Institute, Frankfurt am Main) and Andrej Čerňanský (Comenius University, Bratislava), are thanked for useful comments on a previous version of this article. We would also like to thank the editor Daniel Marty. A.V. thanks Daniele Arobba, Andrea De Pascale and all the staff at Museo Archeologico del Finale (Finale Ligure) for their assistance while studying Ligurian fossil lizards, including the strange Hemidactylus from Valdemino. Oliver Rauhut (Bayerische Staatssammlung für Paläontologie und Geologie, Munich), Caterinella Tuveri (Soprintendenza Archeologia, Belle Arti e Paesaggio per le prov. di Sassari e Nuoro, Nuoro), Alexander Kupfer and Erin Maxwell (Staatliches Museum für Naturkunde, Stuttgart) kindly gave access to the collections under their care and helped while studying them. Visits to the Bayerische Staatssammlung für Paläontologie und Geologie (Munich) were supported by an EAVP Research Grant from the European Association of Vertebrate Palaeontologists to A.V. Arnau Bolet and David M. Alba (Institut Català de Paleontologia Miquel Crusafont, Sabadell) kindly allowed us to use their photos and the 3D model of B. mendezi in this paper, whereas Hugues-Alexandre Blain (Institut 
Català de Paleoecologia Humana i Evolució Social, Tarragona) gave us permission to figure his drawings of the Iberian Chalcides dentary represented in Fig. 8a-b. Project supported by Fondi di Ateneo (2016-2017), Generalitat de Catalunya (2014 SGR 416 GRC and CERCA Program), and Spanish Ministerio de Economía y Competitividad (CGL2016-76431-P). We would also like to acknowledge the Google Books team for having digitalized some classic palaeontological books, difficult to be accessed otherwise.

\section{References}

Abbazzi, L., Angelone, C., Arca, M., Barisone, G., Bedetti, C., Delfino, M., et al. (2004). Plio-Pleistocene fossil vertebrates of Monte Tuttavista (Orosei, Eastern Sardinia, Italy), an overview. Rivista Italiana di Paleontologia e Stratigrafia, 110, 681-706.

Abdul Aziz, H., Böhme, M., Rocholl, A., Zwing, A., Prieto, L., Wijbrans, J. R., et al. (2008). Integrated stratigraphy and ${ }^{40} \mathrm{Ar} /{ }^{39} \mathrm{Ar}$ chronology of the early to middle Miocene Upper Freshwater Molasse in eastern Bavaria (Germany). International Journal of Earth Sciences, 97, 115-134.

Adams, A. L. (1866). On fossil chelonians from the ossiferous caves and fissures of Malta. Quarterly Journal of the Geological Society, 22, 594-595.

Agustí, J., Blain, H.-A., Cuenca-Bescòs, G., \& Bailon, S. (2009). Climate forcing of first hominid dispersal in Western Europe. Journal of Human Evolution, 57, 815-821.

Albert, E. M., \& Fernández, A. (2009). Evidence of cryptic speciation in a fossorial reptile: description of a new species of Blanus (Squamata: Amphisbaenia: Blanidae) from the Iberian Peninsula. Zootaxa, 2234, 56-68.

Alexejew, A. (1912). Description de la faune méotique des vertébrés des environ du village Petroviérovak (District Tiraspol). I. Anguidae. Zapiski matematicheskogo otdeleniya Novorossiiskogo obshchestva estestvoispytatelei, 39, 13-40.

Arnold, N., \& Ovenden, D. (2002). A field guide to the reptiles and amphibians of Britain and Europe. London: Harper-Collins Publisher.

Augé, M. (1993). Une nouvelle espèce de Lacertidé (Reptilia, Lacertilia) des Faluns Miocènes de l'Anjou-Touraine. Bulletin de la Société de Sciences naturelles de l'Ouest de la France, 15, 69-74.

Augé, M. (2003). La faune de Lacertilia (Reptilia, Squamata) de l'Éocène inférieur de Prémontré (Bassin de Paris, France). Geodiversitas, 25, 539-574.

Augé, M. (2005). Évolution des lézards du Paléogène en Europe. Mémoires du Muséum national d'Histoire naturelle, 192, 1-369.

Augé, M. (2012). Amphisbaenians from the European Eocene: a biogeographical review. Palaeobiodiversity and Palaeoenvironments, 92, 425-443.

Augé, M., Bailon, S., \& Malfay, J. P. (2003). Un nouveau genre de lacertidae (Reptilia, Lacertilia) dans les faluns miocènes de l'Anjou-Touraine (Maine-et-Loire, France). Geodiversitas, 25, 289-295.

Augé, M., \& Pouit, D. (2012). Presence of iguanid lizards in the European Oligocene. Lazarus taxa and fossil abundance. Bulletin de la Société Géologique de France, 183, 653-660.

Augé, M., \& Rage, J.-C. (2000). Les squamates (Reptilia) du Miocène moyen de Sansan. In L. Ginsburg (Ed.), La faune miocène de Sansan et son environnement. Mémoires du Muséum national d'Histoire naturelle, 183, 263-313.

Augé, M., \& Smith, R. (2009). An assemblage of early Oligocene lizards (Squamata) from the locality of Boutersem (Belgium), with comments on the Eocene-Oligocene transition. Zoological Journal of the Linnean Society, 155, 148-170.
Augé, M., \& Sullivan, R. M. (2006). A new genus, Paraplacosauriops (Squamata, Anguidae, Glyptosaurinae), from the Eocene of France. Journal of Vertebrate Paleontology, 26, 133-137.

Bailon, S. (1991). Amphibiens et reptiles du Pliocène et du Quaternaire de France et d'Espagne: mise en place et evolution des faunes. Paris: Université Paris VII.

Bailon, S. (2004). Fossil record of Lacertidae in Mediterranean islands: the state of the art. In V. Pérez-Mellado, N. Riera, \& A. Perera (Eds.), The biology of lacertid lizards. Evolutionary and ecological perspectives. Institut Menorquí d'Estudis, Recerca, 8, $37-62$.

Bailon, S., \& Augé, M. (2012). Un nouveau genre, Ragesaurus (Squamata, Anguidae, Anguinae), du Pléistocène inférieur des îles Medas (Catalogne, Espagne). Bulletin de la Societe Geologique de France, 183, 683-688.

Bailon, S., \& Blain, H.-A. (2007). Faunes de reptiles et changements climatiques en Europe occidentale autour de la limite PlioPléistocène. Quaternaire, 18, 55-63.

Bailon, S., Boistel, R., Bover, P., \& Alcover, J. A. (2014). Maioricalacerta rafelinensis, gen. et sp. nov., (Squamata, Lacertidae), from the early Pliocene of Mallorca (Balearic Islands, Western Mediterranean Sea). Journal of Vertebrate Paleontology, 34, 318-326.

Barahona, F., \& Barbadillo, L. J. (1997). Identification of some Iberian lacertids using skull characters. Revista Española de Herpetología, 11, 47-62.

Barbadillo, L. J., García-París, M., \& Sanchiz, B. (1997). Orígenes y relaciones evolutivas de la herpetofauna ibérica. In J. M. Pleguezuelos (Ed.), Distribución y biogeografía de los anfibios y reptiles en España y Portugal. Monografías de Herpetología, 3, 47-100.

Bell, C. J., Gauthier, J. A., \& Bever, G. S. (2010). Covert biases, circularity, and apomorphies: a critical look at the North American Quaternary Herpetofaunal Stability Hypothesis. Quaternary International, 217, 30-36.

Blain, H.-A. (2005). Contribution de la paleoherpetofaune (Amphibia \& Squamata) a la connaissance de l'evolution du climat et du paysage du Pliocene superieur au Pleistocene Moyen d'Espagne. Paris: Muséum national d'Histoire naturelle.

Blain, H.-A. (2009). Contribution de la paléoherpétofaune (Amphibia \& Squamata) à la connaissance de l'évolution du climat et du paysage du Pliocène supérieur au Pléistocène moyen d'Espagne. Treballs del Museu de Geologia de Barcelona, 16, 39-170.

Blain, H.-A. (2015). Anfibios y escamosos de Cueva Victoria. Amphibians and squamate reptiles from Cueva Victoria. Mastia, 11-12-13, 175-197.

Blain, H.-A., Agustí, J., Lordkipanidze, D., Rook, L., \& Delfino, M. (2014a). Paleoclimatic and paleoenvironmental context of the Early Pleistocene hominins from Dmanisi (Georgia, Lesser Caucasus) inferred from the herpetofaunal assemblage. Quaternary Science Reviews, 105, 136-150.

Blain, H.-A., \& Bailon, S. (2010). Anfibios y escamosos del Pleistoceno inferior de Barranco León y de Fuente Nueva 3 (Orce, Andalucía, España). In I. Toro, B. Martínez-Navarro, \& J. Agustí (Eds.), Ocupaciones humanas en el Pleistoceno inferior y medio de la Cuenca de Guadix-Baza (pp. 165-183). Sevilla: Consejería de Cultura.

Blain, H.-A., Bailon, S., \& Agustí, J. (2007). Anurans and squamate reptiles from the latest early Pleistocene of Almenara-Casablanca-3 (Castellón, East of Spain). Systematic, climatic and environmental considerations. Geodiversitas, 29, 269-295.

Blain, H.-A., Bailon, S., \& Agustí, J. (2008). Amphibians and squamate reptiles from the latest Early Pleistocene of Cueva Victoria (Murcia, southeastern Spain, SW Mediterranean): paleobiogeographic and paleoclimatic implications. Geologica Acta, 6, 345-361. 
Blain, H.-A., Bailon, S., \& Agustí, J. (2016). The geographical and chronological pattern of herpetofaunal Pleistocene extinctions on the Iberian Peninsula. Comptes Rendus Palevol, 15, 761-764.

Blain, H.-A., Bailon, S., Cuenca-Bescós, G., Arsuaga, J. L., Bermúdez De Castro, J. M., \& Carbonell, E. (2009). Long-term climate record inferred from early-middle Pleistocene amphibian and squamate reptile assemblages at the Gran Dolina Cave. Atapuerca. Spain. Journal of Human Evolution, 56, 55-65.

Blain, H.-A., Gleed-Owen, C. P., López-García, J. M., Carrión, J. S., Jennings, R., Finlayson, G., et al. (2013). Climatic conditions for the last Neanderthals: herpetofaunal record of Gorham's cave. Gibraltar. Journal of Human Evolution, 64, 289-299.

Blain, H.-A., Lozano-Fernández, I., Ollé, A., Rodríguez, J., Santonja, M., \& Pérez-González, A. (2015). The continental record of Marine Isotope Stage 11 (Middle Pleistocene) on the Iberian Peninsula characterized by herpetofaunal assemblages. Journal of Quaternary Science, 30, 667-678.

Blain, H.-A., Panera, J., Uribelarrea, D., Rubio-Jara, S., \& PérezGonzález, A. (2012). Characterization of a rapid climate shift at the MIS 8/7 transition in central Spain (Valdocarros II, Autonomous Region of Madrid) by means of the herpetological assemblages. Quaternary Science Reviews, 47, 73-81.

Blain, H.-A., Santonja, M., Pérez-González, A., Panera, J., \& RubioJara, S. (2014b). Climate and environments during Marine Isotope Stage 11 in the central Iberian Peninsula: the herpetofaunal assemblage from the Acheulean site of Áridos-1, Madrid. Quaternary Science Reviews, 94, 7-21.

Bloos, G., Böttcher, R., Heinrich, W.-D., \& Münzing, K. (1991). Ein Vorkommen von Kleinvertebraten in jung-Pleistozänen Deckschichten (Wende Eem/Würm) bei Steinheim an der Murr. Suttgarter Beiträge zur Naturkunde. Serie B (Geologie und Paläontologie), 179, 1-72.

Boettger, O. (1875). Über die Gliederung der Cyrenenmergel-Gruppe im Mainzer Becken. Bericht über die Senckenbergische Naturforschende Geselschaft, 1873-1874, 50-102.

Boettger, O. (1876/1877). Die Fauna der Corbicula-Schichten im Mainzer Becken. Palaeontographica, 24, 185-219.

Böhme, M. (1999a). Die Miozäne Fossil-Lagerstätte Sandelzhausen. 16. Fisch-und Herpetofauna - Erste Ergebnisse. Neues Jahrbuch für Geologie und Paläontologie, Abhandlungen, 214, 487-496.

Böhme, M. (1999b). Doppelschleichen (Sauria, Amphisbaenidae) aus dem Untermiozän von Stubersheim 3 (Süddeutschland). Mitteilungen der Bayerischen Staatssammlung für Paläontologie und Historische Geologie, 39, 85-90.

Böhme, M. (2002). Lower vertebrates (Teleostei, Amphibia, Sauria) from the Karpatian of the Korneuburg Basin - palaeoecological, environmental and palaeoclimatical implications. Beiträge zur Paläontologie, 27, 339-353.

Böhme, M. (2003). The Miocene Climatic Optimum: evidence from ectothermic vertebrates of Central Europe. Palaeogeography, Palaeoclimatology, Palaeoecology, 195, 389-401.

Böhme, M. (2010). Ectothermic vertebrates (Actinopterygii, Allocaudata, Urodela, Anura, Crocodylia, Squamata) from the Miocene of Sandelzhausen (Germany, Bavaria) and their implications for environment reconstruction and palaeoclimate. Paläontologische Zeitschrift, 84, 3-41.

Böhme, M., \& Ilg, A. (2003). fosFARbase www.wahre-staerke.com/ Accessed in 2017.

Böhme, M., \& Vasilyan, D. (2014). Ectotermic vertebrates from the late middle Miocene of Gratkorn (Austria, Styria). Palaeobiodiversity and Palaeoenvironments, 94, 21-40.

Böhme, W., \& Zammit-Maempel, G. (1982). Lacerta siculimelitensis sp. n. (Sauria: Lacertidae), a giant lizard from the Late Pleistocene of Malta. Amphibia-Reptilia, 3, 257-268.

Bolet, A. (2017). First early Eocene lizards from Spain and a study of the compositional changes between late Mesozoic and early
Cenozoic Iberian lizard assemblages. Palaeontologia Electronica, 20.2.20A, 1-22.

Bolet, A., Daza, J. D., Augé, M., \& Bauer, A. M. (2015). New genus and species names for the Eocene lizard Cadurcogekko rugosus Augé, 2005. Zootaxa, 3985, 265-274.

Bolet, A., Delfino, M., Fortuny, J., Almécija, S., Robles, J. M., \& Alba, D. M. (2014). An amphisbaenian skull from the European Miocene and the evolution of Mediterranean worm Lizards. PLOS ONE, 9, e98082.

Bolet, A., \& Evans, S. E. (2013a). Fossil history of chamaeleons. In K. A. Tolley \& A. Herrel (Eds.), The biology of chamaeleons (pp. 175-192). Berkeley: University of California Press.

Bolet, A., \& Evans, S. E. (2013b). Lizards and amphisbaenians (Reptilia, Squamata) from the late Eocene of Sossís (Catalonia, Spain). Palaeontologia Electronica, 16.1.8A, 1-23.

Bolkay, S. J. (1913). Additions to the fossil herpetology of Hungary from the Pannonian and Praeglacial periode. Jahrbuche der Ungarischen geologischen Reichsanstalt, 21, 217-230.

Bonfiglio, L., \& Insacco, G. (1992). Palaeoenvironmental, paleontologic and stratigraphic significance of vertebrate remains in Pleistocene limnic and alluvial deposits from Southeastern Sicily. Palaeogeography, Palaeoclimatology, Palaeoecology, 95, 195-208.

Bonfiglio, L., Marra, A. C., Masini, F., Pavia, M., \& Petruso, D. (2002). Pleistocene faunas of Sicily: a review. In W. H. Waldren, \& J. A. Ensenyat (Eds.), World islands in prehistory: international insular investigations. British Archaeological Reports, International Series, 1095, 428-436.

Brunner, G. (1954). Das Fuchsloch bei Siegmannsbrunn (Oberfr.) (Eine mediterrane Riss-Wiirm-Fauna). Neues Jahrbuch für Geologie und Palaontologie, 100, 83-118.

Caldwell, M. W., Nydam, R. L., Palci, A., \& Apesteguía, S. (2015). The oldest known snakes from the Middle Jurassic-Lower Cretaceous provide insights on snake evolution. Nature Communications, 6, 5996.

Caloi, L., Kotsakis, T., \& Palombo, M. R. (1986). La fauna a vertebrati terrestri del Pleistocene delle isole del Mediterraneo. Geologica Romana, 25, 235-256.

Carranza, S., \& Arnold, E. N. (2006). Systematics, biogeography, and evolution of Hemidactylus geckos (Reptilia: Gekkonidae) elucidated using mitochondrial DNA sequences. Molecular Phylogenetics and Evolution, 38, 531-545.

Ceríaco, L. M. P., \& Bauer, A. M. (2018). An integrative approach to the nomenclature and taxonomic status of the genus Blanus Wagler, 1830 (Squamata: Blanidae) from the Iberian Peninsula. Journal of Natural History, 52, 849-880.

Čerňanský, A. (2010a). A revision of chamaeleonids from the lower Miocene of the Czech Republic with description of a new species of Chamaeleo (Squamata, Chamaeleonidae). Geobios, 43, 605-613.

Čerňanský, A. (2010b). Earliest world record of green lizards (Lacertilia, Lacertidae) from the Lower Miocene of Central Europe. Biologia, 65, 737-741.

Čerňanský, A. (2011). A revision of the chameleon species Chamaeleo pfeili Schleich (Squamata; Chamaeleonidae) with description of a new material of chamaeleonids from the Miocene deposits of southern Germany. Bulletin of Geosciences, 86, 275-282.

Čerňanský, A. (2012). The oldest known European Neogene girdled lizard fauna (Squamata, Cordylidae), with comments on early Miocene immigration of African taxa. Geodiversitas, 34, 837-848.

Čerňanský, A. (2016). Another piece of the puzzle: the first report on the Early Miocene lizard fauna from Austria (Ottnangian, MN 4; Oberdorf locality). Paläontologische Zeitschrift, 90, 723-746. 
Čerňanský, A., \& Bauer, A. M. (2010). Euleptes gallica Müller (Squamata: Gekkota: Sphaerodactylidae) from the Lower Miocene of North-West Bohemia, Czech Republic. Folia Zoologica, 59, 323-328.

Čerňanský, A., Bolet, A., Müller, J., Rage, J.-C., Augé, M., \& Herrel, A. (2017a). A new exceptionally preserved specimen of Dracaenosaurus (Squamata, Lacertidae) from the Oligocene of France as revealed by micro-computed tomography. Journal of Vertebrate Paleontology, 37, e1384738.

Čerňanský, A., Daza, J. D., \& Bauer, A. M. (2018). Geckos from the middle Miocene of Devínska Nová Ves (Slovakia): new material and a review of the previous record. Swiss Journal of Geosciences, 111, 183-190.

Čerňanský, A., Klembara, J., \& Müller, J. (2016a). The new rare record of the late Oligocene lizards and amphisbaenians from Germany and its impact on our knowledge of the European terminal Palaeogene. Palaeobiodiversity and Palaeoenvironments, 96, 559-587.

Čerňanský, A., Klembara, J., \& Smith, K. T. (2016b). Fossil lizard from central Europe resolves the origin of large body size and herbivory in giant Canary Island lacertids. Zoological Journal of the Linnean Society, 176, 861-877.

Čerňanský, A., Rage, J.-C., \& Klembara, J. (2015). The Early Miocene squamates of Amöneburg (Germany): the first stages of modern squamates in Europe. Journal of Systematic Palaeontology, 13, 97-128.

Čerňanský, A., \& Smith, K. T. (2018). Eolacertidae: a new extinct clade of lizards from the Palaeogene; with comments on the origin of the dominant European reptile group - Lacertidae. Historical Biology, 30, 994-1014.

Čerňanský, A., Szyndlar, Z., \& Mörs, T. (2017b). Fossil squamate faunas from the Neogene of Hambach (northwestern Germany). Palaeobiodiversity and Palaeoenvironments, 97, 329-354.

Čerňanský, A., \& Venczel, M. (2011). An amphisbaenid reptile (Squamata, Amphisbaenidae) from the lower Miocene of Northwest Bohemia (MN 3, Czech Republic). Neues Jahrbuch für Geologie und Paläontologie-Abhandlungen, 260, 73-77.

Cirilli, O., Benvenuti, M. G., Carnevale, G., Casanovas Vilar, I., Delfino, M., Furió, M., et al. (2016). Fosso della Fittaia: the oldest Tusco-Sardinian late Miocene endemic vertebrate assemblages (Baccinello-Cinigiano Basin, Tuscany, Italy). Rivista Italiana di Paleontologia e Stratigrafia, 122, 13-34.

Colombero, S., Alba, D. M., D'amico, C., Delfino, M., Esu, D., Giuntelli, P., et al. (2017). Late Messinian mollusks and vertebrates from Moncucco Torinese, North-Western Italy. Paleoecological and paleoclimatological implications. Palaeontologia Electronica, 20.1.10A, 1-66.

Colombero, S., Angelone, C., Bonelli, E., Carnevale, G., Cavallo, O., Delfino, M., et al. (2014). The upper Messinian assemblages of fossil vertebrate remains of Verduno (NW Italy): another brick for a latest Miocene bridge across the Mediterranean. Neues Jahrbuch für Geologie und Paläontologie-Abhandlungen, 272, 287-324.

Conrad, J. L. (2008). Phylogeny and systematics of Squamata (Reptilia) based on morphology. Bulletin of the American Museum of Natural History, 310, 1-182.

Conrad, J. L., Ast, J. C., Montanari, S., \& Norell, M. A. (2010). A combined evidence phylogenetic analysis of Anguimorpha (Reptilia: Squamata). Cladistics, 16, 1-48.

Conrad, J. L., Balcarcel, A., \& Mehling, C. (2012). Earliest example of a giant monitor lizard (Varanus, Varanidae, Squamata). PLoS ONE, 7, e41767.

Crespo, E. G. (2001). Paleo-herpetofauna de Portugal. Lisbon: Museu Bocage.

Daza, J. D., Bauer, A. M., \& Snively, E. D. (2014). On the fossil record of the Gekkota. The Anatomical Record, 97, 433-462.
De Gregorio, A. (1925). Mammiferi quaternari di Sicilia (Microfauna). Mammiferi e altri vertebrati (Myoxus, Lepus, Lagomys, Pellegrinia, Mustela, Crocidura, Lacerta e Testudo etc.). Annales de Geologie et Paléontologie, 43, 1-19.

de Rochebrune, A. (1884). Faune ophiologique des Phosphorites du Quercy. Mémoires de la Société des sciences naturelles de Saône-et-Loire, 5, 149-164.

Delfino, M. (1997a). Italian paleoerpetofauna database: NeogeneQuaternary. In Z. Roček, \& S. Hart (Eds.), Herpetology '97. Abstract of the III World Congress of Herpetology, 2-10 August 1997, Prague, Czech Republic (51-52.). Prague: Third World Congress of Herpetology.

Delfino, M. (1997b). Blanus from the Early Pleistocene of Southern Italy: another small tessera from a big mosaic. In W. Böhme, W. Bischoff, \& T. Ziegler (Eds.), Herpetologia Bonnensis (89-97.). Bonn: Societas Europaea Herpetologica.

Delfino, M. (2002). Erpetofaune Italiane del Neogene e del Quaternario. Modena: University of Modena and Reggio Emilia.

Delfino, M. (2003). A Pleistocene amphisbaenian from Sicily. Amphibia-Reptilia, 24, 407-414.

Delfino, M. (2004). The Middle Pleistocene herpetofauna of Valdemino Cave (Liguria, North-Western Italy). Herpetological Journal, 14, 113-128.

Delfino, M. (2006). Il registro fossile della moderna erpetofauna italiana. In R. Sindaco, G. Doria, E. Razzetti, \& F. Bernini (Eds.), Atlante degli anfibi e dei rettili d'Italia/Atlas of Italian amphibians and reptiles (pp. 96-119). Firenze: Societas Herpetologica Italica, Edizioni Polistampa.

Delfino, M. (2013). Cenozoic herpetofaunas of Apulia (Southern Italy). In G. Scillitani, C. Liuzzi, L. Lorusso, F. Mastropasqua, \& P. Ventrella (Eds.), Atti IX Congresso Nazionale della Societas Herpetologica Italica (Bari - Conversano, 26-30 settembre 2012) (pp. 99-103). Conversano: Tipolitografia Pineta.

Delfino, M., \& Bailon, S. (2000). Early Pleistocene herpetofauna from Cava Dell'Erba and Cava Pirro (Apulia, Southern Italy). Herpetological Journal, 10, 95-110.

Delfino, M., Bailon, S., \& Pitruzzella, G. (2011). The late Pliocene amphibians and reptiles from "Capo Mannu D1 Local Fauna" (Mandriola, Sardinia, Italy). Geodiversitas, 33, 357-382.

Delfino, M., Kotsakis, T., Arca, M., Tuveri, C., Pitruzzella, G., \& Rook, L. (2008). Agamid lizards from the Plio-Pleistocene of Sardinia (Italy) and an overview of the European fossil record of the family. Geodiversitas, 30, 641-656.

Delfino, M., Rage, J.-C., Bolet, A., \& Alba, D. M. (2013). Early Miocene dispersal of the lizard Varanus into Europe: reassessment of vertebral material from Spain. Acta Palaeontologica Polonica, 58, 731-735.

Delfino, M., \& Rook, L. (2008). The fossil amphibians and reptiles of Sardinia: a summary. In C. Corti (Ed.), Herpetologia Sardiniae (pp. 192-195). Latina: Societas Herpetologica Italica/Edizioni Belvedere.

Depéret, C. (1890). Les animaux pliocènes du Roussillon. Mémoires de la Société géologique de France, Paléontologie, 3, 1-194.

Estes, R. (1969). Die Fauna der Miozänen Spaltenfüllung von Neudorf an der March (CSSR). Reptilia (Lacertilia). Sitzungsberichte der Akademie der Wissenschaften mathematisch-naturwissenschaftliche Klasse, 178, 77-82.

Estes, R. (1983). Handbuch der Paläoherpetologie 10A. Sauria terrestria, Amphisbaenia. Munich: Friedrich Pfeil.

Evans, E. S. (1991). A new lizard-like reptile (Diapsida: Lepidosauromorpha) from the Middle Jurassic of England. Zoological Journal of the Linnean Society, 103, 391-412.

Evans, S. E. (1994). A new anguimorph lizard from the Jurassic and lower Cretaceous of England. Palaeontology, 37, 33-49. 
Evans, S. E. (1998). Crown group lizards (Reptilia, Squamata) from the Middle Jurassic of the British Isles. Palaeontographica, Abteilung A, 250, 123-154.

Evans, S. E. (2008). The skull of lizards and Tuatara. In C. Gans, A. Gaunt., \& K. Adler (Eds.), Biology of the Reptilia, vol. 20 (The skull of Lepidosauria). Contributions to Herpetology, 23, 1-347.

Evans, S. E., Barrett, P. M., Hilton, J., Butler, R., Jones, M. E. H., Liang, M. M., et al. (2006). The Middle Jurassic vertebrate assemblage of Skye, Scotland. In S. E. Evans, \& P. M. Barrett (Eds.), Ninth Symposium on Mesozoic Terrestrial Ecosystems and Biota (36-39.). London: Natural History Museum Publications.

Evans, S. E., \& Milner, A. R. (1994). Middle Jurassic microvertebrate assemblages from the British Isles. In N. C. Fraser \& E. D. Sues (Eds.), In the shadow of the dinosaurs: Early Mesozoic tetrapods (pp. 303-321). Cambridge: Cambridge University Press.

Evans, S. E., Prasad, G. V. R., \& Manhas, B. K. (2002). Fossil lizards from the Jurassic Kota Formation of India. Journal of Vertebrate Paleontology, 22, 299-312.

Ferrandini, J., Salotti, M., Bailon, S., Bonifay, M. F., MourerChauviré, C., \& Real-Testud, A. M. (1995). Découverte d'importants remplissages fossilifères d'âge pléistocène supérieur et holocène dans le karst de la région d'Oletta (Haute Corse). Geobios, 28, 117-124.

Folie, A., Smith, R., \& Smith, T. (2013). New amphisbaenian lizards from the Early Paleogene of Europe and their implications for the early evolution of modern amphisbaenians. Geologica Belgica, 16, 227-235.

Fraser, N. C. (1982). A new rhynchocephalian from the British Upper Trias. Palaeontology, 25, 709-725.

Fraser, N. C., \& Benton, M. J. (1989). The Triassic reptiles Brachyrhinodon and Polysphenodon and the relationships of the sphenodontids. Zoological Journal of the Linnean Society, 96, 413-445.

Gamble, T., Greenbaum, E., Jackman, T. R., Russell, A. P., \& Bauer, A. M. (2012). Repeated origin and loss of adhesive toepads in geckos. PLoS One, 7, e39429.

Gamble, T., Greenbaum, E., Jackman, T. R., Russell, A. P., \& Bauer, A. M. (2015). Into the light: diurnality has evolved multiple times in geckos. Biological Journal of the Linnean Society, 115, 896-910.

García-Porta, J., Quintana, J., \& Bailon, S. (2002). Primer hallazgo de Blanus sp. (Amphisbaenia, Reptilia) en el Neógeno balear. Revista Española de Herpetología, 16, 19-28.

Gaudry, A. (1862). Animaux fossiles et géologie de l'Attique d'après les recherchers faites en 1855-56 et an 1860. Paris: F. Savy Editeur.

Gauthier, J., Kearney, M., Maisano, J. A., Rieppel, O., \& Behlke, A. D. B. (2012). Assembling the squamate tree of life: perspectives from the phenotype and the fossil record. Bulletin of the Peabody Museum of Natural History, 53, 3-308.

Georgalis, G. L. (2017). Necrosaurus or Palaeovaranus? Appropriate nomenclature and taxonomic content of an enigmatic fossil lizard clade (Squamata). Annales de Paléontologie, 103, 293-303.

Georgalis, G. L., Villa, A., \& Delfino, M. (2016a). First description of a fossil chamaeleonid from Greece and its relevance for the European biogeographic history of the group. The Science of Nature, 103, 1-12.

Georgalis, G. L., Villa, A., \& Delfino, M. (2017a). Fossil lizards and snakes from Ano Metochi-a diverse squamate fauna from the latest Miocene of northern Greece. Historical Biology, 29, 730-742.

Georgalis, G. L., Villa, A., \& Delfino, M. (2017b). The last European varanid: demise and extinction of monitor lizards (Squamata,
Varanidae) from Europe. Journal of Vertebrate Paleontology, 37, e1301946.

Georgalis, G. L., Villa, A., \& Delfino, M. (2018). The last amphisbaenian (Squamata) from continental Eastern Europe. Annales de Paléontologie, 104, 155-159.

Georgalis, G. L., Villa, A., Vlachos, E., \& Delfino, M. (2016b). Fossil amphibians and reptiles from Plakias, Crete: a glimpse into the earliest late Miocene herpetofaunas of southeastern Europe. Geobios, 49, 433-444.

Gerhardt, K. (1903). Ophisaurus ulmensis n. sp. aus dem Untermiozän von Ulm a. D. Jahreshefte des Vereins für Vaterländische Naturkunde in Württemberg, 59, 67-71.

Gervais, P. (1859). Zoologie et Paléontologie Françaises. Paris: Arthus Bertrand.

Gulia, G. (1912). La geologia ed i fossili delle Isole Maltesi. In G. Muscat (Ed.), General Guide to Malta and Gozo for the year 1912 (pp. 291-318). Valletta: The Malta Herald.

Gulia, G. (1914). Uno sguardo alla zoologia delle "Isole Maltesi". In L. Jourin (Ed.), IX congrès international de zoologie tenu á Monaco du 25 au 30 mars 1913 (pp. 545-555). Imprimerie Oberthür: Rennes.

Gvoždík, V., Benkovský, N., Crottini, A., Bellati, A., Moravec, J., Romano, A., et al. (2013). An ancient lineage of slow worms, genus Anguis (Squamata: Anguidae), survived in the Italian Peninsula. Molecular Phylogenetics and Evolution, 69, 1077-1092.

Gvoždík, V., Jandzik, D., Lymberakis, P., Jablonski, D., \& Moravec, J. (2010). Slow worm, Anguis fragilis (Reptilia: Anguidae) as a species complex: Genetic structure reveals deep divergences. Molecular Phylogenetics and Evolution, 55, 460-472.

Harris, D. J., Batista, V., Carretero, M. A., \& Ferrand, N. (2004). Genetic variation in Tarentola mauritanica (Reptilia: Gekkonidae) across the Strait of Gibraltar derived from mitochondrial and nuclear DNA sequences. Amphibia-Reptilia, 25, 451-459.

Hedges, S. B., \& Vidal, N. (2009). Lizards, snakes, and amphisbaenians (Squamata). In S. B. Hedges \& S. Kumar (Eds.), The timetree of life (pp. 383-389). New York: Oxford University Press.

Hoffstetter, R. (1942). Sur la présence d'Amphisbaenidae dans les gisements tertiaires français. Comptes rendues des Séances de la Societé de Géologie de France, 3-4, 24-25.

Hoffstetter, R. (1943). Varanidae et Necrosauridae fossiles. Bulletin du Muséum National d'Histoire Naturelle, 15, 134-141.

Hoffstetter, R. (1944). Sur les Scincidae fossiles. I. Formes européennes et nord-américaines. Bulletin du Muséum National d'Histoire Naturelle, Paris, 16, 547-553.

Hoffstetter, R. (1946). Sur les Gekkonidae fossiles. Bulletin du Muséum National d'Histoire Naturelle, 18, 195-203.

Hoffstetter, R. (1969). Présence de Varanidae (Reptilia, Sauria) dans le Miocène de Catalogne. Considérations sur l'histoire de la famille. Bulletin du Muséum National d'Histoire Naturelle, 40, 1051-1064.

Holman, J. A. (1998). Pleistocene amphibians and reptiles in Britain and Europe. Oxford monographs on geology and geophysics, 38, $1-254$.

Holmes, R. B., Murray, A. M., Attia, Y. S., Simons, E. L., \& Chatrath, P. (2010). Oldest known Varanus (Squamata: Varanidae) from the upper Eocene and lower Oligocene of Egypt: support for an African origin of the genus. Palaeontology, 53, 1099-1110.

Ivanov, M., Ruta, M., Klembara, J., \& Böhme, M. (2018). A new species of Varanus (Anguimorpha: Varanidae) from the early Miocene of the Czech Republic, and its relationships and palaeoecology. Journal of Systematic Palaeontology, 16, 767-797.

Jánossy, D. (1986). Pleistocene vertebrate faunas of Hungary. Budapest: Elsevier/Akadémiai Kiadó. 
Jones, M. E. H., Anderson, C. L., Hipsley, C. A., Müller, J., Evans, S. E., \& Schoch, R. R. (2013). Integration of molecules and new fossils supports a Triassic origin for Lepidosauria (lizards, snakes, and tuatara). BMC Evolutionary Biology, 13, 208.

Jörg, E. (1965). Ophisaurus acuminatus nov. spec. (Anguidae, Rept.) von der pontischen Wirbeltier-Fundstätte Höwenegg Hegau. Beiträge zur naturkundlichen Forschungen in SW-Deutschland, 24, 21-30.

Jost, J., Kälin, D., Börner, S., Vasilyan, D., Lawver, D., \& Reichenbacher, B. (2015). Vertebrate microfossils from the Upper Freshwater Molasse in the Swiss Molasse Basin: implications for the evolution of the North Alpine Foreland Basin during the Miocene Climate Optimum. Palaeogeography, Palaeoclimatology, Palaeoecology, 426, 22-33.

Jovanović, M., Đurić, D., \& Marković, Z. (2002). Tertiary reptiles of the central part of the Balkan peninsula. Biota, 3, 67-75.

Karin, B. R., Metallinou, M., Weinell, J. L., Jackman, T. R., \& Bauer, A. M. (2016). Resolving the higher-order phylogenetic relationships of the circumtropical Mabuya group (Squamata: Scincidae): an out-of-Asia diversification. Molecular Phylogenetics and Evolution, 102, 220-232.

Kearney, M. (2003). Systematics of the Amphisbaenia (Lepidosauria: Squamata) based on morphological evidence from recent and fossil forms. Herpetological Monographs, 17, 1-74.

Klembara, J. (1979). Neue funde der gattungen Ophisaurus und Anguis (Squamata, Reptilia) aus dem Untermiozän Westböhmens (ČSSR). Vestník Ústredního Ústavu Geologického, 54, 163-170.

Klembara, J. (1986). Neue funde der gattungen Pseudopus und Anguis (Reptilia, Anguinae) aus dei Pliopleistozänen Mitteleuropäischen lokalitäten. Geologica Carpathica, 37, 91-106.

Klembara, J. (2008). A new anguimorph lizard from the lower Miocene of North-West Bohemia, Czech Republic. Palaeontology, 51, 81-94.

Klembara, J. (2015). New finds of anguines (Squamata, Anguidae) from the early Miocene of Northwest Bohemia (Czech Republic). Paläontologische Zeitschrift, 89, 171-195.

Klembara, J., Böhme, M., \& Rummel, M. (2010). Revision of the anguine lizard Pseudopus laurillardi (Squamata, Anguidae) from the Miocene of Europe, with comments on paleoecology. Journal of Paleontology, 84, 159-196.

Klembara, J., \& Green, B. (2010). Anguimorph lizards (Squamata, Anguimorpha) from the middle and late Eocene of the Hampshire Basin of southern England. Journal of Systematic Palaeontology, 8, 97-129.

Klembara, J., Hain, M., \& Čerňanský, A. (2017). The first record of anguine lizards (Anguimorpha, Anguidae) from the early Miocene locality Ulm-Westtangente in Germany. Historical Biology, https://doi.org/10.1080/08912963.2017.1416469

Klembara, J., Hain, M., \& Dobiašová, K. (2014). Comparative anatomy of the lower jaw and dentition of Pseudopus apodus and the interrelationships of species of subfamily Anguinae (Anguimorpha, Anguidae). The Anatomical Record, 297, 516-544.

Klembara, J., \& Rummel, M. (2018). New material of Ophisaurus, Anguis and Pseudopus (Squamata, Anguidae, Anguinae) from the Miocene of the Czech Republic and Germany and systematic revision and palaeobiogeography of the Cenozoic Anguinae. Geological Magazine, 155, 20-44.

Kosma, R. (2004). The dentitions of recent and fossil scincomorphan lizards (Lacertilia, Squamata)—systematics, functional morphology, palecology. Hannover: Universität Hannover.

Kotsakis, T. (1977). I resti di anfibi e rettili pleistocenici della grotta di Spinagallo (Siracusa, Sicilia). Geologica Romana, 16, 211-229.
Kretzoi, M., \& Poulianos, N. (1981). Remarks on the middle and lower Pleistocene vertebrate fauna in the Petralona Cave. Anthropos, 8, 57-72.

Lartet, E. (1851). Notice sur la colline de Sansan. Auch: J.-A. Portes.

Lungu, A. N., Zerova, G. A., \& Chkhikvadze, V. M. (1983). Pervie svedeniia o miotsenovom varane severnogo prichernomoriia. Soobshcheniya Akademii Nauk Gruziinskoi SSR, 110, 417-420.

Mangili, G. (1980). Fossils reptiles of Simonelli cave. Quaderni della Accademia Nazionale dei Lincei, 249, 121-122.

Mateo, J. A. (1988). Estudio sistemático y zoogeográfico de los lagartos ocelados, Lacerta lepida Daudin, 1802, y Lacerta pater (Lataste, 1880) (Sauria: Lacertidae). Sevilla: University of Sevilla.

Meszoely, C. A. M., \& Gasparik, M. (2002). First record of an agamid lizard from the Pleistocene of Hungary. Fragmenta Palaeontologica Hungarica, 20, 1-2.

Meszoely, C. A. M., Schaff, C. R., \& Jenkins, F., Jr. (1987). Early Jurassic sphenodontians from northeast Arizona. Journal of Vertebrate Paleontology, 7, 21A.

Miklas-Tempfer, P. M. (2003). The Miocene herpetofaunas of Grund (Caudata; Chelonii, Sauria, Serpentes) and Mülbach am Manhartsberg (Chelonii, Sauria, Amphisbaenia, Serpentes), Lower Austria. Annalen des Naturhistorischen Museums in Wien, 104A, 195-235.

Młynarski, M. (1956). Lizards from the Pliocene of Poland. Acta Palaeontologica Polonica, 1, 135-152.

Młynarski, M. (1962). Notes on the amphibian and reptilian fauna of the Polish Pliocene and Early Pleistocene. Acta Zoologica Cracoviensia, 7, 177-194.

Montoya, P., Alberdi, M. T., Barbadillo, L. J., Van Der Made, J., Morales, J., Murelaga, X., et al. (2001). Une faune très diversifiée du Pléistocène inférieur de la Sierra de Quibas (province de Murcia, Espagne). Comptes Rendus de l'Académie des Sciences, Earth and Planetary Science, 332, 387-393.

Moody, S., \& Roček, Z. (1980). Chamaeleo caroliquarti (Chamaeleonidae, Sauria) a new species from the lower Miocene of central Europe. Věstnik Ústředniho Ustavu Geologického, 55, $85-92$.

Morelli, N. (1891). Resti organici rinvenuti nella caverna delle Arene Candide. Atti della Società Ligustica di Scienze Naturali e Geografiche, 2, 171-205.

Mukhopadhyay, G., Mukhopadhyay, S. K., Roychowdhury, M., \& Parui, P. K. (2010). Stratigraphic correlation between different Gondwana basins of India. Journal of the Geological Society of India, 76, 251-266.

Müller, J. (1996). Eine neue Art der echten Eidechsen (Reptilia: Lacertilia: Lacertidae) aus dem Unteren Miozän von Poncenat, Frankreich. Mainzer Geowissenschaftliche Mitteilungen, 25, $79-88$.

Müller, J. (2001). A new fossil species of Euleptes from the early Miocene of Montaigu, France (Reptilia, Gekkonidae). AmphibiaReptilia, 22, 341-348.

Müller, J., \& Mödden, C. (2001). A fossil leaf-toed gecko from the Oppenheim-Nierstein Quarry (Lower Miocene, Germany). Journal of Herpetology, 35, 529-532.

Nopcsa, F. (1908). Zur Kenntnis der fossilen Eidechsen. Beiträge zur Paläontologie von Österreich, 21, 33-62.

Papp, A., Thenius, E., Berger, W., \& Weinfurter, E. (1953). Vösendorf - ein Lebensbild aus dem Pannon des Wiener Beckens. Ein beitrag zur geologie und paläontologie der unterpliozänen congerienschichten des südlichen Wiener Beckens. Mitteilungen der Geologischen Gesellschaft in Wien, 46, $1-109$.

Pomel, M. (1853). Catalogue méthodique et descriptif des vertébrés fossiles découverts dans le bassin hydrogeographique supérieur 
de la Loire, et surtout dans la vallée de son affluent principal, ĺAllier. Paris: J.-B. Baillière.

Prasad, G. V. R., \& Manhas, B. K. (2007). A new docodont mammal from the Jurassic Kota Formation of India. Palaeontologia Electronica, 10, 7A

Pyron, R. A., Burbrink, F. T., \& Wiens, J. J. (2013). A phylogeny and revised classification of Squamata, including 4161 species of lizards and snakes. BMC Evolutionary Biology, 13, 93.

Rage, J.-C. (2013). Mesozoic and Cenozoic squamates of Europe. Palaeobiodiversity and Palaeoenvironments, 93, 517-534.

Rage, J.-C., \& Bailon, S. (2005). Amphibians and squamate reptiles from the late early Miocene (MN 4) of Béon 1 (Montréal-duGers, southwestern France). Geodiversitas, 27, 413-441.

Rage, J.-C., \& Szyndlar, Z. (2005). Latest Oligocene-early Miocene in Europe: dark Period for booid snakes. Comptes Rendus Palevol, 4, 428-435.

Rato, C., Carranza, S., \& Harris, D. J. (2011). When selection deceives phylogeographic interpretation: the case of the Mediterranean house gecko, Hemidactylus turcicus (Linnaeus, 1758). Molecular Phylogenetics and Evolution, 58, 365-373.

Rato, C., Carranza, S., Perera, A., Carretero, M. A., \& Harris, D. J. (2010). Conflicting patterns of nucleotide diversity between mtDNA and nDNA in the Moorish gecko, Tarentola mauritanica. Molecular Phylogenetics and Evolution, 56, 962-971.

Rauscher, K. L. (1992). Die Echsen (Lacertilia, Reptilia) aus dem Plio-Pleistozän von Bad Deutsch-Altenburg, Niederösterreich. Beiträge zur paläontologie von Österreich, 17, 81-177.

Rauscher, K. L. (1995). Die herpetofauna der Vraona-Hölhe (Attika) in Griechenland. Annales Géologiques des Pays Helléniques, 36, 39-41.

Renesto, S., \& Posenato, R. (2003). A new lepidosauromorph reptile from the Middle Triassic of the Dolomites (Northern Italy). Rivista Italiana di Paleontologia e Stratigrafia, 109, 463-474.

Reynoso, V. H. (1998). Huehuecuetzpali mixtecus gen. et sp. nov: a basal squamate (Reptilia) from the Early Cretaceous of Tepexi de Rodríguez, Central México. Philosophical Transactions of the Royal Society of London B, Biological Sciences, 353, 477-500.

Roček, Z. (1984). Lizards (Reptilia: Sauria) from the lower Miocene locality Dolnice (Bohemia, Czechoslovakia). Rozpravy Československé Akademie Věd - ̌̌ada Matematických a Př́rodních Věd, 94, 3-64.

Roger, O. (1898). Wirbelthierreste aus dem Dinotheriensande, II. Theil. Bericht des Naturwissenschaftlichen Vereins fur Schwaben und Neuburg (a.V.) in Augsburg, 33, 385-396.

Rook, L., Abbazzi, L., Angelone, C., Arca, M., Barisone, G., Bedetti, C., et al. (2003). Osservazioni preliminari sui vertebrati fossili plio-pleistocenici del Monte Tuttavista (Orosei, Sardegna). International Journal of Archaeology-Sardinia Corsica et Baleares Antiquae, 1, 11-29.

Salotti, M., Bailon, S., Bonifay, M.-F., Courtois, J.-Y., Dubois, J.-N., Ferrandini, J., et al. (1997). Castiglione 3, un nouveau remplissage fossilifère d'âge Pléistocène moyen dans le karst de la région d'Oletta (Haute-Corse). Comptes Rendus de l'Académie des Sciences, Paris, IIa, 324, 67-74.

Salotti, M., Louchart, A., Bailon, S., Lorenzo, S., Oberlin, C., et al. (2008). A Teppa di U Lupinu Cave (Corsica, France)—-human presence since 8500 years $\mathrm{BC}$, and the enigmatic origin of the earlier, late Pleistocene accumulation. Acta Zoologica Cracoviensia, 51A, 15-34.

Sampaio, F. L., Harris, D. J., Perera, A., \& Salvi, D. (2015). Phylogenetic and diversity patterns of Blanus worm lizards (Squamata: Amphisbaenia): insights from mitochondrial and nuclear gene genealogies and species tree. Journal of Zoological Systematics and Evolutionary Research, 53, 45-54.

Savona Ventura, C. (1984). The fossil herpetofauna of the Maltese islands, a review. Naturalista Siciliano, 8, 93-106.
Schleich, H. H. (1983). Die mittelmiozäne Fossil-Lagerstätte Sandelzhausen. 13. Chamaeleo bavaricus sp. nov., ein neuer Nachweis aus dem Jungtertiär Süddeutschlands. Mitteilungen der Bayerischen Staatssammlung für Paläontologie und Historische Geologie, 23, 77-82.

Schleich, H. H. (1984). Neue Reptilienfunde aus dem Tertiär Deutschlands. 2. Chamaeleo pfeili sp. nov. von der untermiozänen Fossilfundstelle Rauscheröd/Niederbayern (Reptilia, Sauria, Chamaeleonidae). Mitteilungen der Bayerischen Staatssammlung für Paläontologie und Historische Geologie, 24, 97-104.

Schleich, H. H. (1985). Neue reptilienfunde aus dem Tertiär Deutschlands. 3. Erstnachweis von Doppelschleichen (Blanus antiquus sp.nov.) aus dem Mittelmiozän Süddeutschlands. Münchner Geowissenschaftliche Abhandlungen Reihe A, 4, $1-16$.

Schleich, H. H. (1987). Neue reptilienfunde aus dem Tertiär Deutschlands. 7. Erstnachweis von Geckos aus dem Mittelmiozän Süddeutschlands: Palaeogekko risgoviensis nov. gen., nov. spec. (Reptilia, Sauria, Gekkonidae). Mitteilungen der Bayerischen Staatssammlung für Palaeontologie und Historische Geologie, 27, 67-93.

Schleich, H. H. (1988). Neue reptilienfunde aus dem Tertiär Deutschlands 8. Palaeoblanus tobieni n.gen., n.sp.-Neue Doppelschleichen aus dem Tertiär Deutschlands. Paläontologische Zeitschrift, 62, 95-105.

Schleich, H. H. (1994). Neue Reptilienfunde aus dem Tertiär Deutschlands 15. Neue Funde fossiler Chamäleonen aus dem Neogen Süddeutschlands. Courier Forschungsinstitut Senckenberg, 173, 175-195.

Schmitz, A., Mausfeld, P., \& Embert, D. (2004). Molecular studies on the genus Eumeces Wiegmann, 1834: phylogenetic relationships and taxonomic implications. Hamadryad, 28, 73-89.

Sears, M. W., \& Angilletta, M. J., Jr. (2004). Body size clines in Sceloporus lizards: proximate mechanisms and demographic constraints. Integrative and Comparative Biology, 44, 433-442.

Sickenberg, O. (1971). Revision der wirbeltierfauna der Höhle Petralona (Griech, Mazedonien). Annales Géologiques des Pays Helléniques, 23, 230-264.

Sillero, N., Campos, J., Bonardi, A., Corti, C., Creemers, R., Crochet, P.-A., et al. (2014). Updated distribution and biogeography of amphibians and reptiles of Europe. Amphibia-Reptilia, 35, 1-31.

Simões, T. R., Caldwell, M. W., Tałanda, M., Bernardi, M., Palci, A., Vernygora, O., et al. (2018). The origin of squamates revealed by a Middle Triassic lizard from the Italian Alps. Nature, 557, 706-709.

Sindaco, R., Kornilios, P., Sacchi, R., \& Lymberakis, P. (2014). Taxonomic reassessment of Blanus strauchi (Bedriaga, 1884) (Squamata: Amphisbaenia: Blanidae), with the description of a new species from South-East Anatolia (Turkey). Zootaxa, 3795, 311-326.

Smith, K. T. (2017). First crocodile-tailed lizard (Squamata: PanShinisaurus) from the Paleogene of Europe. Journal of Vertebrate Paleontology, 37, e1313743.

Smith, K. T., \& Gauthier, J. A. (2013). Early Eocene lizards of the Wasatch Formation near Bitter Creek, Wyoming: diversity and paleoenvironment during an interval of global warming. Bulletin of the Peabody Museum of Natural History, 54, 135-230.

Smith, K. T., Maul, L. C., Flemming, F., Barkai, R., \& Gopher, A. (2016). The microvertebrates of Qesem Cave: a comparison of the two concentrations. Quaternary International, 398, 233-245.

Smith, K. T., \& Scanferla, A. (2016). Fossil snake preserving three trophic levels and evidence for an ontogenetic dietary shift. Palaeobiodiversity and Palaeoenvironments, 96, 589-599.

Smith, K. T., Schaal, S. F. K., \& Habersetzer, J. (2018). Messel: an ancient greenhouse ecosystem. Stuttgart: Schweizerbart. 
Speybroeck, J., Beukema, W., Bok, B., \& Van der Voort, J. (2016). Field guide to the amphibians and reptiles of Britain and Europe. London: Bloomsbury Publishing.

Swinton, W. E. (1939). A new Triassic rhynchocephalian from Gloucestershire. Annals and Magazine of Natural History: Zoology, Botany, and Geology, 4, 591-594.

Talavera, R. R., \& Sanchíz, B. (1983). Restos holocénicos de Camaleón común, Chamaeleo chamaeleon (L.) de Málaga. Boletín de la Real Sociedad Española de Historia Natural, Sección Geológica, 81, 81-84.

Tempfer, P. M. (2003). Amphibians and reptiles of the Karpatian Central Paratethys. In R. Brzobohatý, I. Cicha, M. Kováč, \& F. Rögl (Eds.), The Karpatian-a Lower Miocene Stage of the Central Paratethys (pp. 285-291). Brno: Masarykova Univerzita v Brně.

Tempfer, P. M. (2005). The herpetofauna (Amphibia: Caudata, Anura; Reptilia: Scleroglossa) of the upper Miocene locality Kohfidisch (Burgenland, Austria). Beiträge zur Paläontologie, 29, 145-253.

Tschopp, E., Villa, A., Camaiti, M., Ferro, L., Tuveri, C., Rook, L., et al. (2018). The first fossils of Timon (Squamata: Lacertinae) from Sardinia (Italy) and potential causes for its local extinction in the Pleistocene. Zoological Journal of the Linnean Society, https://doi.org/10.1093/zoolinnean/zly003

Uetz, P., Freed, P., \& Hošek, J. (Eds.). The Reptile Database, http:// www.reptile-database.org, accessed April 2018.

Venczel, M. (2006). Lizards from the late Miocene of Polgárdi (WHungary). Nymphaea: Folia Naturae Bihariae, 33, 25-38.

Venczel, M., \& Hír, J. (2013). Amphibians and squamates from the Miocene of Felsötárkány Basin, N-Hungary. Palaeontographica. Abt. A: Palaeozoology - Stratigraphy, 300, 117-158.

Venczel, M., \& Sanchiz, B. (2006). Lower Miocene amphibians and reptiles from Oschiri (Sardinia, Italy). Hantkeniana, 5, 72-75.

Venczel, M., \& Ştiucă, E. (2008). Late middle Miocene amphibians and squamate reptiles from Tauţ, Romania. Geodiversitas, 30, $731-763$

Vigne, J.-D., Bailon, S., \& Cuisin, J. (1997). Biostratigraphy of amphibians, reptiles, birds and mammals in Corsica and the role of man in the Holocene faunal turnover. Anthropozoologica, 25(26), 587-604.

Vigne, J.-D., Bailon, S., Cuisin, J., \& Desse-Berset, N. (2002). Sensibilité des microvertébrés aux fluctiations hygrométriques tardilaciaires et holocènes: deux séquences en zone méditerranéenne humide (Grítulu et Monte di Tuda, Haut-Corse). In J.P. Bravard \& M. Magny (Eds.), Histoire des rivières et des lacs de Lascaux à nos jours (pp. 269-277). Paris: Errance.

Vijaya, X., \& Prasad, G. V. R. (2001). Age of the Kota formation, Pranhita-Godavari Valley, India: a palynological approach. Journal of the Palaeontological Society of India, 46, 77-93.

Villa, A., Blain, H.-A., \& Delfino, M. (2018a). The Early Pleistocene herpetofauna of Rivoli Veronese (Northern Italy) as evidence for humid and forested glacial phases in the Gelasian of Southern Alps. Palaeogeography, Palaeoclimatology, Palaeoecology, 490, 393-403.

Villa, A., Blain, H.-A., Van Den Hoek Ostende, L. W., \& Delfino, M. (2018b). Fossil amphibians and reptiles from Tegelen (Province of Limburg) and the early Pleistocene palaeoclimate of The Netherlands. Quaternary Science Reviews, 187, 203-219.

Villa, A., Bon, M., \& Delfino, M. (2018c). Trapped in a roman well: amphibians and reptiles from Tenuta Zuccarello near Marcon, Venice, Italy. Historical Biology. https://doi.org/10.1080/ 08912963.2018.1470170.

Villa, A., Daza, J. D., Bauer, A. M., \& Delfino, M. (2018d). Comparative cranial osteology of European gekkotans (Reptilia, Squamata). Zoological Journal of the Linnean Society. https:// doi.org/10.1093/zoolinnean/zlx104.

Villa, A., \& Delfino, M. (2017). Southern Germany: an early to middle Miocene lizard melting pot? Zitteliana, 91, 93.

Villa, A., Kirchner, M., Alba, D. M., Bernardini, F., Bolet, A., Luján, À. H., et al. (2017b). Comparative cranial osteology of extant and extinct Blanus (Squamata, Amphisbaenia). In M. Menegon, A. Rodriguez-Prieto, \& M. C. Deflorian (Eds.), Atti-XI Congresso Nazionale della Societas Herpetologica Italica. Trento, 22-25 settembre 2016 (329-333). Pescara: Ianieri Edizioni.

Villa, A., Kosma, R., Čerňanský, A., \& Delfino, M. (2018e). Taxonomical assessment of 'Bavaricordylus' Kosma, 2004 (Reptilia, Squamata). Journal of Vertebrate Paleontology. https://doi.org/10.1080/02724634.2018.1487844.

Villa, A., Rook, L., Sami, M., \& Delfino, M. (2016). Amphibians and reptiles from Cava Monticino (Ravenna, Italy) in the frame of the late Miocene Italian herpetofaunas. In L. Rook, S. Bartolini, \& E. Ghezzo (Eds.), Paleodays 2016. La Società Paleontologica Italiana a Faenza. XVI riunione annuale SPI, Faenza (82). Torino: Centro Stampa/Regione Piemonte.

Villa, A., Tschopp, E., Georgalis, G. L., \& Delfino, M. (2017a). Osteology, fossil record and palaeodiversity of the European lizards. Amphibia-Reptilia, 38, 79-88.

Vitt, L. J., \& Caldwell, J. P. (2009). Herpetology (3rd ed.). Burlington: Academic Press.

Weithofer, A. (1888). Beiträge zur Kenntniss der Fauna von Pikermi bei Athen. Beiträge Paläontologie Österreich-Ungarns, 6, 225-292.

Whiteside, D. I. (1986). The head skeleton of the Rhaetian sphenodontid Diphydontosaurus avonis gen. et sp. nov. and the modernizing of a living fossil. Philosophical Transactions of the Royal Society of London. Series B, Biological Sciences, 312, 379-430.

Zerova, G. A., \& Chkhikvadze, V. M. (1986). Neogene varanids of the URSS. In Z. Rocek (Ed.), Studies in Herpetology (pp. 689-694). Prague: Societas Herpetologica Europaea.

Zittel, K. (1889). Handbuch der Paläontologie. Munich: R. Oldenbourg. 